Aus der Klinik für Zahnärztliche Prothetik

(Prof. Dr. med. dent. R. Bürgers)

im Zentrum Zahn-, Mund- und Kieferheilkunde

der Medizinischen Fakultät der Universität Göttingen

\title{
Gewinnung und Charakterisierung von humanen Zementoblasten
}

\author{
INAUGURAL-DISSERTATION \\ zur Erlangung des Doktorgrades \\ für Zahnheilkunde \\ der Medizinischen Fakultät der \\ Georg-August-Universität zu Göttingen
}

vorgelegt von

Katharina Bernhardt

aus

Tula (Russland)

Göttingen 2017 
Dekan:

Prof. Dr. rer. nat. H. K. Kroemer

\section{Betreuungsausschuss}

Betreuer/in:

Prof. Dr. med. N. Miosge

Ko-Betreuer/in:

Prof. Dr. med. H. Siggelkow

\section{Prüfungskommission}

Referent/in:

Prof. Dr. med. N. Miosge

Ko-Referent/in:

Prof. Dr. med. H. Siggelkow

Datum der mündlichen Prüfung:

14.05.2018 
Hiermit erkläre ich, die Dissertation mit dem Titel "Gewinnung und Charakterisierung humaner Zementoblasten" eigenständig angefertigt und keine anderen als die von mir angegebenen Quellen und Hilfsmittel verwendet zu haben.

Göttingen, den

(Unterschrift) 


\section{Inhaltsverzeichnis}

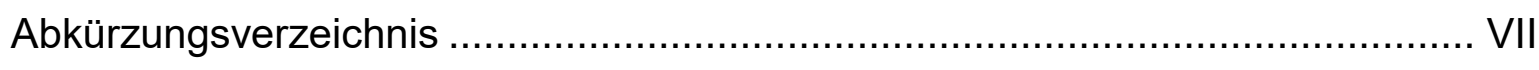

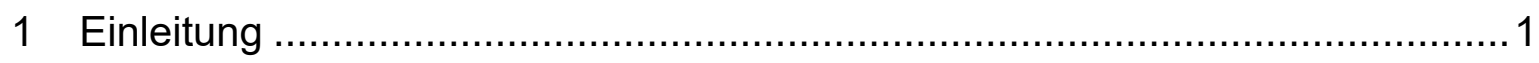

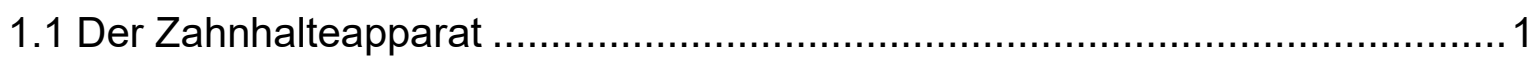

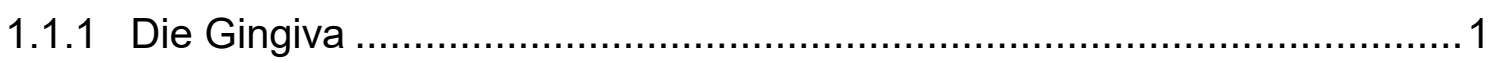

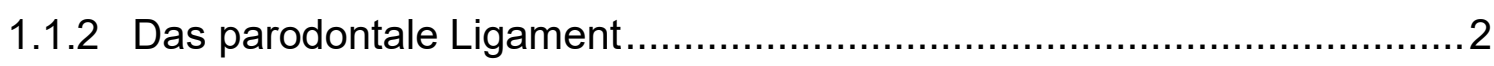

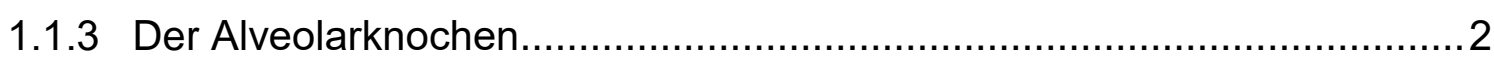

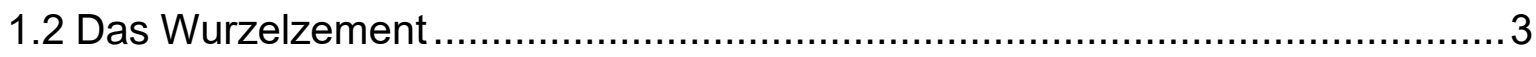

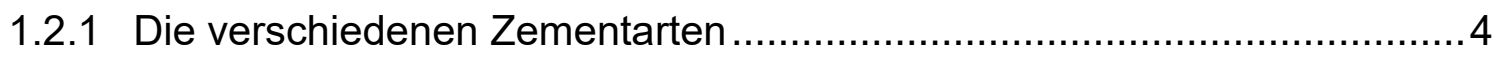

1.2.2 Zementogenese, Bildung des Wurzelzementes................................. 7

1.2.3 Zelluläre Bestandteile des Zementes ........................................ 8

1.3 Immortalisierte Zementoblasten in vitro und in vivo ................................. 10

1.4 Biochemie des Wurzelzementes ..................................................... 11

1.4.1 Molekularbiologische Aspekte der Zementogenese........................... 11

1.4.2 Zusammensetzung der Zement-Matrix .......................................... 14

1.4.3 Kollagene der Zement-Matrix................................................. 14

1.4.4 Nicht-kollagene Proteine der Zement-Matrix................................. 15

1.4.5 Schmelzassoziierte Proteine der Zement-Matrix ............................... 18

1.4.6 Zement-spezifische Proteine der Zement-Matrix ............................. 19

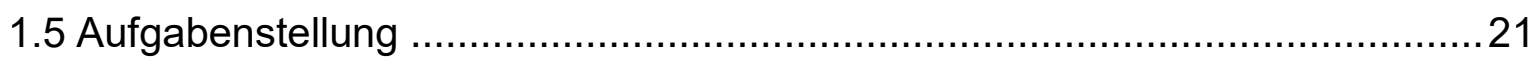

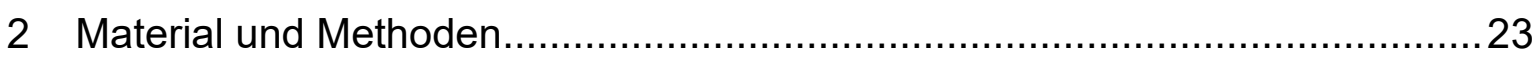

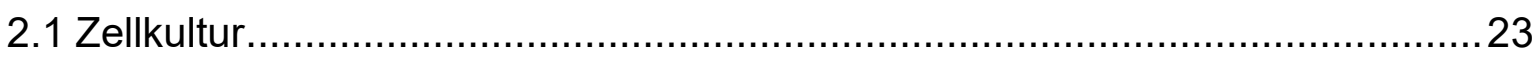

2.1.2 Herkunft und Isolierung von Zementoblasten ................................. 23

2.1.3 Kultivierung der Zementoblasten ............................................... 23

2.1.4 Passagieren der Zementoblasten .............................................. 24

2.2 Quantitative real-time Polymerase-Chain-Reaction .................................. 25

2.2.1 Allgemeines zur Methode ....................................................... 25

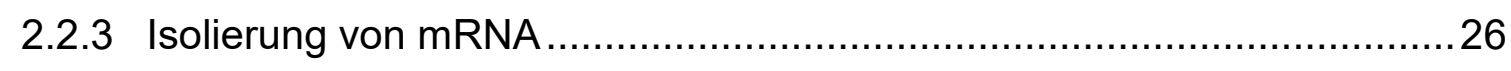

2.2.4 Umschreibung von mRNA in cDNA ............................................. 27 


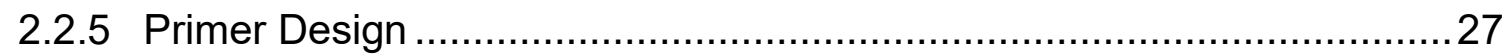

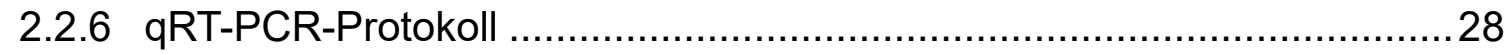

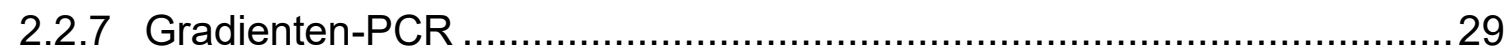

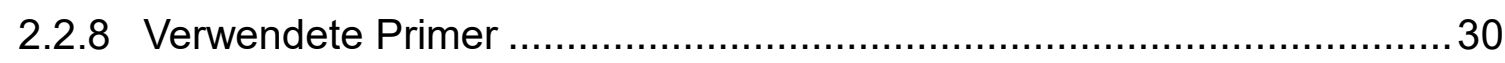

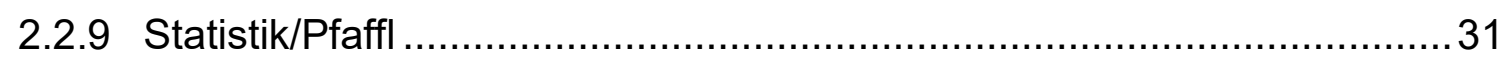

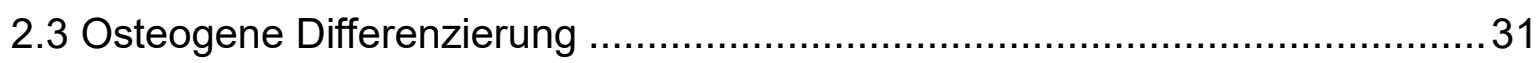

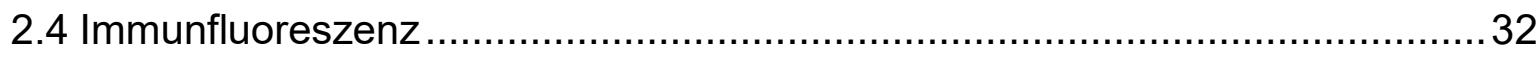

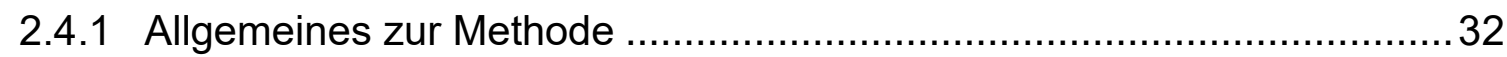

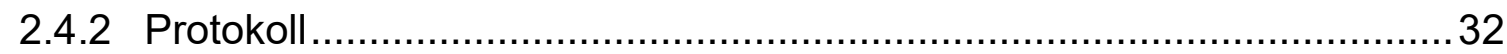

2.4.3 Verwendete primäre und sekundäre Antikörper ....................................34

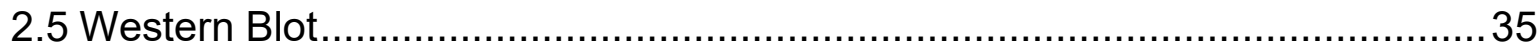

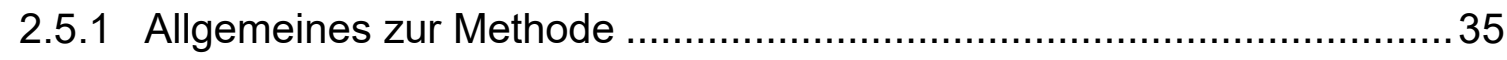

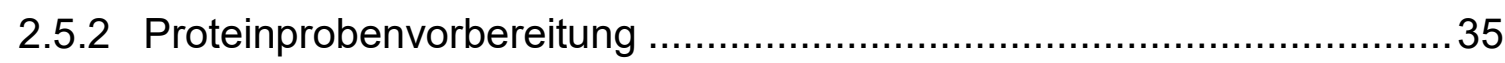

2.5.3 Polyacrylamid-Gel-Herstellung für SDS-PAGE .................................. 36

2.5.4 Natriumdodecylsulfat-Polyacrylamidgelelektrophorese/SDS-PAGE ........38

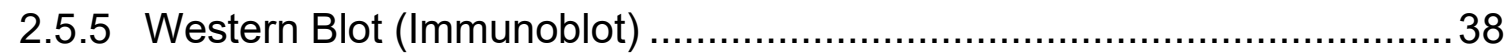

2.5.6 Proteindetektion............................................................................. 39

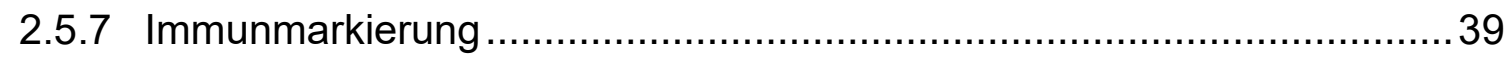

2.5.8 Verwendete Antikörper ..................................................................... 41

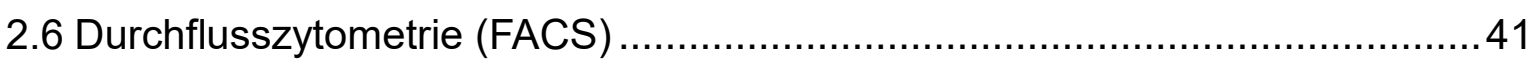

2.6.1 Eingesetzte Antikörper ............................................................... 42

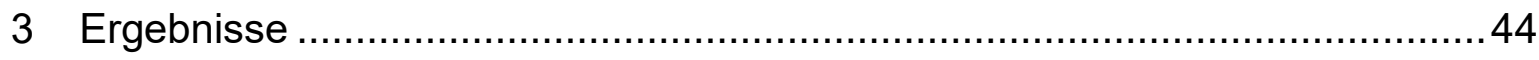

3.1 Primäre humane Zementoblasten ............................................................ 44

3.2 Nachweis über die Immortalisierung der Zementoblasten............................4 44

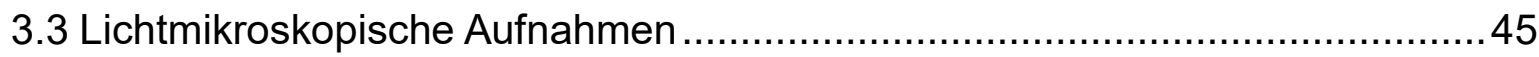

3.3.1 Lichtmikroskopische Aufnahmen undifferenzierter Zementoblasten ........46

3.3.2 Lichtmikroskopische Aufnahmen osteogen differenzierter

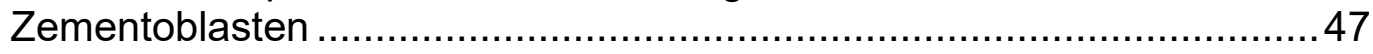

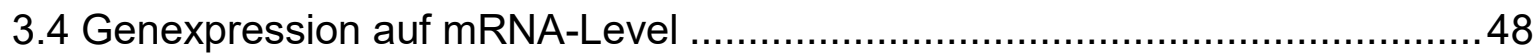

3.4.1 Relatives mRNA-Level von Zementoblasten .................................... 49

3.4.2 Relatives mRNA-Level osteogen differenzierter Zementoblasten............51

3.5 Ergebnisse der Western Blots .............................................................52 


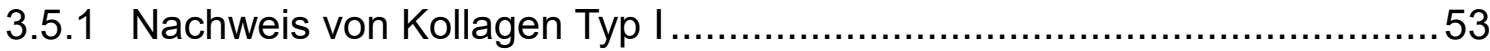

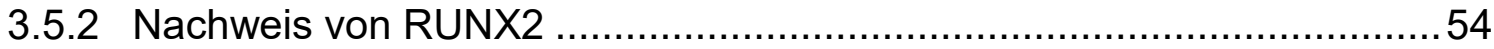

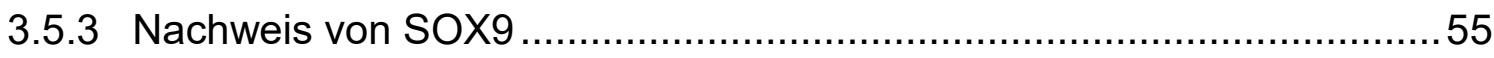

3.6 Immunzytochemischer Nachweis verschiedener Proteine ..............................56

3.7 Nachweis verschiedener intrazellulärer Proteine durch die FACS-Analyse.....61

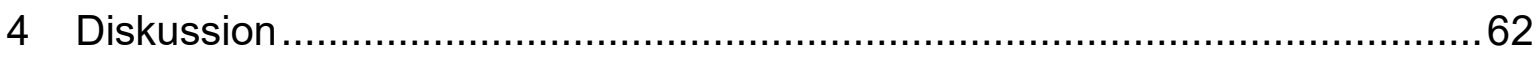

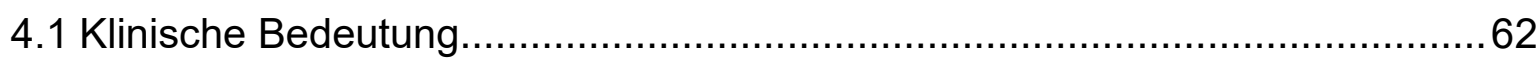

4.2 Diskussion der Expression der Kollagene Typ I und III .................................63

4.3 Proteoglykane als Bestandteile der extrazellulären Matrix im humanen

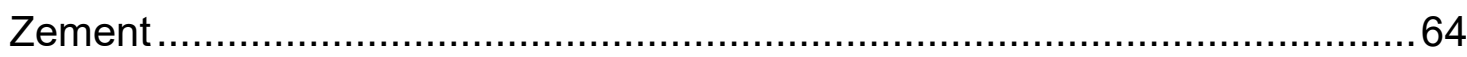

4.3 Die beiden Transkriptionsfaktoren RUNX2 und SOX9 ...............................65

4.4 Diskussion über die typischen Matrix-Proteine Osteocalcin, Bone Sialoprotein, Osteopontin und Osteonektin......................................... 67

4.5 Diskussion über den Nachweis von VEGF im Zement ...................................71

4.6 Diskussion über den Nachweis von RANK/RANKL, Sklerostin und der

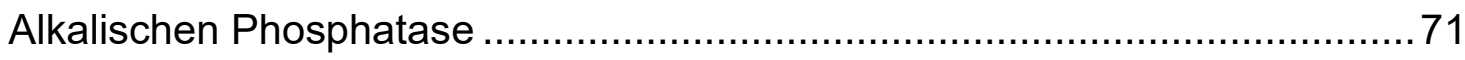

4.7 Die Rolle von CP-23 als spezifischer Zementmarker .................................73

4.8 Diskussion über die Bedeutung einer Eigenständigkeit der Zelllinie der

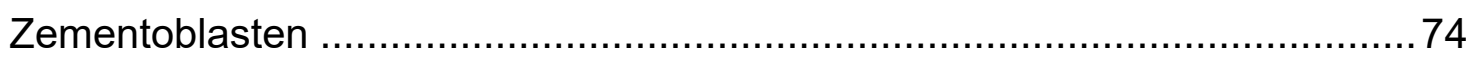

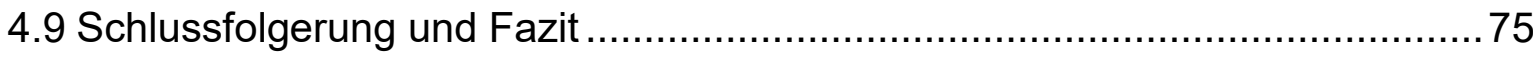

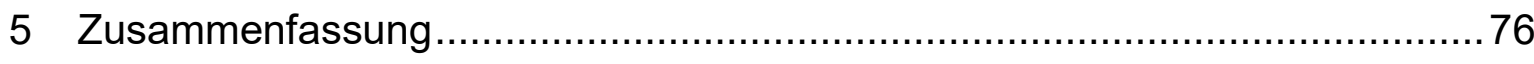

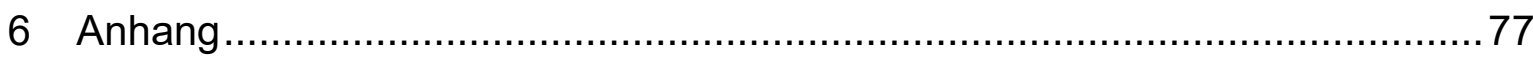

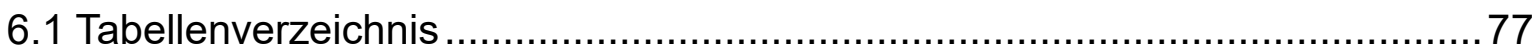

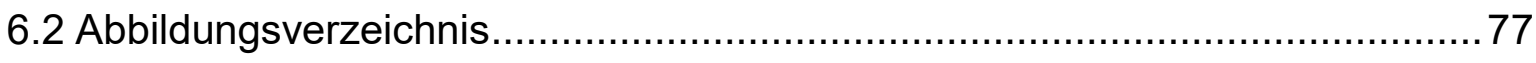

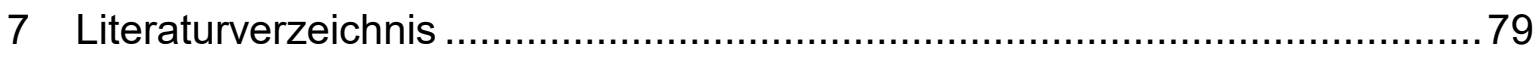




\section{Abkürzungsverzeichnis}

Akt

ALP

APS

HRP

BALP

BMP

BP

BSA

BSP

CAP

Cbfa1

CCD

cDNA

CP-23

CPC

CT

DAPI

DG

DMEM

DMP1

ERK

EZM

FACS
Proteinkinase B, eine Serin/Threonin-Kinase

Alkalische Phosphatase

Ammoniumperoxidsulfat

horseraddish peroxidase

bone alkaline phosphatase

bone morphogenetic protein

Basenpaar

bovines Serumalbumin

bone sialoprotein

cementum-derived attachment protein

corebinding factor alpha 1

Cleidocraniale Dysplasie

komplementäre DNA

cementum protein 1

chondrogene Progenitorzelle

threshold cycle

4', 6-Diamidin-2-phenylindiol

Deckgläschen

Dulbecco's Modified Eagle's Medium

dentin matrix acidic phosphoprotein 1

extracellular-signal regulated kinase

extrazelluläre Matrix

fluorescence activated cell sorting 
FCS

GAG

GAPDH

HMG

HERS

hTERT

MAPK

MMP

mRNA

mTOR

OB

OPG

PAGE

PBS

PCR

qRT-PCR

PDL

$P G$

PVDF

PTHrP

RANKL

RGD

RUNX2

SDS

SOST

sox9 fetales Kälberserum

Glykosaminoglykane

Glycerinaldehyd-3-phosphat-Dehydrogenase

high mobility group

Hertwig-Epithelscheide

human telomerase reverse transcriptase

mitogen-activated protein kinases

bone morphogenetic protein

messenger RNA

mechanistic target of rapamycin

Osteoblasten

Osteoprotegrin

Polyacrylamidgelelektrophorese

phosphate buffered saline

polymerase chain reaction, Polymerasekettenreaktion

quantitative real-time PCR, quantitative Echtzeit-PCR

Parodontalligament

Proteoglykane

Polyvinylidenfluorid

parathormon related-protein

receptor activator of NF-kB ligand

Sequenz Arginin, Glycin und Asparaginsäure

runt-related transcription factor 2

Natriumdodecylsulfat

Sklerostin

SRY (sex determining region Y)-box 9 
Abkürzungsverzeichnis

SPARK

secreted protein acid and rich in cysteine

TBS-T

tris-buffered saline and tween 20

TEMED

$\mathrm{N}, \mathrm{N}, \mathrm{N}^{\prime}, \mathrm{N}^{\prime}$ - Tetramethylethylendiamin

VEGF

vascular endothelial growth factor

Wnt

wingless integration 1

ZB

Zementoblasten 


\section{Einleitung}

In der vorliegenden Arbeit werden humane Zementoblasten, die nach Zahnextraktionen gewonnen wurden, kultiviert und mit unterschiedlichen Methoden untersucht und charakterisiert. Das Wurzelzement stellt einen wichtigen Bestandteil des Zahnhalteapparates dar, weshalb im Folgenden zunächst auf seine einzelnen Bestandteile eingegangen wird.

\subsection{Der Zahnhalteapparat}

Der Zahnhalteapparat, auch Parodontium genannt, wird in vier Strukturkomponenten unterteilt: die Gingiva, das parodontale Ligament (PDL), der Alveolarknochen und das Zement. Jede dieser Komponenten hat ihre spezielle Struktur, über die ihre Funktion definiert wird (Nanci und Bosshardt 2006). Neben der Hauptaufgabe, der elastischen Verankerung des Zahnes im Kieferknochen, stellen die Dämpfung der Kaukräfte, die Aufnahme von taktilen Reizen und letztendlich auch die Ausbildung einer Barriere zur Umwelt und die damit verbundene immunologische Funktion mit Schutz vor Infektionen weitere wichtige Aufgaben dar (Conrads 2010).

\subsubsection{Die Gingiva}

Von den vier Komponenten des Zahnhalteapparates ist einzig die Gingiva klinisch sichtbar (Hassell 1993). Sie bedeckt im gesunden Zustand den Alveolarknochen und die Zahnwurzel (Hassell 1993; Bartold et al. 2000). Topografisch wird die Gingiva in unterschiedliche Zonen unterteilt: freie Gingiva, befestigte Gingiva und interdentale Gingiva (Orban 1948).

Als freie Gingiva wird der Teil bezeichnet, der die Zahnoberfläche kragenförmig umgibt, koronal der Schmelz-Zement-Grenze liegt und bis zur gingivalen Furche reicht, die eine flache Einkerbung auf der faszialen Gingivaoberfläche darstellt (Orban 1948; Conrads 2010). Die befestigte Gingiva erstreckt sich koronal der mukogingivalen Grenze und ist durch Kollagenfasern mit dem darunter liegenden Pe- 
riost verbunden. Die interdentale Gingiva bzw. die Interdentalpapille füllt den Approximalraum zweier benachbarter Zähne aus und wird durch die freie Gingiva miteinander verbunden (Hassell 1993).

Die Epithelien der Gingiva können in das orale Gingivaepithel, das orale Sulkusepithel und das Saumepithel eingeteilt werden.

\subsubsection{Das parodontale Ligament}

Das PDL ist ein spezialisiertes Bindegewebe, das sich zwischen dem Wurzelzement und dem Alveolarknochen befindet (Nanci und Bosshardt 2006). Seine Fasern bilden ein festes Netzwerk, verlaufen von der Alveolarwand und inserieren als Sharpey-Fasern im Wurzelzement. Das PDL schafft eine Verbindung zwischen Zahn und Alveolarknochen, die Verankerung, Schutz, Übertragung und Regelung sensorischer Reize für das mastikatorische System (Kausystem) vermittelt (Beertsen et al. 1997). Während der extrazelluläre Teil überwiegend aus Kollagenfaserbündeln besteht, finden sich im zellulären Teil Fibroblasten, Osteoklasten und Osteoblasten, Mallassezsche Epithelreste, Monozyten und Makrophagen, Zementoblasten und Odontoblasten sowie undifferenzierte Mesenchymzellen (Nanci und Bosshardt 2006). Dabei bilden die Fibroblasten die überwiegende Population des zellulären PDL-Anteils (Bevelander und Nakahara 1968; Lekic et al. 1997).

Zur parodontalen Wundheilung steuert das PDL nicht nur Zellen für eigene Reparaturvorgänge bei, sondern auch für den Wiederaufbau von Knochen und Wurzelzement (Karring et al. 1993; Beertsen et al. 1997). Auch Zellen mit Stammzellcharakter, die das Potenzial haben, Zement und PDL-ähnliches Gewebe in vivo zu generieren, wurden aus humanem PDL isoliert (Seo et al. 2004) und spielen sowohl für die Knochen- als auch für die Zementregeneration eine entscheidende Rolle (Beertsen et al. 1997).

\subsubsection{Der Alveolarknochen}

Der Alveolarfortsatz bildet den Teil von Ober- und Unterkiefer, in den die Zähne eingelassen sind (Hellwig et al. 2010) und sorgt für eine knöcherne Verankerung des Zahnes (Cho und Garant 2000). Obwohl der Alveolarknochen im Wesentlichen mit 
anderen Knochengeweben im Körper zu vergleichen ist, unterliegt er einem ständigen, kontinuierlichen und schnellen Remodellierungsprozess (Sodek und McKee 2000). Während der Alveolarknochen außen aus Kompakta-Kortikalsplatten (bukkal, lingual, palatinal) besteht, findet sich zentral Spongiosa. Zudem werden die Alveolen ebenfalls von Knochen ausgekleidet (Nanci und Bosshardt 2006).

Der Alveolarknochen, auch oft als Bündelknochen (bundle bone) bezeichnet, besteht außen, d.h. dem PDL zugewandt, aus kollagenen Faserbündeln. Diese sogenannten Sharpey-Fasern werden von den Fibroblasten des PDL produziert und inserieren in den Alveolarknochen. Das innere Fasernetzwerk ist im Vergleich zum äußeren Fasernetzwerk deutlich weitmaschiger und wird von Osteoblasten synthetisiert (Saffar et al. 1997). Strukturbiologisch ist der Alveolarknochen ein lamellärer Knochen, der zu etwa 60 \% aus anorganischem Material, hauptsächlich Hydroxylapatit besteht (Conrads 2010). Die vorherrschende Komponente der organischen Matrix ist Kollagen Typ I (Rao et al. 1979), aber auch Kollagen Typ III, V, und VI können im Alveolarknochen nachgewiesen werden (Wang et al. 1980; Lukinmaa und Waltimo 1992). Für den Alveolarknochen typische, nicht kollagene Proteine sind: Osteocalcin (Sodek und McKee 2000), Osteonektin (Termine et al. 1981), Osteopontin (Bronckers et al. 1994), Bone Sialoprotein (BSP) (Chen et al. 1993), Biglykan und Dekorin (Bianco et al. 1990). Während die Osteoblasten für die Knochensynthese verantwortlich sind, übernehmen die Osteozyten die resorptiven Vorgänge. Dabei stellen die Osteoblasten zunächst eine nicht mineralisierte Matrix her, das sogenannte Osteoid. Nach der Mineralisation des Osteoids differenzieren sich die Osteoblasten zu Osteozyten und verbleiben als solche in den Lakunen (FranzOdendaal et al. 2006).

\subsection{Das Wurzelzement}

Das humane Wurzelzement wurde 1835 zum ersten Mal von Studenten des Physiologen Jan Evangelista Purkinje (Universität Prag) entdeckt und erforscht (Denton 1941). Das dentale Wurzelzement wird von den Zementoblasten gebildet und bedeckt den koronalen Anteil, den apikalen Bereich und die Furkation der Wurzel (Samandari und Mai 1995). Es besteht aus einer 20-200 $\mu \mathrm{m}$ dicken, mineralisierten Matrix und ist ein avaskuläres, alymphatisches und nicht innerviertes Gewebe, wel- 
ches ungleichmäßig von Lakunen, in denen Zementozyten enthalten sind, durchsetzt ist (Mariotti 1993). Die Zähne sind nicht starr im Alveolarknochen befestigt, sondern über die Sharpey-Fasern des PDL, die sowohl in Knochen als auch in Zement inserieren, federnd verankert. Deshalb gehört das Zement sowohl zum Zahn selber als auch zum Parodontium. Diese Verankerung der Kollagenfasern des PDL an der Wurzeloberfläche gehört zu den Hauptaufgaben des Zementes. Des Weiteren besitzt Zement adaptive und reparative Fähigkeiten (Bosshardt und Selvig 1997). Histologische Untersuchungen haben gezeigt, dass dentales Zement dem Knochen sehr ähnlich ist. Es besteht sowohl aus einer anorganischen als auch aus einer organischen Matrix (Selvig 1965). Auf weitere Einzelheiten und den genauen strukturellen und biochemischen Aufbau des Zementes wird im Folgenden näher eingegangen.

\subsubsection{Die verschiedenen Zementarten}

Je nach Zusammensetzung der kollagenen Matrix, dem Gehalt an Zellen und Fasern werden in der Literatur folgende unterschiedliche Zementarten beschrieben: azelluläres afibrilläres Zement, azelluläres Fremdfaserzement, zelluläres und azelluläres Eigenfaserzement, zelluläres Gemischfaserzement, Zwischenzement und Zementoid (Radlanski 2011).

\section{Azelluläres afibrilläres Zement}

Das azelluläre afibrilläre Zement besteht aus einer mineralisierten Matrix, die ähnlich der des azellulären Fremdfaserzementes scheint, enthält jedoch weder kollagene Fasern noch eingelagerte Zellen. Der Mangel an Kollagenfasern weist darauf hin, dass diese Zementart keine Funktion für die Zahnverankerung besitzt. Es bedeckt kleine Schmelzbereiche, vor allem nahe und entlang der Schmelz-ZementGrenze (Bosshardt und Selvig 1997).

\section{Azelluläres Fremdfaserzement}

Azelluläres Fremdfaserzement findet sich vor allem im zervikalen und mittleren Wurzelbereich (Bosshardt und Selvig 1997). Es wird sehr langsam gebildet und wird als 
azellulär betrachtet, weil die Zellen, von denen es stammt, an seiner Oberfläche verbleiben (Nanci und Bosshardt 2006). Die Synthese und Entwicklung des azellulären Fremdfaserzementes findet vor allem während des Zahndurchbruchs statt, noch vor der Organisation und Ausrichtung des parodontalen Faserapparates und auch bevor jegliche andere Zementart gebildet wird (Bosshardt und Schroeder 1991a; Bosshardt und Schroeder 1991b). Azelluläres Fremdfaserzement bedeckt 40 bis $70 \%$ der Wurzeloberfläche und besteht aus Kollagenfasern und Glykosaminoglykanen (GAG) (Cho und Garant 2000). Die außerordentlich hohe Dichte an Kollagenfasern, die als Sharpey-Fasern in das azelluläre Fremdfaserzement inserieren, spricht für die wesentliche Funktion dieser Zementart, den Zahn in der Alveole zu verankern (Bosshardt und Selvig 1997). Die Dickenzunahme des azellulären Fremdfaserzementes findet - wenn auch äußerst langsam - ein Leben lang statt (Sequeira et al. 1992). Zuwachslinien, sogenannte Salter-Linien, die parallel zur Wurzeloberfläche verlaufen, deuten auf eine schichtweise erfolgende Zementanlagerung hin (Berkovitz et al. 2009).

\section{Zelluläres und azelluläres Eigenfaserzement}

Zelluläres Eigenfaserzement wird von Zementoblasten gebildet, die intrinsische (zelleigene) Fasern sezernieren. Die Bildung dieser Zementart beginnt auf der Dentinoberfläche, nachdem sich die Hertwig-Epithelscheide (HERS) aufgelöst hat (Bosshardt und Schroeder 1992). Von der Dentinoberfläche entfernte Zementoblasten mauern sich selber ein, indem sie Bestandteile der Zement-Matrix an diversen umgebenden Stellen abscheiden. Die in einer solchen Lakune sitzenden Zellen werden als Zementozyten, die sich aus Zementoblasten differenziert haben, bezeichnet (Bosshardt und Selvig 1997). Bei der Zahnverankerung spielt das zelluläre Eigenfaserzement keine Rolle, da keine Sharpey-Fasern existieren und die intrinsischen Kollagenfasern keine Verbindung zum PDL zeigen (Bosshardt 2005). Zelluläres Eigenfaserzement entsteht sowohl prä- als auch posteruptiv und findet sich im apikalen Bereich und in Wurzelfurkationen (Bosshardt und Schroeder 1992). Nur zelluläres Eigenfaserzement ist in der Lage, Resorptionsdefekte an der Wurzel in relativ kurzer Zeit zu reparieren (Bosshardt und Selvig 1997). In seltenen Fällen wird das Eigenfaserzement und die Abscheidung seiner Matrix so gebildet, dass Zemen- 
tozyten völlig fehlen. Dieses spezielle Gewebe besteht aus dicht gebündelten Kollagenfasern und wird azelluläres Eigenfaserzement genannt (Bosshardt und Selvig 1997).

\section{Zelluläres Gemischfaserzement}

Das zelluläre Gemischfaserzement ist an sich keine eigene Zementart, sondern ein Mischprodukt, dass dadurch entsteht, dass sich abwechselnd Lagen von zellulärem bzw. azellulärem Eigenfaserzement und azellulärem Fremdfaserzement bilden und anlagern. Es kommt in bestimmten Bereichen der Wurzel regelmäßig vor, weshalb der eigene Terminus durchaus berechtigt ist. Die Schichten der unterschiedlichen Zementarten können sich sowohl abwechseln als auch miteinander verstrickt sein. Auch hier wandeln sich Zementoblasten, die von Zement-Matrix umhüllt sind, in Zementozyten um (Radlanski 2011). Ca. 10 bis $40 \%$ der Wurzellänge sind vom zellulären Gemischfaserzement bedeckt (Schroeder 1988). Die Dicke des Zementes nimmt kontinuierlich mit dem Lebensalter zu (Zander und Hurzeler 1958; Azaz et al. 1974).

\section{Zwischenzement}

Zwischenzement (intermediate cementum) wurde von vielen Autoren beschrieben und gilt als fünfte eigenständige Zementart (el Mostehy und Stallard 1968; AmstadJossi und Oksche 1986). Einerseits ist das Zwischenzement als eine Zwischenschicht, zwischen Wurzeldentin und zellulärem Gemischfaserzement zu verstehen (Radlanski 2011). Andererseits ist diese Zwischenschicht nicht wirklich eigenständig (Garant 2003), sondern stellt vielmehr eine Grenzzone zwischen Zement und Dentin dar (Schroeder 1992; Bosshardt und Schroeder 1994; Bosshardt und Selvig 1997).

\section{Zementoid}

Beim Zementoid handelt es sich um eine ca. 3 bis $8 \mu \mathrm{m}$ dicke Zementschicht, die dem azellulären Fremdfaserzement außen aufliegt und in der sich Zementoblasten befinden können (Hellwig et al. 2010). 


\subsubsection{Zementogenese, Bildung des Wurzelzementes}

Ein Zahnkeim, aus dem sich später ein Zahn entwickelt, besteht grundsätzlich aus dem Schmelzorgan, der Zahnpapille und dem Zahnsäckchen. Die Bildung des Wurzelzementes ist eng verknüpft mit der Ausbildung der Zahnwurzel. An der Ausbildung der Zahnwurzel sind unterschiedliche Strukturkomponenten der Zahnanlage, bzw. des Zahnkeimes beteiligt. Von besonderer Bedeutung ist vor allem das innere und äußere Schmelzepithel des Schmelzorganes, das für die Bildung der HERS verantwortlich ist. Nachdem die Kronenbildung abgeschlossen ist, liegen sich inneres und äußeres Schmelzepithel gegenüber. Diese Duplikatur bildet die zervikale Schlinge, aus der später die HERS entsteht. Von den Epithelzellen der HERS wird eine Anlagerungsfläche für die ersten Dentinablagerungen an der Wurzel gebildet. Die Wurzelbildung schreitet voran, indem die HERS weiter Richtung apikal wandert (Radlanski 2011). Man kann durchaus sagen, dass die Zementbildung wenig erforscht ist. Über die Entwicklung und Differenzierung der Zement-Progenitorzellen ist ebenso wenig bekannt, wie über die Zelldynamik der Zementoblasten während ihrer normalen Entwicklung, ihrer Reparations- und Regenerationsfähigkeit (Bosshardt und Selvig 1997).

In der Literatur sind unterschiedliche Theorieansätze über die Zemententwicklung zu finden, denn schon allein im Hinblick auf die Herkunft der Progenitorzellen gehen Meinungen in der Wissenschaft auseinander. Das klassische Modell der Zementogenese sieht den Ursprung der Zementoblasten im mesenchymalen Gewebe. Nachdem die mesenchymalen Zellen des Zahnsäckchens die Barriere der HERS durchbrechen, differenzieren sie sich zu Zementoblasten und fangen an Zement zu sezernieren (Ten Cate 1969; Lester 1969; Amstad-Jossi und Oksche 1986). Hier geht der Zementbildung eine Dentinablagerung an der sich bildenden Wurzel voraus, wobei die HERS als Leitstruktur dient. Anschließend löst sich die HERS wieder auf, wodurch mesenchymale Zellen des Zahnsäckchens durchbrechen, bzw. einwandern und in Kontakt mit dem Wurzeldentin treten. Die mesenchymalen Zellen differenzieren sich durch diesen Kontaktreiz weiter zu Zementoblasten und bilden Zement (Diekwisch 2001). Neben den Zementoblasten sind auch Zementozyten und PDL-Zellen an der Entwicklung und Bildung beteiligt. Auch sie weisen alle eine ektomesenchymale Herkunft auf (Hammarström et al. 1996; Zeichner-David et al. 2003). Die Wurzelspitzenregion die entsteht, ist reich an Progenitorzellen 
ektomesenchymaler Herkunft, aus denen später Fibroblasten, Präodontoblasten und Präzementoblasten entstehen (Garant 2003). Bis heute ist nicht wirklich bekannt welche Einflüsse notwendig sind, damit sich Zellen des Zahnsäckchens zu Zementoblasten differenzieren (Diekwisch 2001).

Eine andere Theorie geht davon aus, dass Zellen aus dem Zahnsäckchen in einen unmittelbar direkten Kontakt mit dem Wurzeldentin treten (Orban 1944). Möglich wäre, dass es sich um eine Migration der Zellen handelt und man deshalb von einem aktiven Prozess sprechen kann (Cho und Garant 1988). Eine weitere Theorie geht davon aus, dass Zellen direkt aus der HERS zu Zementoblasten werden und somit einen epithelialen Ursprung besitzen (Slavkin und Bringas 1976; Nanci 2008). Die Bedingung hierfür müsste dann eine epithelial-mesenchymale Transformation sein (Nanci 2008; McCauley und Somerman 2012). Es wurde auch darüber debattiert, dass azelluläres Zement einen epithelialen Ursprung und zelluläres Zement einen mesenchymalen Ursprung besitzt (Thomas 1995; Bosshardt 2005).

\subsubsection{Zelluläre Bestandteile des Zementes}

\section{Zementoblasten}

Obwohl die Signifikanz des Zementes für die Regeneration und den reparativen Prozess nach einer parodontalen Erkrankung seit vielen Jahren anerkannt ist, ist wenig über die Zementoblasten, die für die Bildung von Zement verantwortlich sind, bekannt (Saygin et al. 2000).

Zementoblasten sind ca. 8-15 $\mu \mathrm{m}$ große kubische Zellen, die den Osteoblasten ähneln und basophil sind (Bosshardt und Schroeder 1990; Bosshardt und Schroeder 1991a). Ihr runder Zellkern ist euchromatinreich (Furseth 1969; Schroeder 1992). Das Zytoplasma ist reich an Golgi-Apparaten und besitzt ein weitläufiges raues endoplasmatisches Retikulum, welches für die Proteinsynthese unverzichtbar ist (Furseth 1974). Zementoblasten liegen der Zementoberfläche auf und synthetisieren ein Präzement, aus welchem später durch Mineralisation das Zement entsteht (Bosshardt 2005). Zementoblasten, die azelluläres Fremdfaserzement bilden, besitzen lange Fortsätze und ähneln den Fibroblasten. Vermutlich formen sich die Zel- 
len aufgrund der engen Nachbarschaft so aus, in der die Fibroblasten und die desmodontalen Fasern dominieren, da dieser Zementtyp überwiegend aus kollagenen Fasern als Zement besteht (Radlanski 2011). Zementoblasten die Fremdfaserzement produzieren, sezernieren zuerst das Zementoid, welches später ausmineralisiert (Bosshardt 2005).

\section{Zementozyten}

Wenn zelluläres Zement gebildet wird, sezernieren die Zementoblasten eine Schicht unmineralisierter extrazellulärer Matrix (EZM), das Zementoid. Während weiterhin Zementoid gebildet wird, werden einige Zementoblasten in der EZM eingeschlossen, bzw. eingemauert und differenzieren sich zu Zementozyten. Zementozyten bleiben im zellulären Zement, indem es keinen natürlichen Umbauprozess gibt, ein Leben lang eingeschlossen (Zhao et al. 2016b). Lakunen, die in tieferen Bereichen des Wurzelzementes liegen, scheinen oft frei von Zementozyten zu sein (Cheng et al. 1996; Grzesik et al. 2000). Das könnte damit zusammenhängen, dass die kritische Entfernung der einzelnen Zementozyten zueinander unüberwindbar ist und kein nötiger Austausch von Metaboliten untereinander gewährleistet werden kann. Es existiert außerdem kein Beweis dafür, dass Zementozyten eine Funktion bei der Gewebehomöostase spielen (Bosshardt 2005). Während junge Zementozyten noch den Zementoblasten ähneln, reduziert sich mit ihrem Alter die Zahl ihrer Organellen im Plasma (Furseth 1967; Furseth und Johansen 1968). Obwohl Zementozyten alle Zeichen vitaler Zellen aufweisen, ist ihre Stoffwechselaktivität im Vergleich zu Zementoblasten herunterreguliert (Furseth 1969). Basierend auf Studien über das zelluläre Zement in Ratten, Mäusen und Menschen, besetzen Zementozyten, genauso wie Osteozyten, Lakunen und entwickeln zytoplasmatische Fortsätze, so genannte Dendriten, die innerhalb dieses Lakunen-Netzwerkes liegen (Ayasaka et al. 1992; Bosshardt und Schroeder 1992; Yamamoto und Hinrichsen 1993; Scivetti et al. 2007; Cao et al. 2012; Zhao et al. 2016b). Das führt zu der Annahme, dass sie in der Lage sein sollten, miteinander und mit außerhalb liegenden Zellen zu kommunizieren (Zhao et al. 2016b). 


\section{Fibroblasten}

Fibroblasten bilden die Sharpey-Fasern des azellulären Fremdfaserzementes (Bosshardt und Schroeder 1991b). Sie sind in enger Nachbarschaft zu den senkrecht in die Wurzeloberfläche einstrahlenden Kollagenfasern zu finden und gleichen in ihrer Form den Bindegewebsfibroblasten (Radlanski 2011). Sie besitzen eine längliche Form, der Kern ist euchromatinreich (Schroeder 1992) und das Zytoplasma ist reich an Organellen (Bosshardt und Schroeder 1992).

\subsection{Immortalisierte Zementoblasten in vitro und in vivo}

Während die Differenzierung und Herkunft der Osteoblasten umfassend erforscht wurde, ist über die Zementoblasten und ihre Differenzierung nur wenig bekannt. Studien über Zementoblasten sind durch Schwierigkeiten wie die selektive Markierung und das Isolieren dieser Zellpopulation von dem angrenzenden PDL und den Osteoblasten aus dem Alveolarknochen behindert worden (Matthews et al. 2016). Darüber hinaus ist nicht bewiesen, ob Zementoblasten ein eindeutig einzigartiger Zelltyp sind oder ob sie eher als positionierte Osteoblasten betrachtet werden können (MacNeil et al. 1998; Bosshardt 2005; Kitagawa et al. 2006). Es wurden viele Anläufe unternommen, um Zementoblasten aus nicht humanem Gewebe zu gewinnen und zu kultivieren, um sie dann zu charakterisieren (Arzate et al. 1992a; Grzesik et al. 1998; MacNeil et al. 1998; D’Errico et al. 1999). Einer der Gründe dafür, warum es schwierig ist immortalisierte Zelllinien aus normalem Gewebe zu gewinnen ist, dass Zellen aus nicht neoplastischem humanen Gewebe in Kultur eine limitierte Teilungskapazität aufweisen und eine zelluläre Seneszenz erreichen (Shay et al. 1991). Es ist generell akzeptiert, dass im Vergleich zum Gewebe aus Nagern, es überaus schwierig ist humane Zelllinien aus nicht neoplastischem-, oder aus gutartigem Tumorgewebe zu kultivieren (Meek et al. 1977; Macieira-Coelho 1980; Curatolo et al. 1984). Um den genauen Prozess der Proliferation und der Differenzierung von humanen Zementoblasten zu studieren, ist ein Zellmodell unabdingbar. Im Jahr 2006 gelang es einer Forschungsgruppe, eine humane Zementoblasten Linie einzuführen, die mit dem Telomerase-hTERT-Gen transfektioniert wurde. Zwei stabile Klone mit hoher Telomerase Aktivität konnten gewonnen werden, die über 200 Passagen ohne signifikante Wachstumsverzögerung wuchsen. Diese Zelllinie 
wurde auf unterschiedlichste Proteine auf mRNA Level untersucht (Kitagawa et al. 2006). Weitere Untersuchungen basierend auf dieser humanen Zementoblastenlinie sind nicht bekannt.

Ein anderer Autor konnten eine immortalisierte Zementozyten-Zelllinie aus Nagern isolieren und etablieren (Zhao et al. 2016a).

\subsection{Biochemie des Wurzelzementes}

Obwohl Zement schon sehr früh beschrieben wurde, bleibt es auf zellulärer und molekularer Ebene bis heute nur ein dürftig definiertes und erforschtes Gewebe (Saygin et al. 2000). Während die Forschung im Laufe der Jahre demonstriert hat, dass Zement auf histologischer Ebene ein einzigartiges Gewebe ist (Bosshardt und Selvig 1997), ist die Auseinandersetzung mit Proteinen, die von Zement-bildenden Zellen, den Zementoblasten exprimiert werden, nicht auf eine definitive Identifizierung von Zement-spezifischen Proteinen hinausgelaufen (MacNeil et al. 1998). Zement scheint genau diejenigen Faktoren zu enthalten, die mit dem Knochen assoziiert werden und soll entwicklungstechnisch sogar von ähnlichen Faktoren kontrolliert werden (Saygin et al. 2000).

Im Verlauf des weiteren Kapitels soll vor allem auf die molekularen und biochemischen Aspekte sowohl der Zementogenese als auch des Zementes an sich eingegangen werden.

\subsubsection{Molekularbiologische Aspekte der Zementogenese}

Während beispielsweise eine große Menge an Informationen über die Entstehung und Bildung des Knochens existiert, ist vergleichsweise wenig über die Regulationsmechanismen der Zementoblasten und die Regulation ihrer Funktion an sich bekannt (Saygin et al. 2000). Sogenannte BMPs (Bone morphogenetic proteins) sollen regulatorische Funktionen übernehmen (King und Cochran 2002; Berry et al. 2003; Taba et al. 2005). In einem Nagermodell wurde gezeigt, dass BMP-2, BMP-4 und BMP-7 die Differenzierung von Präosteoblasten fördern (Zhu et al. 2004), die in der Literatur auch oft als Vorläufer der Zementoblasten angesehen werden (Nanci 2008; Proff und Römer 2009). Bei der Maus wurde im Bereich des ersten Molaren 
auch BMP-3 von den Zellen des Zahnsäckchens exprimiert, weshalb auch BMP-3 eine Rolle bei der Zementbildung spielen könnte (Aberg et al. 1997). Grundsätzlich kann man sagen, dass Wurzelzement dem Knochen sehr ähnlich ist, weshalb angenommen werden kann, dass auch beim Zement die vom Knochen her bekannten Regulationsmechanismen eine wichtige Rolle spielen (Berry et al. 2003; Bosshardt 2005; Zhao et al. 2016b). Ein Durchbruch in der Knochenforschung, was die therapeutischen Maßnahmen anbelangt, war die Entdeckung des RANK/RANKL/OPGSystems, welches unverzichtbar für die Knochenregulation ist und gleichzeitig die Biologie des Knochens mit der Immunbiologie verbindet (Grcević et al. 2001; Hofbauer und Heufelder 2001). Das System interagiert als Regulationsmechanismus und spielt beim Umbauprozess des Knochens eine entscheidende Rolle. Es unterdrückt sowohl die Entwicklung, als auch die Aktivität der Osteoklasten. Obwohl Zement in menschlichen Zähnen keinen physiologischen Umbauprozessen unterliegt, ist die Wurzelresorption sowohl bei kieferorthopädisch behandelten Zähnen, als auch bei pathologischen Prozessen wie der Parodontitis, ein oft gefundenes Phänomen. In diesem Zusammenhang stellt sich die interessante Frage, ob das RANK/RANKL/OPG-System in Zementoblasten genauso abläuft und arbeitet wie in Osteoblasten (Bosshardt 2005). Die OPG und RANKL-Expression wurde z.B. in PDL-Zellen in vitro gefunden (Hasegawa et al. 2002; Sakata et al. 2002) und auch während physiologischer Wurzelresorption (Lossdörfer et al. 2002a). Ob aber Zementoblasten tatsächlich zu einer Produktion von OPG und RANKL beitragen ist unklar. Trotzdem scheint das RANK/RANKL/OPG-System bei der Regulation der Zementresorption eine Rolle zu spielen (Bosshardt 2005). Die in vivo Regulation von RANKL- und OPG-Expression wurde sowohl in Zementoblasten, als auch in Zementozyten noch nicht umfassend genug erforscht.

Der Transkriptionsfaktor RUNX2 (runt-related transcription factor 2), auch bekannt als Cbfa1 (corebinding factor alpha 1), ist essentiell für die Ausdifferenzierung von Osteoblasten aus ihren Progenitorzellen (Ducy 2000; Karsenty 2000). Seine Expression ist allerdings nicht nur auf Zellen der osteogenen/chondrogenen Linie beschränkt (Bronckers et al. 2001), sondern wurde auch bereits in Odontoblasten, Zellen des Zahnfollikels, PDL-Zellen, Zementoblasten, Zementozyten, dentalen Epithelzellen und in einigen nicht dentalen Zelllinien festgestellt (Bosshardt 2005). Das heißt, die meisten Zellen, die in zellulärem Zement eingemauert sind, exprimieren RUNX2-mRNA und RUNX2-Protein in unterschiedlichem Ausmaß (Bronckers et 
al. 2001). Da Zementoblasten mineralisierende Zellen sind, ist das natürlich kein überraschender Fund (Camilleri und McDonald 2006). Bei der Maus ist während der Zahnentwicklung RUNX2-mRNA sowohl im Mesenchym um die Zahnanlage als auch in der Dentalpapille nachweisbar (D'Souza et al. 1999). Bei Mäusen, bei denen RUNX2 fehlt, entwickelt sich die Zahnanlage nicht weiter und es kommt zu einer Nichtausbildung einer sogenannten Aplasie der betroffenen Zähne (Aberg et al. 2004). Bei der Cleidocranialen Dysplasie (CCD), auch Dysostosis cleidocranialis genannt, ist RUNX2/Cbfa1 von einer Mutation betroffen, und es kommt zu einer Ausbildung eines abnormalen Phänotyps (Mundlos et al. 1997). Die Erkrankung wird autosomal-dominant vererbt und ist charakterisiert durch zahlreiche Missbildungen des Knochens, vor allem auch im Bereich des Schädels (Camilleri und McDonald 2006). Diese sogenannte Haploinsuffizienz von RUNX2/Cbfa1 beeinflusst beim Menschen nicht nur die Knochenbildung, sondern sorgt für die Ausbildung von überschüssigen Prämolaren (Mundlos et al. 1997; Otto et al. 1997). RUNX2 wurde also als essentiell für die Zahnbildung identifiziert (Ducy et al. 1999). Dentale Abnormalität, die bei CCD-Patienten beobachtet wurde (Hitchin 1975; Jensen und Kreiborg 1990), könnte deshalb ein direktes Ergebnis der RUNX2-Störung in Zahn-bildenden Zellen sein. Sowohl azelluläres als auch zelluläres Zement sind in Fällen der CCD fehlerhaft ausgebildet. RUNX2 scheint deshalb auch beim Zement einen regulierenden Mechanismus darzustellen (Camilleri und McDonald 2006).

Ein anderes Molekül, das sich als wichtig erweisen kann, ist das Parathormon-ähnliche Protein (Parathormon related-Protein, PTHrP) (Saygin et al. 2000). Es scheint, dass das PTHrP eine Rolle bei der Regulation früher Stadien der Zahnentwicklung spielt (Philbrick et al. 1998) und somit eine wichtige regulatorische Rolle bei der Zementogenese haben könnte (Ouyang et al. 2000). Es wurde gezeigt, dass Zementoblasten einer Ratte Rezeptoren für PTH/PTHrP (Tenorio und Hughes 1996) und das PTHrP-Gen exprimieren (Beck et al. 1995).

Ein weiteres Protein der EZM ist das DMP1 (dentin matrix acidic phospoprotein 1). DMP1 reguliert die Mineralisation und wurde ursprünglich in Dentin entdeckt. Später wurde allerdings festgestellt, dass es viel umfangreicher und viel höher in Osteozyten exprimiert wird. Aber auch in Zementozyten der Maus wurde DMP1 sowohl in vivo als auch in vitro gefunden (McCauley und Somerman 2012; Zhao et al. 2016a). 
Sklerostin/SOST wird eigentlich von reifen Osteozyten exprimiert und reguliert negativ die Knochenbildung, indem es den Wnt-Signalweg in Osteoblasten hemmt (Zhao et al. 2016b). Es wurde festgestellt, dass auch Zementozyten SOST/Sklerostin in vivo und in vitro exprimieren und somit auch die Aktivität der Zementoblasten regulieren könnten (van Bezooijen et al. 2009; Jäger et al. 2010; Lehnen et al. 2012; Zhao et al. 2016a). Es konnte gezeigt werden, dass der Knockout von SOST in einem Mausmodell zu einer 1,5-fach erhöhten Abscheidung von zellulärem Zement führte (Kuchler et al. 2014).

\subsubsection{Zusammensetzung der Zement-Matrix}

Biochemische Untersuchungen haben gezeigt, dass Zement eine ähnliche chemische Zusammensetzung wie Knochen hat. In etwa zu gleichen Teilen besteht Zement aus Wasser, organischer Matrix und Mineral. Ungefähr $50 \%$ der Zementmasse ist anorganisch und besteht aus Hydroxylapatit-Kristallen. Die organische Matrix enthält vor allem Kollagene und zu einem kleineren Ausmaß Glykoproteine und Proteoglykane (PG) (Bosshardt und Selvig 1997).

Im folgenden Kapitel soll vor allem auf die wichtigsten Komponenten der organischen Matrix eingegangen werden. Primär werden die vorherrschenden Proteine und die als Zementmarker bezeichneten und angesehenen Proteine vorgestellt.

\subsubsection{Kollagene der Zement-Matrix}

Die organische Matrix von Zement besteht hauptsächlich aus Kollagenen. Ähnlich wie in Knochen und dem PDL, wurden die zwei typischen Faser-bildenden Kollagene Typ I und III auch im Zement gefunden (Bosshardt und Selvig 1997). Ungefähr $90 \%$ der organischen Matrix besteht aus Kollagen Typ I und ca. $5 \%$ belaufen sich auf Kollagen Typ III (Christner et al. 1977). Einerseits wurde angenommen, dass die Kollagen-Typ I-Fasern von Kollagen-Typ III-Fasern ummantelt sind (Wang et al. 1980), andererseits konnte auch gezeigt werden, dass Kollagen Typ I scheinbar mit Kollagen Typ III eher in derselben Fibrille vorkommt, als von Kollagen Typ III ummantelt zu sein (Keene et al. 1987; Becker et al. 1991). Die Kollagene sind aus drei alpha-Polypeptidketten, die umeinander gespult sind, aufgebaut und bilden so die klassische Triple-Helix (Hay 1991). Zum einen ist Kollagen Typ I dafür bekannt, Zelladhäsion zu fördern, zum anderen ist es aber auch ein entscheidendes Molekül für 
den Erhalt von Weich- und Hartgewebe, sowohl während der Entwicklung als auch während der Regeneration (Saygin et al. 2000). In den meisten Geweben spielen Kollagene eine wichtige strukturelle und morphogenetische Rolle (Hay 1991). In mineralisiertem Gewebe stellen sie auch eine Art Gerüst für die Mineralkristalle dar (Christoffersen und Landis 1991). Neben Kollagen Typ I und III kommen im Zement auch Kollagen Typ V, VI und XII vor (Bosshardt 2005).

\subsubsection{Nicht-kollagene Proteine der Zement-Matrix}

Es wird angenommen, dass Knochen, Zement und Dentin eine Art Standardset von NCP's (non-collagenous macromolecules) haben und dass die Einzigartigkeit eines Gewebes in der genauen Kombination dieser NCP's liegt (Butler et al. 2003).

\section{Bone Sialoprotein und Osteopontin}

Zement enthält viele nicht-kollagene Proteine, einschließlich einiger sehr wichtiger Phosphoproteine, wie Osteopontin und BSP. BSP-mRNA und BSP-Protein bleiben an der Wurzeloberfläche von Zähnen lokalisiert, während Osteopontin in der PDL Region vorkommt (Macneil et al. 1994; MacNeil et al. 1995a). Beide dieser Proteine sind sauer und besitzen eine gut organisierte Adhäsionsdomäne bestehend aus arginine-glycine-aspartic (RGD)-Sequenzen, die sich auf spezielle Integrin-Rezeptoren richten, welche die Migration und Zelladhäsion fördern (Somerman et al. 1988; Xuan et al. 1994; Denhardt et al. 1995; Xuan et al. 1995). Osteopontin bleibt an die Kollagen-Matrix gebunden und vermittelt durch seine RGD-Sequenzen eine anhaftende Wirkung auf die Zellen (Sodek et al. 2000). BSP hat ebenfalls Zelladhäsion vermittelnde Eigenschaften (Oldberg et al. 1988). Beide Proteine scheinen als Regulatoren für die Hydroxylapatit Kristallkeimbildung und Kristallwachstum eine entscheidende Rolle zu spielen (Arzate et al. 2015). BSP und Osteopontin füllen den interfibrillären Platz aus, weshalb auch im azellulären Fremdfaserzement, welches viel interfirbrillären Raum besitzt, große Mengen beider Proteine lokalisiert wurden (Bosshardt 2005). Es wird angenommen, dass BSP den Prozess der Zementogenese moduliert und in den Prozess der chemischen Affinität, Adhäsion und Differenzierung von Präzementoblasten involviert ist (MacNeil und Somerman 1993; 
Macneil et al. 1994; MacNeil et al. 1995b). Sowohl BSP als auch Osteopontin scheinen außerdem eine Rolle bei der Differenzierung von Zementoblasten-Progenitorzellen in Zementoblasten zu spielen (Saygin et al. 2000).

\section{Osteonektin}

Osteonektin ist ein weiteres glykosyliertes Protein, welches in der EZM von mineralisiertem Gewebe gefunden wird. Es scheint im Mineralisationsprozess eine enge Beziehung zwischen Osteonektin und Kollagen zu existieren. Osteonektin soll für die Kopplung des Minerals an Kollagenfibrillen verantwortlich sein (Termine et al. 1981; Fisher und Termine 1985; Romberg et al. 1985). Das Protein ist 40 kDa groß und zählt zu den ersten Proteinen die aus Knochen isoliert wurden (Termine et al. 1981). Osteonektin besteht aus vier Domänen und besitzt neben einer Kalzium bindenden Seite auch mehrere Stellen mit geringer Affinität zu Kalzium (Engel et al. 1987). Zusätzlich hat Osteonektin die Fähigkeit das Kristallwachstum von Hydroxylapatit zu hemmen (Romberg et al. 1986). Basierend auf der Beobachtung, dass geringe Osteonektin Konzentrationen das Wachstum von Hydroxylapatitkristallen in vitro verlangsamen, wird angenommen, dass Osteonektin als ein negativer Regulator fungiert indem es die Mineralisation viel mehr unterbindet als dass es sie fördert (Menanteau et al. 1982; Yamamoto et al. 2004). Eine Studie konnte zeigen, dass Zementoblasten, die das azelluläre Fremdfaserzement und das zelluläre Zement bilden, und Zementozyten mit einem anti-Osteonektin Antikörper reagierten (Reichert et al. 1992). Leider herrscht bezüglich des Osteonektins in Bezug auf Zement bislang ein Forschungs- bzw. Datendefizit (Bosshardt 2005).

\section{Osteocalcin}

Osteocalcin ist ein kleines Protein, bestehend aus 46 bis 50 Aminosäureresten, welches reichlich im Knochen, Dentin und Zement zu finden ist. Es scheint vor allem am Mineralisationsprozess beteiligt zu sein (Hauschka und Wians 1989). Bekannt ist Osteocalcin auch als Knochen-Gla (gamma-carboxyglutamic acid-containing) Protein (Hauschka et al. 1989). Im Knochen fördert die Gegenwart von zwei oder drei Gla-Resten die Affinität von Osteocalcin zu Kalziumionen (Hauschka und Carr 1982) und begünstigt die Aufnahme des Proteins in Hydroxylapatit (Poser und Price 
1979). Während der Wurzelentwicklung der Maus, konnte gezeigt werden, dass mRNA selektiv von an der Wurzeloberfläche liegenden Zementoblasten exprimiert wurde. Im Gegenteil dazu wird Osteocalcin-mRNA nicht im PDL exprimiert (D’Errico et al. 1997). Während die Immunfluoreszenz für Osteocalcin im azellulären Zement in einigen Studien mit Ratten negativ ausfiel (Bronckers et al. 1994; Kagayama et al. 1997), konnte eine andere Studie ein positives Ergebnis zeigen (Tenorio et al. 1993). Für alle drei Studien fiel das Ergebnis im zellulären Zement allerdings positiv aus, weshalb ein möglicher phänotypischer Unterschied zwischen Zementoblasten im azellulären und zellulären Zement vermutet wird (Bronckers et al. 1994). Eine weitere Studie hat die Genexpression von Osteocalcin im Zement der Ratte untersucht und konnte zeigen, dass sowohl auf mRNA-Level als auch im immunhistochemischen Nachweis sowohl Zementoblasten aus dem azellulären, als auch die aus dem zellulären Zement eine Expression zeigen. Die Frage nach einem unterschiedlichen Phänotyp bleibt deshalb weiterhin umstritten (Sasano et al. 2001).

Es existieren zahlreiche Studien, die mit Nagern durchgeführt wurden, sowohl zum Verteilungsmuster der Genexpression (MacNeil et al. 1996; Sommer et al. 1996; D'Errico et al. 1997) als auch immunhistochemische Nachweise von Kollagen Typ I, BSP, Osteocalcin und Osteopontin (Tenorio et al. 1993; Bronckers et al. 1994; Macneil et al. 1994; MacNeil et al. 1995a; Kagayama et al. 1997). Studien über humanes Zement, humane Zementoblasten und Zementozyten sind hingegen rar vertreten (Kitagawa et al. 2006; Salmon et al. 2013; Zhao et al. 2016b).

\section{Alkalische Phosphatase}

Alkalische Phosphatase (ALP) ist ein membrangebundenes Enzym, das Phosphatgruppen bei einem alkalischen $\mathrm{pH}-$ Wert hydrolisiert. Während in der Embryonalentwicklung ALP in den meisten Körperregionen exprimiert wird, beschränkt sich ihre Expression im Erwachsenenalter auf Knochen, Nieren, Leber und B-Lymphozyten. Die Tatsache, dass das Protein auch in nicht mineralisiertem Gewebe vorkommt, lässt darauf schließen, dass die ALP auch andere Funktionen, außer die mit Mineralisation assoziierten, erfüllt. Die ALP kann den Gewebeumbau und die Zellproliferation, Zelldifferenzierung und Zellreifung regulieren (Wuthier 1982; Hui und Tenenbaum 1998). Das Protein wird in hohen Mengen in PDL-Zellen exprimiert 
(Gibson und Fullmer 1967) und es wird angenommen, dass das Protein eine Rolle im Phosphat-Metabolismus und in der Zementbildung spielt (Beertsen et al. 1990). Mäuse, in deren Zellen das Protein nur mangelhaft vorhanden war, zeigten fehlerhafte Bildung von azellulärem Zement. Vergleichsweise dazu, konnten keine Missbildungen am Alveolarknochen, PDL und zellulärem Zement ausgemacht werden, was zu der Annahme führt, dass ALP unabdingbar ist für die Bildung von azellulärem Zement (Beertsen et al. 1999).

\section{Proteoglykane}

PG spielen eine wichtige Rolle in der Gewebsbildung und Mineralisation (Embery et al. 2001). An das Kernprotein der PG binden etliche GAG (Häkkinen et al. 1993). Die wichtigsten GAG, die im humanen Zement zu finden sind, sind Hyaloronsäure, Dermantansulfat und Chondroitinsulfat (Bartold et al. 1988). Unter den PG Arten, die mit Zement assoziiert werden, finden sich Lumican, Fibromodulin, Versikan, Dekorin, Biglykan und Osteoadherin (Ababneh et al. 1999; Cheng et al. 1999; Matias et al. 2003; Petersson et al. 2003). Versikan findet sich in Lakunen besetzenden Zementozyten. Dekorin wird eng in Verbindung mit Kollagenfasern des PDL und mit Biglykan im Zementoblast/Präzement-Bereich gebracht (Arzate et al. 2015). Osteoadherin, ein Keratinsulfat enthaltendes PG, wird in Verbindung mit der initialen Phase der Zementbildung gebracht, weil Zellen der HERS Osteoadherin während der Wurzelbildung exprimieren (Petersson et al. 2003).

\subsubsection{Schmelzassoziierte Proteine der Zement-Matrix}

Vor Jahren schon wurde die Hypothese aufgestellt, dass extrazelluläre Matrix-Proteine aus der HERS mit Schmelzproteinen verwandt sein könnten und dass sie die Bildung von azellulärem Zement initiieren könnten (Slavkin und Boyde 1974). Etliche Zementproteine (sowohl humane als auch aus der Maus) schienen immunologisch einigen Schmelzproteinen ähnlich zu sein (Slavkin et al. 1989). Später konnte gezeigt werden, dass Ameloblastin, ein ebenfalls mit Schmelz assoziiertes Protein, von Epithelzellen, die die erste unmineralisierte Dentinschicht der Wurzel bedecken, exprimiert wurde. Außerdem zeigten die Malassezschen Epithelreste ebenfalls ein starkes Signal (Fong et al. 1996; Fong und Hammarström 2000). Die Annahme, 
dass Schmelz-Matrix-Proteine, die von der HERS synthetisiert werden, in der Lage sein könnten, eine Zementoblasten-Differenzierung auszulösen, sorgte für etliche neue Therapieansätze in der Parodontologie (Arzate et al. 2015). Das Thema bleibt umstritten, denn während einige Forscher davon berichten, Amelogenin, welches von apikalen Zellen der HERS während früher Wurzelentwicklung sezerniert wurde, vorzufinden (Janones et al. 2005), können andere dies nicht bestätigen (Luo et al. 1991).

\subsubsection{Zement-spezifische Proteine der Zement-Matrix}

Über Jahre hinweg wurde daran geglaubt, dass unterschiedliche mineralisierte Gewebe für sie eigens spezifische Moleküle enthalten, die in keinem anderen Gewebe vorkommen (z.B. Amelogenin in Schmelz, Dentin-Sialophosphoprotein in Dentin, usw.) und die als Marker für diese Gewebe betrachtet werden können. Als die Nachweisverfahren genauer und sensibler wurden, wurde herausgefunden, dass viele dieser spezifischen Moleküle, wenn auch in deutlich geringerer Konzentration, auch in anderen Geweben exprimiert werden. Aufgrund der um einiges geringeren Konzentration in anderen Geweben, können diese Moleküle trotzdem als spezifische Marker betrachtet werden (Arzate et al. 2015).

Im Folgenden werden die wichtigsten als Zement-spezifisch betrachteten Proteine bzw. Marker vorgestellt.

\section{Cementum-derived growth factor}

Mittlerweile ist bekannt, dass mineralisierte Gewebe wie Knochen und Dentin exzellente Speicher von Wachstumsfaktoren darstellen. Diese können, wenn sie gebraucht werden, durch Demineralisation freigesetzt werden, um dann Gewebe zu reparieren oder zu regenerieren (Arzate et al. 2015). Auf ähnliche Art und Weise wurde gezeigt, dass manche Moleküle des Zementes die Fähigkeit besitzen, eine Reihe biologischer Aktivitäten wie z.B. Zellmigration, Adhäsion, mitogene Aktivität und Differenzierung zu fördern. All diese biologischen Aktivitäten sind unabdingbar für parodontale Regeneration (Grzesik und Narayanan 2002). Ein wichtiger Wachstumsfaktor, auf den 70 \% der mitogenetischen Aktivität zurückzuführen ist, wird als 
cementum-derived growth factor bezeichnet. Er stellt somit eine bedeutende Komponente des Zementes dar (Yonemura et al. 1992). Dieser Wachstumsfaktor kann die Migration und das Wachstum der Progenitorzellen in Richtung der Dentin-Matrix fördern und an ihrer Differenzierung in Zementoblasten beteiligt sein (Pitaru et al. 1994). Die Anwesenheit dieses und auch anderer Wachstumsfaktoren im Zement macht darauf aufmerksam, dass Zement das Potential hat, den Metabolismus und den Umsatz umgebender Gewebe zu regulieren und dass Zement als Speicher solcher wachstumsfördernder Moleküle dienen könnte. Auch deshalb liegt es nahe, dass solche Proteine dazu dienen die parodontale Regeneration zu fördern (Narayanan et al. 1995; Grzesik und Narayanan 2002).

\section{Cementum-derived attachment protein (CAP)}

Das CAP ist ein ca. 56 kDa großes, Kollagen ähnliches Protein, welches die Anlagerung von mesenchymalen Zellen an die EZM begünstigt (McAllister et al. 1990; Wu et al. 1996). CAP wurde sowohl in der gerade entstehenden als auch in der reifen Zement-Matrix und in Zementoblasten gefunden. Dabei wurde keine positive Reaktion im Alveolarknochen beobachtet (Arzate et al. 1992b; Wu et al. 1996; Arzate et al. 1998). CAP bindet an Hydroxylapatit und um einiges stärker an die Zement-, als an die Dentinoberfläche (Pitaru et al. 1993). Es konnte gezeigt werden, dass CAP die Adhäsion von Fibroblasten begünstigt, die von oralen Sulcusepithelzellen aber nicht (Olson et al. 1991). Das Protein bindet also selektiv an PDL-Zellen und unterstützt so die Anlagerung von PDL-Zellen an die Wurzeloberfläche (Pitaru et al. 1995). Es ist angenommen worden, dass CAP ein Markermolekül für die Zementogenese ist (Arzate et al. 1992b) und dass CAP in gewisser Weise mit der Entwicklung des Zementoblasten-Phänotyps verbunden ist (Pitaru et al. 1993). In vitro konnte sogar gezeigt werden, dass an CAP gebundene Zellen in der Lage sind, ein Zement ähnliches Gewebe zu produzieren (Liu et al. 1997).

\section{Cementum-protein 1 bzw. CP-23}

Das erste Mal isoliert wurde das Protein CP-23 aus humanem Zement und aus vom humanen Zementoblastom abstammendem Medium (Arzate et al. 1996; Arzate et al. 1998; Arzate et al. 2002). Das 26 kDa große Protein wird umfangreich durch 
posttranslationale Ereignisse modifiziert (Alvarez-Pérez et al. 2006). Es besteht aus 247 Aminosäuren und scheint ein alkalisches Protein ohne Signalpeptid zu sein (Arzate et al. 2015). Es reguliert das Kristallwachstum und die Struktur und Zusammensetzung von Apatitkristallen (Alvarez Pérez et al. 2003). Die Funktion des Proteins wurde über Transfektion in nicht mineralisierende Zellen, z.B. humane Gingivafibroblasten, weiter untersucht. Im Vergleich zu den normalen humanen Gingivafibroblasten zeigten die mit dem CP-23 transfektionierten Fibroblasten eine erhöhte Proliferation, eine Entstehung von mineralisierten Bereichen, eine erhöhte Aktivität der ALP und eine neu auftretende Expression von Osteocalcin, Osteopontin, BSP, RUNX2 und CAP. Diese Moleküle werden mit der Bildung von Knochen und Zement in Verbindung gebracht (Carmona-Rodríguez et al. 2007). Das Protein besitzt also die Fähigkeit, den Zellphänotyp von einem nicht-mineralisierenden in einen mineralisierenden Charakter zu ändern, indem es Proliferation und Genexpression reguliert. Aus dem Ganzen resultiert, dass sich diese Zellen differenzieren und eine dem Zement ähnliche EZM produzieren (Arzate et al. 2015). CP-23 wird in keinem anderen humanen Gewebe exprimiert, was die Annahme zulässt, dass das Protein ein Gewebe-spezifisches Protein ist, welches sich nur auf Zementoblasten und deren Progenitorzellen beschränkt. Außerdem könnte es eine Rolle als lokaler Regulator der Zelldifferenzierung und Mineralisation der EZM haben (Alvarez Pérez et al. 2003).

\subsection{Aufgabenstellung}

Die vorliegende Arbeit hat das Ziel, humane Zementoblasten zu gewinnen und deren Charakterisierung durchzuführen und zu beschreiben. Während zahlreiche Studien zu Zementoblasten aus Nagern oder anderen Wirbeltieren existieren, ist über humane Zementoblasten recht wenig bekannt. Um jedoch die Physiologie und Pathologie des Parodontiums im Ganzen zu verstehen, ist eine solche Untersuchung von großem Wert und wurde in der Literatur in solch einem Rahmen noch nicht beschrieben. Besonderes Augenmerk wird dabei auf die Proteine der EZM gelegt.

Zunächst wurden die humanen Zementoblasten aus extrahierten Zähnen gewonnen und kultiviert. Um mit den Zementoblasten ausreichend arbeiten zu können, 
wurden diese anschließend immortalisiert. Für die Charakterisierung wurden unterschiedlichste Methoden angewandt, um die Zelllinie z.B. sowohl auf mRNA-Ebene als auch via Western Blot auf Proteinebene zu untersuchen. Zusätzlich wurden die Proteine mittels FACS-Analyse und Immunfluoreszenz nachgewiesen.

Zum ersten Mal wurde mit Zementoblasten eine osteogene Differenzierung durchgeführt, die Aufschluss darüber geben sollte, ob und welche Gene einer unterschiedlich starken Genexpression vor bzw. nach der osteogenen Differenzierung, unterliegen. 


\section{Material und Methoden}

Im folgenden Kapitel werden die Materialien und Methoden beschrieben, die dieser Arbeit zugrunde liegen und für die Charakterisierung humaner Zementoblasten angewandt wurden.

\subsection{Zellkultur}

\subsubsection{Herkunft und Isolierung von Zementoblasten}

Die humanen Zementoblasten wurden am Universitätsklinikum Göttingen nach Zahnextraktionen gewonnen. Die Patienten befanden sich in unterschiedlichem Alter. Durchgeführt wurden die Extraktionen von Zahnärzten und Mund-Kiefer-Gesichtschirurgen der Universitätsklinik Göttingen. Das Durchführen dieser Studie wurde von der Ethikkommission der Medizinischen Fakultät der Universität Göttingen genehmigt (Antragsnummer 16/06/09). Um eine Verkeimung der Zellen zu vermeiden, wurden die extrahierten Zähne mit einer phosphatgepufferten Kochsalzlösung (PBS) gespült. Zur Abtötung von Bakterien und Pilzen wurden die Zähne mit Braunol behandelt. Um an das Wurzelzement zu gelangen, musste zunächst das PDL mit einem scharfen Skalpell entfernt werden. Anschließend wurde das Wurzelzement vorsichtig abgeschabt. Es wurde darauf geachtet, dass kein Dentin, welches sich unter dem Zement befindet, mit abgeschabt wird. Das abgeschabte Zement wurden in eine 6-Well-Platte mit DMEM+GlutaMax ${ }^{\mathrm{TM}}$, zugesetzt mit 10 \% FCS, gegeben. Die Zellen sind in der Lage auszuwandern und die Kunststoffoberfläche der 6-Well-Platte zu besiedeln. Die Kultur wurde für ca. eine Woche bei $37^{\circ} \mathrm{C}$ sowie $5 \% \mathrm{CO}_{2}$ und einer Luftfeuchtigkeit von $95 \%$ inkubiert. Die ausgewachsenen Zellen konnten weiter kultiviert werden und dienten als Ausgangsmaterial für die anschließende Immortalisierung und die danach folgenden experimentellen Untersuchungen.

\subsubsection{Kultivierung der Zementoblasten}

Die Zementoblasten wurden in Vorbereitung auf die Versuche von Christa Bode (AG 
Orale Biologie und Geweberegeneration der Poliklinik für Zahnärztliche Prothetik, ansässig im Uniklinikum Göttingen) immortalisiert und in Zellkulturflaschen (\#83.1813.002, Sarstedt, Nümbrecht, Dtl.) kultiviert.

Die Immortalisierung ermöglicht eine Kultivierung der Zellen in hohen Passagen ohne Zeichen von Seneszenz. Als Standardnährmedium für die Zellkultur diente Dulbecco's Modified Eagle's Medium (DMEM)+GlutaMax ${ }^{\mathrm{TM}}$ (Invitrogen, Darmstadt, Dtl.). Ergänzt wurde das Medium durch 10 \% Fetales Kälberserum FCS (\#10270106, Gibco, Paisley, UK) und $50 \mu \mathrm{g} / \mathrm{ml}$ Gentamycin (\#HN09.1, Roth, Karlsruhe, Dtl.). Das Medium wurde alle 3 bis 4 Tage gewechselt, damit den Zellen immer genügend Medium zur Vermehrung zu Verfügung stand. Es fand regelmäßig eine Kontrolle des Zellwachstums unter dem Mikroskop (Carl Zeiss, Göttingen) statt. Damit wurde sichergestellt, dass die Zellkulturflaschen nicht zu voll wachsen und die Zellen entarten. Die Zellkulturflaschen wurden im Inkubator (\#C200 von Labotect) bei $37^{\circ} \mathrm{C}$ sowie $5 \% \mathrm{CO}_{2}$ und einer Luftfeuchtigkeit von $95 \%$ gelagert.

Kultivierungsmedium DMED +/+:

500 ml DMEM (\#21885, Gibco, Paisley, UK)

50 ml Fetales Kälberserum FCS (\#10270-106, Gibco, Paisley, UK)

$500 \mu$ l Gentamycin (\#HN09.1, Roth, Karlsruhe, Dtl.)

\subsubsection{Passagieren der Zementoblasten}

Nach Erreichen einer Konfluenz von 80 \% mussten die Zementoblasten geerntet werden. Zunächst wurde das Medium verworfen und die Flaschen je zweimal mit PBS gewaschen, so konnten Proteinreste des Mediums entfernt werden. Anschließend wurde pro Flasche $2 \mathrm{ml}$ Trypsin (PAN Biotech, Aidenbach, Dtl.) pipettiert und für 2 bis 3 min im Brutschrank inkubiert. Das Lösen der Zellen vom Flaschenboden wurde durch leichtes Klopfen gegen die Flasche erreicht. Die mobilisierten Zellen wurden unter dem Mikroskop kontrolliert. Es wurde ein 50-ml-Falcon-Tube-Röhrchen (Sarstedt, Nümbrecht, Dtl.) mit 2 ml DMEM +/+ (DMEM mit Gentamycin und FCS) für die gelösten Zellen vorbereitet. Durch die Übertragung der gelösten Zellen aus den Flaschen in das Falcon-Tube-Röhrchen wurde die Trypsin-Aktivität beendet. Die Zellkulturflasche wurde anschließend zweimal mit Medium ausgespült, um 
die restlichen Zellen in das Falcon-Tube-Röhrchen zu übertragen. Danach wurden die Zellen 10 min bei 1200 Umdrehungen pro Minute zentrifugiert. Durch das Zentrifugieren konnten sich die Zellen vom Medium lösen. Der dadurch entstandene Überstand wurde abgenommen und das Zellpellet mit $1 \mathrm{ml}$ PBS resuspendiert. Anschließend wurde die Lebendzellzahl mit einem Zellometer (Cellometer Auto T4 Cell Counter, Firma Nexcelom Bioscience, Lawrence, USA) nach Gebrauchsanweisung des Herstellers errechnet. Neue Flaschen mit $1 \times 10^{4}$ Zellen pro Flasche wurden beimpft und mit $10 \mathrm{ml}$ Medium versetzt. Die restlichen Zellen wurden in Eppis (Eppendorf Safe-Lock Tube, Hamburg, Dtl.) umgefüllt und erneut 10 min bei 1200 Umdrehungen pro Minute zentrifugiert. Der entstandene Überstand wurde abpipettiert und die Zellpellets bei $-81^{\circ} \mathrm{C}$ bis zu ihrer weiteren Verwendung eingefroren. Nach diesem Durchlauf befanden sich die Zellen in der nächsthöheren Passage.

\subsection{Quantitative real-time Polymerase-Chain-Reaction}

\subsubsection{Allgemeines zur Methode}

Die quantitative real-time Polymerase-Chain-Reaction (qRT-PCR) ist eine Vervielfältigungsmethode für Nukleinsäuren und beruht auf dem Prinzip der normalen Polymerase-Kettenreaktion. Mit der qRT-PCR ist nicht nur eine Vervielfältigung von bestimmten Nukleinsäuresequenzen, sondern auch die Bestimmung der quantitativen Genexpression in Echtzeit möglich.

Bei der qRT-PCR werden cDNA Abschnitte mithilfe von synthetisierten Primern amplifiziert. Vor der Durchführung der Methode muss eine Isolierung von mRNA aus den Zellen stattfinden, um diese anschließend in cDNA umzuschreiben. Für die Durchführung der qRT-PCR wird eine hitzestabile Taq-Polymerase, die Temperaturen von $95{ }^{\circ} \mathrm{C}$ standhalten kann, und der Fluoreszenzfarbstoff SYBR-Green benötigt. Bei der qRT-PCR wird immer wieder der gleiche Zyklus an unterschiedlichen Phasen durchlaufen. Die erste Phase besteht aus der Denaturierung. Hierbei werden die Doppelstränge der DNA durch Erhitzen auf $95^{\circ} \mathrm{C}$ aufgetrennt. Die zweite Phase wird als das Primer-Annealing bezeichnet. Hier findet soweit eine Reduzierung der Temperatur statt, bis sich der spezifische Primer an die Einzelstränge der DNA anlagern kann. Die dritte und somit letzte Phase wird als Elongation bezeich- 
net. In dieser Phase werden die komplementären DNA Stränge von der Taq-Polymerase synthetisiert. Außerdem lagert sich in der dritten Phase der Fluoreszenzfarbstoff SYBR-Green an. In einem Thermocycler (Mastercycler, Eppendorf, Hamburg, Dtl.) wiederholen sich diese Phasen bis zu 45-mal. Im Idealfall verdoppelt sich die Zielsequenz nach jedem Zyklus, wodurch sich auch der Einbau des Fluoreszenzfarbstoffes SYBR-Green erhöht. Der Zyklus, an dem die Fluoreszenz zum ersten Mal über die Hintergrundfluoreszenz ansteigt bezeichnet man als CT-Wert (threshold cycle, Schwellenwert-Zyklus). Der Schwellenwert wird umso schneller erreicht, desto größere Mengen an DNA des gesuchten Zielgens vorhanden sind desto kleiner ist auch der CT-Wert und umgekehrt. Der CT-Wert erlaubt somit die Menge der gesuchten Zielsequenz, also des Zielgens zu bestimmen. Der CT-Wert und die Menge an DNA des Zielgens zeigen somit einen reziproken Zusammenhang. Die anschließend an die drei Phasen angezeigte Schmelzkurve stellt sicher, dass nur die gewünschte Zielsequenz amplifiziert wurde und keine unerwünschten Produkte wie z.B. Primer Dimere entstanden sind. Es ist wichtig, dass vor der Durchführung einer qRT-PCR eine Gradienten-PCR durchgeführt wird, um die AnnealingTemperaturen der eingesetzten Primer zu ermitteln.

\subsubsection{Isolierung von mRNA}

Die Isolierung von mRNA fand mithilfe des peqGOLD Total RNA Kit von der Firma PEQLAB Biotechnologie (Erlangen, Dtl.) statt. Entweder wurden die bei $-81^{\circ} \mathrm{C}$ eingefrorenen Zellpellets, oder Zellen direkt aus den Zellkulturflaschen verwendet. Zunächst wurden die Zellen durch Zugabe von $400 \mu$ RNA Lysis Buffer T lysiert, um anschließend das Lysat ohne Gewebereste auf ein DNA Removing Column, welches im Kit vorhanden ist und auf einem passenden Sammelröhrchen steckt, zu geben. Das Ganze wurde 1 min bei 10.000 g zentrifugiert, das DNA Removing Column verworfen und der Durchfluss mit $400 \mu \mathrm{l} 70$ \%-igem Ethanol versetzt. Die Lösung wurde in ein auf einem Sammelröhrchen sitzenden PerfectBind RNA Column gegeben und erneut 1 min bei $10.000 \mathrm{~g}$ zentrifugiert. Danach wurde der Durchfluss verworfen und es folgte ein Waschen mit $500 \mu$ RNA Wash Buffer I mit anschließendem zweimaligen Waschen mit $600 \mu$ I RNA Wash Buffer II. Zwischen jedem Waschschritt wurde die Probe $30 \mathrm{~s}$ bei $10.000 \mathrm{~g}$ abzentrifugiert und der Durchfluss 
jedes Mal verworfen. Anschließend wurde für $2 \mathrm{~min}$ bei $10.000 \mathrm{~g}$ trockenzentrifugiert. Danach wurden $30 \mu \mathrm{l}$ RNase freies destilliertes Wasser direkt auf die Matrix des PerfectBind RNA Column gegeben. Dadurch wurde die gewonnene RNA aus dem PerfectBind Column gespült und in einem Biopur 1,5-ml-Eppendorfcup aufgefangen. Anschließend wurde für $1 \mathrm{~min}$ bei $5000 \mathrm{~g}$ abzentrifugiert. Die Konzentration der gewonnenen mRNA konnte mithilfe des Nanodrop 1000 Spectrometers (PeqLab Biotechnologie GmBH, Erlangen, Dtl.) bestimmt werden.

\subsubsection{Umschreibung von mRNA in cDNA}

Bevor eine Genexpression mittels qRT-PCR bestimmt werden kann, ist es nötig mRNA in cDNA umzuschreiben. Die Umschreibung erfolgte mithilfe des QuantiTect Reverse Transkription Kits (Cat.No. 205313) von Qiagen (Venlo, Niederlande). Zunächst wurde die mRNA mit $2 \mu \mathrm{l}$ genomic DNA Wipeout Buffer versetzt und auf $14 \mu \mathrm{l}$ mit RNase freiem Wasser aufgefüllt. Anschließend wurde die Lösung bei $42{ }^{\circ} \mathrm{C}$ für 2 min inkubiert. Dann wurde die mRNA mit $4 \mu$ Transkriptionspuffer, $1 \mu$ reverser Transkriptase und $1 \mu \mathrm{l}$ Primermix gemischt und für $15 \mathrm{~min}$ bei $42{ }^{\circ} \mathrm{C}$ und anschlieBend für weitere 3 min bei $95^{\circ} \mathrm{C}$ inkubiert. Die mRNA wurde somit in cDNA umgeschrieben. Das Erhöhen der Temperatur von $42{ }^{\circ} \mathrm{C}$ auf $95^{\circ} \mathrm{C}$ sorgt für das Lösen der Stränge voneinander und stoppt somit den Vorgang. Die Lösung wird anschlieBend auf $200 \mu \mathrm{l}$ mit RNase freiem Wasser aufgefüllt. Man geht davon aus, dass die Umschreibung von mRNA zu cDNA in einem Verhältnis 1:1 stattfindet und somit eine cDNA-Konzentration von $200 \mathrm{ng} / 200 \mu \mathrm{lbzw} .1 \mathrm{ng} / \mu \mathrm{l}$ hat.

\subsubsection{Primer Design}

Die zielspezifischen Primer für CP-23 und Versikan wurden mit den Web-Programmen Primer3 und Primer-BLAST (http://ncbi.nlm.nih.gov) entworfen. Es wurden dabei folgende Parameter beachtet: Eine maximale Länge von 18-22 Basen, eine Guanin-Cytosin Konzentration von ca. $50 \%$ und eine Annealing-Temperatur von um die $60^{\circ} \mathrm{C}$. Die entworfene Primersequenz wurde anschließend mit der NCBI Blast Datenbank (Primer-Blast) überprüft, um eventuell entstehende alternative Produkte bei der PCR ausschließen zu können. Sofern keine alternativen PCR-Produkte vorlagen wurde die spezifische Sequenz bei der Firma Eurofins Genomics (Ebersberg, 
Dtl.) bestellt. Entsprechend der Angaben des Herstellers wurden die gelieferten Primer mit RNase freiem Wasser resuspendiert und anschließend bei $-21^{\circ} \mathrm{C}$ aufbewahrt.

Die Primer für Kollagen Typ I und III, SOX9, RUNX2, Dekorin, Osteopontin, BSP und VEGF waren bereits vorhanden und mussten nicht erst neu entworfen werden. Die Sequenzen der verwendeten Primer sind der Tabelle 6 zu entnehmen. Um die optimale Annealing-Temperatur bestimmen zu können wurde für CP-23 und Versikan eine Gradienten-PCR durchgeführt.

\subsection{6 qRT-PCR-Protokoll}

Es wurde das HotStar Taq DNA Polymerase Kit von der Firma Qiagen für die qRTPCR verwendet. Zuerst wurde ein Master-Mix-Ansatz in einem 1,5-ml-Eppendorfcup, wie in Tabelle 2 zu sehen ist, zusammenpipettiert. Um mögliche Pipettierfehler zu minimieren, wurde immer ein zusätzlicher Ansatz pipettiert. Das Pipettierschema ist in folgender Tabelle dargestellt.

Tab. 1: Primermix

\begin{tabular}{ll}
\hline Primermix & Menge in $\mu \mathrm{l}$ \\
\hline forward Primer & 20 \\
reverse Primer & 20 \\
RNase freies Wasser & 160 \\
\hline
\end{tabular}

Tab. 2: Mastermix für PCR

\begin{tabular}{ll}
\hline Mastermix pro Well & Menge in $\mu \mathrm{l}$ \\
\hline SYBR-Green & 5 \\
Primermix (forward/reverse) & 2 \\
RNase freies Wasser & 2 \\
\hline Totalvolumen & 9 \\
\hline
\end{tabular}

Um Verunreinigungen zu vermeiden und sauberes Arbeiten zu ermöglichen, wurde die PCR-96-Well-Platte mit einer Microseal B Adhesive Folie (Biozym Scientific $\mathrm{GmbH}$, Hessisch Oldendorf, Dtl.) zugeklebt und die Wells, die benötigt wurden freigeschnitten. Unter ständiger Kühlung wurden $9 \mu \mathrm{l}$ Mastermix und $1 \mu \mathrm{l}$ cDNA pro 
Well in eine PCR-96-Well-Platte (Biozym Scientific GmbH, Hessisch Olendorf, Dtl.) pipettiert und anschließend mit Opticat Flat Cape (Biozym Scientific GmbH, Hessisch Olendorf, Dtl.) verschlossen. Die befüllte Wellplatte musste anschließend für ca. 1 min bei 1200 Umdrehungen pro Minute abzentrifugiert werden, um dann in den Thermocycler gestellt zu werden. Die PCR wurde nach dem qRT-PCR-Protokoll (vgl. Tabelle 3) gestartet. Die Versuche wurden alle jeweils dreimal und mit dreifachen Ansätzen durchgeführt ( $n=9)$.

Tab. 3: qRT-PCR-Protokoll

\begin{tabular}{llll}
\hline Phase & Temperatur & Zeit & Zyklen \\
\hline Initiale Aktivierung & $95^{\circ} \mathrm{C}$ & $5 \mathrm{~min}$ & \\
Denaturierung & $95^{\circ} \mathrm{C}$ & $15 \mathrm{~s}$ & 45 \\
Annealing & Primer abhängig & $15 \mathrm{~s}$ & \\
Elongation & $72{ }^{\circ} \mathrm{C}$ & $20 \mathrm{~s}$ & \\
Finale Extension & $72^{\circ} \mathrm{C}$ & $10 \mathrm{~min}$ & \\
\hline
\end{tabular}

\subsubsection{Gradienten-PCR}

Um die Annealing-Temperatur für die Primer CP-23 und Versikan zu bestimmen, wurde eine Gradienten-PCR durchgeführt. Die Plätze 1-4 der Wellplatte wurden frei gelassen, 5-12 benutzt. Das bedeutet, dass in 8 Wells einer Wellplatte immer jeweils der gleiche Ansatz (Tabelle 2) pipettiert wurde, jedoch unterschiedliche AnnealingTemperaturen eingesetzt wurden. Folgende Temperaturen wurden gewählt:

$50,7{ }^{\circ} \mathrm{C}, 53,1^{\circ} \mathrm{C}, 55,5^{\circ} \mathrm{C}, 57,9^{\circ} \mathrm{C}, 60^{\circ} \mathrm{C}, 61,6{ }^{\circ} \mathrm{C}, 62,7{ }^{\circ} \mathrm{C}, 63^{\circ} \mathrm{C}$.

Tab. 4: Pipettierschema für Gradienten-PCR

\begin{tabular}{ll}
\hline Ansatz pro Well & Menge in $\mu \mathrm{l}$ \\
\hline SYBR-Green & 10 \\
Primermix (forward/reverse) & 4 \\
RNase freies Wasser & 4 \\
cDNA & 2 \\
\hline Totalvolumen & 20 \\
\hline
\end{tabular}


Auch die Gradienten-PCR wurde mit dem Thermocycler der Firma Eppendorf durchgeführt. Das Protokoll der Gradienten-PCR ist Tabelle 5 zu entnehmen. Nach Ablauf der PCR konnte mithilfe der Schmelzkurve die Annealing-Temperatur für die Primer bestimmt werden. Bei der Auswahl der Temperatur wurde auf die höchste Extinktion geachtet. Das bedeutet, dass die Schmelzkurve mit dem höchsten Ausschlag und der dazu passenden Temperatur gewählt wurde.

Tab. 5: Protokoll für Gradienten-PCR

\begin{tabular}{llll}
\hline Phase & Temperatur & Zeit & Zyklen \\
\hline Initiale Aktivierung & $95^{\circ} \mathrm{C}$ & $5 \mathrm{~min}$ & \\
Denaturierung & $95^{\circ} \mathrm{C}$ & $15 \mathrm{~s}$ & 45 \\
Annealing & variierend & $15 \mathrm{~s}$ & \\
Elongation & $72^{\circ} \mathrm{C}$ & $20 \mathrm{~s}$ & \\
Finale Extension & $72^{\circ} \mathrm{C}$ & $10 \mathrm{~min}$ & \\
\hline
\end{tabular}

\subsubsection{Verwendete Primer}

Tab. 6: Primer für PCR

\begin{tabular}{llll}
\hline Zielgen & Forward Primer $5^{\prime} \rightarrow 3^{\prime}$ & Reverse Primer $5^{\prime} \rightarrow 3^{\prime}$ & Annealing-Temp. \\
\hline CP-23 & tgagaacctcacctgcctct & accccttaggaagtggctgt & $63^{\circ} \mathrm{C}$ \\
Versikan & ggctccctctctggaaaagt & cgggagaaattcactggtgt & $60^{\circ} \mathrm{C}$ \\
SOX9 & caggctttgcgatttaagga & ccgttttaaggctcaaggtg & $60^{\circ} \mathrm{C}$ \\
RUNX2 & ttccagaccagcagcactc & cagcgtcaacaccatcatt & $63^{\circ} \mathrm{C}$ \\
BSP & gcagtagtgactcatccgaagaa & gcctcagagtcttcatcttcattc & $58^{\circ} \mathrm{C}$ \\
Dekorin & tcttccccctgacacaact & cgttccaacttcaccaaag & $56^{\circ} \mathrm{C}$ \\
Kollagen I & ttcccccagccacaaagagtc & cgtcatcgcacaacacct & $61^{\circ} \mathrm{C}$ \\
Kollagen III & ggattggaggtgaaaaag & gcggggttttacgagaa & $62^{\circ} \mathrm{C}$ \\
VEGF & tccaacttctgggctgttct & cccctctcctcttccttctc & $57{ }^{\circ} \mathrm{C}$ \\
Lamin A/C & ggtcactggaaagggaga & ttgctttggggaggagaga & $60^{\circ} \mathrm{C}$ \\
ALP & ccacgtcttcacatttggtg & agactgcgcctggtagttgt & $60^{\circ} \mathrm{C}$ \\
SOST & cacccctccatctcaaagaa & tgagtttgtgatggctgctc & $60{ }^{\circ} \mathrm{C}$ \\
RANKL & accagcatcaaaatcccaag & taaggaggggttggagacct & $60^{\circ} \mathrm{C}$ \\
\hline
\end{tabular}




\subsubsection{Statistik/Pfaffl}

Für die statistische Auswertung der qRT-PCR-Ergebnisse wurde die Pfaffl-Methode, die 2001 von Michael Walter Pfaffl beschrieben wurde, herangezogen. Die PfafflMethode dient der Datenanalyse und ist ein mathematisches Modell, welches eine statistische Auswertung von Expressionsergebnissen ermöglicht, indem es die relativen Expressionsverhältnisse berechnet. Für diese Methode ist ein Housekeeping-Gen nötig, welches im Gegensatz zu anderen Genen in allen Geweben exprimiert und zudem zeitlich unabhängig ist. Zeitlich unabhängig bedeutet, dass zu jedem Zeitpunkt eine konstante Expression stattfindet. Äußerst wichtig ist dabei, dass das Housekeeping-Gen, in diesem Fall Lamin A/C, keinen externen oder auch internen regulatorischen Einflüssen unterliegt. Die gewonnenen Ergebnisse der Normalisierung entsprechen den $\Delta \Delta \mathrm{CT}$-Werten. Die relative Expression des zu untersuchenden Zielgens wird in einem weiteren Schritt auf eine Kontrollprobe bezogen. Das bedeutet, dass sich die $\Delta \Delta \mathrm{CT}$-Werte aus dem Vergleich von relativer Expression des Zielgens zu der relativen Expression des Referenz- bzw. Kontrollgens ergeben. Als Kontrollprobe dienten immortalisierte Osteoblasten. Anschließend wurde die arithmetische Formel $2^{-\Delta \Delta C T}$ angewandt, um die Expressionsunterschiede zu ermitteln. Das Signifikanzniveau der $\Delta \Delta$ CT-Werte lag dabei bei $p<0,05$. Damit eine statistisch signifikante Aussage getroffen werden konnte, wurden die qRT-PCR-Untersuchungen jeweils dreimal durchgeführt.

\subsection{Osteogene Differenzierung}

Für die osteogene Differenzierung wurden zunächst $1,5 \times 10^{3}$ Zellen pro Flasche ausgesät. Zu dem klassischen Medium, dessen Zusammensetzung bereits beschrieben wurde, wurde am ersten Tag der Differenzierung zusätzlich $6 \mu$ Ascorbinsäure-2-Phosphat (Vitamin C) (PAN, Biotech GmbH, Dtl.) in einer Konzentration von 25,6 mg/10 ml und $6 \mu \mathrm{l}$ ß-Glycerolphosphat (Sigma Aldrich, G9422-10G, USA) in einer Konzentration von 2,16 g/10 ml hinzugefügt. Am zweiten Tag wurde das Medium gewechselt und $12 \mu \mathrm{l}$ Vitamin $\mathrm{C}$ und $12 \mu \mathrm{l}$ ß-Glycerolphosphat ins Medium gegeben. Die Zellkulturflaschen wurden im Inkubator bei $37^{\circ} \mathrm{C}$ sowie $5 \% \mathrm{CO}_{2}$ und einer Luftfeuchtigkeit von 95 \% für 18 Tage gelagert. Das Medium wurde alle 5 Tage gewechselt und sowohl Vitamin $\mathrm{C}$ als auch ß-Glycerolphosphat wurden immer frisch 
hinzugesetzt. Unter dem Mikroskop wurden die Zellen alle 3 bis 4 Tage kontrolliert und auf mögliche Entartungen untersucht. Nach Durchführung der Differenzierung wurden die Zellen, wie bereits beschrieben, geerntet und standen für weitere Nachweise zur Verfügung.

\subsection{Immunfluoreszenz}

\subsubsection{Allgemeines zur Methode}

Mithilfe der Immunfluoreszenz können gesuchte Proteine durch spezifische Antikörper, die an einen fluoreszierenden Farbstoff gekoppelt sind, in einem Fluoreszenzmikroskop sichtbar gemacht werden. Der Nachweis der gesuchten Proteine basiert auf einer Antigen-Antikörperreaktion. Von einer indirekten Immunfluoreszenz, wie sie hier bei den Versuchen stattgefunden hat, spricht man wenn der Antigen-Antikörperkomplex durch einen sekundären Antikörper sichtbar gemacht wird. Die sekundären Antikörper sind in diesem Fall an Fluorochrome (fluoreszierende Farbstoffe) gebunden und richten sich gegen den Antigen-Antikörperkomplex.

\subsubsection{Protokoll}

In dieser Arbeit wurde die Methode der Immunfluoreszenz verwendet, um folgende Proteine nachzuweisen: Kollagen Typ I, Kollagen Typ III, CP-23, SOX9, RUNX2, Dekorin, Osteopontin.

Um den Versuch durchführen zu können, war es nötig, die Zementoblasten auf sterilen Deckgläschen (DG,12 mm Durchmesser) aus Glas in einer 24-Well-Platte heranzuzüchten. Pro Well befand sich ein steriles DG, das mit jeweils 3000 Zellen resuspendiert in $1 \mathrm{ml}$ DMEM beladen wurde. Die 24-Well-Platte wurde anschließend für 6 Tage im Brutschrank bei $37^{\circ} \mathrm{C}$ kultiviert.

Wenn genug Zellen auf dem DG gewachsen waren, konnte das Nährmedium mithilfe einer Wasserstrahlpumpe vorsichtig abgesaugt und das DG zweimal mit PBS gewaschen werden. Anschließend wurde jedes DG auf eine mit Parafilm überzogene Box gelegt, und die Immunreaktion wurde nach dem unten beschriebenen Protokoll durchgeführt. 
Tab. 7: Materialien

\begin{tabular}{ll}
\hline $\begin{array}{l}\text { Paraformaldehyd } \\
\text { (Roth, Karlsruhe, Dtl.) }\end{array}$ & $\begin{array}{l}2 \% \text { Paraformaldehyd bei } 70{ }^{\circ} \mathrm{C} \text { in PBS } \\
\text { gelöst }\end{array}$ \\
Triton & $0,25 \%$ Triton X-100 in PBS gelöst \\
(Sigma-Aldrich, Steinheim, Dtl.) & \\
Bovine Serum Albumin (BSA) & $1 \%$ BSA in PBS gelöst \\
\hline
\end{tabular}

Fixierung:

bei Raumtemperatur 15 min in 2 \%-igem Paraformaldehyd in PBS einwirken lassen, $100 \mu$ pro DG

Waschen: zweimal mit PBS waschen, $100 \mu \mathrm{l}$ pro DG

Permeabilisieren: bei Raumtemperatur 10 min mit 0,25 \%-igem Triton in PBS

Waschen: bis Triton komplett entfernt ist mit PBS, $100 \mu$ pro DG

Blocken: bei Raumtemperatur 15 min mit $1 \%$-igem BSA in PBS, $100 \mu$ pro DG

Primärer Antikörper: $\quad$ Antikörper mit $1 \%$-igem BSA in PBS verdünnen, $50 \mu \mathrm{l}$ pro DG, $60 \mathrm{~min}$ bei $37^{\circ} \mathrm{C}$ die Zellen in einer feuchten Kammer inkubieren lassen

Waschen: zweimal mit PBS, $100 \mu$ pro DG

Sekundärer Antikörper: $\quad$ Antikörper mit $1 \%$-igem BSA in PBS+DAPI (KPL, Gaithersburg, USA) 1:1000 $50 \mu \mathrm{l}$ pro DG und anschließend $60 \mathrm{~min}$ bei $37^{\circ} \mathrm{C}$ in einer feuchten Kammer inkubieren lassen

Waschen: zweimal mit PBS, $100 \mu$ pro DG

Eindeckeln: ca. $10 \mu \mathrm{l}$ Mowiol auf einen Objektträger tropfen und das DG umgekehrt (Zellen nach unten) auf das Mowiol aufdrücken und überschüssiges Eindeckmedium absaugen

Anschließend konnten die Zellen auf dem Objektträger fotografiert (MOLCl, Molecular and Optical Live Cell Imaging) oder bei $-4{ }^{\circ} \mathrm{C}$ im Kühlschrank bis zu einer Woche aufbewahrt werden. 
2.4.3 Verwendete primäre und sekundäre Antikörper

Tab. 8: Immunzytochemie: Primäre Antikörper

\begin{tabular}{llll}
\hline Name & Herkunft & Verdünnung & Firma \\
\hline Kollagen I & Kaninchen, IgG polyklonal & $1: 50$ & Acris Antibodies \\
& & & R1038 \\
Kollagen III & Kaninchen, IgG polyklonal & $1: 50$ & $\begin{array}{l}\text { Acris Antibodies } \\
\text { AP06517PU-N }\end{array}$ \\
& & & Novus Biologicals \\
SOX9 & Maus, IgG monoklonal & $1: 50$ & H00006662-M02 \\
& & & Santa Cruz \\
RUNX2 & Kaninchen, IgG polyklonal & $1: 20$ & Sc-10758 \\
& & & Abnova, \\
CP-23 & Maus, IgG polyklonal & $1: 20$ & H00752014-B01P \\
& & & DSHB, Dekorin \\
Dekorin & Maus, IgG monoklonal & $1: 20$ & (6D6) \\
& & & DSHB, Osteopontin \\
Osteopontin & Maus, IgG monoklonal & $1: 20$ & $(\mathrm{MPIIIB10(1))}$ \\
& & &
\end{tabular}

Tab. 9: Immunzytochemie: Sekundäre Antikörper

\begin{tabular}{llll}
\hline Name & Herkunft & Verdünnung & Firma/Nummer \\
\hline $\begin{array}{l}\text { Donkey Anti-Rabbit IgG } \\
\left.\text { H\&L (Alexa Fluor }{ }^{\circledR} 555\right)\end{array}$ & polyklonal & $1: 1000$ & abcam, ab150074 \\
Goat Anti-Mouse IgG & Ziege, IgG & $1: 1000$ & abcam, ab150114 \\
H\&L (Alexa Fluor $\left.{ }^{\circledR} 555\right)$ & polyklonal & & \\
\hline
\end{tabular}

Die in Tabelle 9 aufgelisteten sekundären Antikörper wurden mit DAPI (KPL, Gaithersburg, USA) versetzt, was der Markierung (blau) des Nukleus diente. 


\subsection{Western Blot}

\subsubsection{Allgemeines zur Methode}

Beim Western Blot, auch bekannt unter dem Namen Immunoblot, werden Proteine auf eine absorbierende Membran (z.B. PVDF-Membran) übertragen und können gezielt in einem Proteingemisch nachgewiesen werden. Um die Proteine auf eine Membran übertragen zu können, müssen sie zunächst aufgetrennt werden. Dies kann z.B. durch die SDS-PAGE Methode erfolgen, bei der die Proteine nach ihrer Größe aufgetrennt werden. Über Gelelektrophorese werden die Proteine, während sie in einem Polyacrylamid-Gel durch ein elektrisches Feld wandern und sich aufgrund ihrer Ladung in Richtung Anode bewegen, in Proteinbanden aufgetrennt. Der eigentliche Western Blot besteht in der Übertragung der sich im Gel befindenden Proteine auf eine Polyvinylidenfluorid-(PVDF-) Membran. Das Gel wird dabei direkt auf die Membran gelegt und ein elektrisches Feld, welches senkrecht zur Membran steht, wird angelegt. Die Proteine wandern aufgrund ihrer Ladung erneut in Richtung Anode. Aufgrund hydrophober und polarer Wechselwirkungen bleiben die Proteine auf der Membran haften. Das Ganze geschieht in einem mit Transferpuffer gefüllten Tank. Die übertragenen bzw. geblotteten Proteine werden anschließend mit Antikörpern nachgewiesen. Der Primärantikörper ist für die Bindung an das gesuchte Protein verantwortlich. Der Sekundärantikörper wiederum, welcher an ein Enzym gekoppelt ist, bindet an den Primärantikörper. Das Enzym wandelt ein später hinzugegebenes Substrat um und sorgt für Fluoreszenz. Die Fluoreszenz erlaubt einen Nachweis entweder auf Fotopapier in der Dunkelkammer oder mit einem Blot Scanner. Bei diesen Versuchen wurde der C-DiGit ${ }^{\circledR}$ Blot Scanner der Firma LI-COR (Bad Homburg, Dtl.) verwendet. Mithilfe von vassarstats.net wurden die Ergebnisse auf ihre Signifikanz geprüft. Dabei wurde die Signifikanz wie folg festgelegt: * $=P<0,05$, ${ }^{* *}=\mathrm{P}<0,01,{ }^{* * *}=\mathrm{P}<0,001$.

\subsubsection{Proteinprobenvorbereitung}

Für das benötigte Proteingemisch wurden Zellpellets verwendet, die aus der Zellkultur gewonnen werden konnten. Die bei $-81{ }^{\circ} \mathrm{C}$ tiefgefrorenen Zellpellets wurden bei Raumtemperatur ca. 10 min aufgetaut. Anschließend wurden diese Zellpellets 
vor der Gelelektrophorese in 3-fach konzentriertem SDS-Probenpuffer resuspendiert. Der Probenpuffer beinhaltete $315 \mu \mathrm{l} 3$ x SDS-Probenpuffer und $35 \mu \mathrm{l}$ ß-Mercaptoethanol (Sigma-Aldrich, Steinheim, Dtl). Pro $1 \times 10^{6}$ Zellen wurde das Zellpellet mit $100 \mu$ Probenpuffer resuspendiert. Bei $95^{\circ} \mathrm{C}$ wurden die Zellpellets für $5 \mathrm{~min}$ in einem Heizblock (Thermocycler comfort, Eppendorf, Hamburg, Dtl.) erhitzt. Das Erhitzen führt zu einer Denaturierung der Proteine und somit zu einer besseren späteren Proteinauftrennung während der SDS-PAGE.

$\begin{array}{lll}3 \times \text { SDS-Probenpuffer: } & 3,6 \mathrm{~g} & 0,3 \mathrm{M} \text { Tris (Roth, Karlsruhe, Dtl.) } \\ 9 \mathrm{~g} & 9 \% \mathrm{SDS} \text { (Roth, Karlsruhe, Dtl.) } \\ 22,5 \mathrm{~g} & 22,5 \% \text { Glycerin (Roth, Karlsruhe, Dtl.) } \\ & \text { Spatelspitze Bromphenolblau vor SDS-Zu- } \\ & \text { gabe mit destilliertem Wasser auf } 100 \mathrm{ml} \\ & \text { auffüllen und } \mathrm{pH} 6,7 \text { einstellen }\end{array}$

\subsubsection{Polyacrylamid-Gel-Herstellung für SDS-PAGE}

Vor der eigentlichen Herstellung des Polyacrylamid-Gels mussten die Glasplatten, in denen das Gel später gegossen wird, mit 100 \%-igem Ethanol gereinigt werden. Anschließend wurden die Glasplatten zusammengebaut, indem eine Gummidichtung die beiden Glasplatten voneinander trennt und zwei Klammern das ganze Konstrukt zusammenhalten. Die Dichtigkeit der beiden Platten wurde entweder mit Ethanol oder destilliertem Wasser überprüft. Es wurde $6 \mathrm{~cm}$ von dem unteren Rand der Glasplatte aus eine Trennlinie eingezeichnet, die eine Grenze zwischen Trenngel und Sammelgel darstellen sollte. Entsprechend Tabelle 10 wurde das Trenngel zusammenpipettiert. Es musste dabei darauf geachtet werden, dass das Ammoniumperoxidsulfat (APS) (Roth, Karlsruhe, Dtl.) an letzter Stelle hinzugegeben wurde, da es nach einigen Sekunden zur Polymerisation des Gemisches führen würde. Das Trenngel wurde zwischen die mit Klammern befestigten Glasplatten gegossen und anschließend schnell mit 100 \%-igem Ethanol (AppliChem, Darmstadt, Dtl.) übergossen, um eine mögliche Entstehung von Luftblasen zu vermeiden. Nach etwa 15 min war das Trenngel auspolymerisiert, das Ethanol konnte wieder abgekippt werden und mit der Herstellung des Sammelgels konnte begonnen werden. In Tabelle 11 ist die Herstellung des Sammelgels beschrieben und auch hier ist darauf 
zu achten, dass APS aus oben genannten Gründen als Letztes hinzugegeben wird. Auch das Sammelgel wurde zwischen die beiden Glasplatten gegossen und sofort im Anschluss ein Kamm mit 10 Probentaschen in das Gel gesetzt. Nachdem das Gel vollständig auspolymerisiert war, konnten Kamm, Klammern und Dichtungsgummi wieder entfernt werden. Entweder wurde das Gel sofort für die SDS-PAGE eingesetzt oder es konnte ca. eine Woche in einer feuchten Kammer bei $4{ }^{\circ} \mathrm{C}$ im Kühlschrank aufbewahrt werden.

Tab. 10: Western Blot: Zusammensetzung Trenngel

\begin{tabular}{ll}
\hline Trenngel $10 \%$ & \\
\hline Trenngelpuffer & $1,4 \mathrm{ml}$ \\
$10 \%$ SDS & $55 \mu \mathrm{l}$ \\
TEMED & $5 \mu \mathrm{l}$ \\
Acrylamid & $1,85 \mathrm{ml}$ \\
$\mathrm{H}_{2} \mathrm{O}$ & $2 \mathrm{ml}$ \\
$10 \%$ APS & $0,25 \mathrm{ml}$ \\
\hline
\end{tabular}

Tab. 11: Western Blot: Zusammensetzung Sammelgel

\begin{tabular}{ll}
\hline Sammelgel $5 \%$ & \\
\hline Sammelgelpuffer & $1,25 \mathrm{ml}$ \\
$10 \%$ SDS & SDS $50 \mu \mathrm{l}$ \\
TEMED & $5 \mu \mathrm{l}$ \\
Acrylamid & $0,8 \mathrm{ml}$ \\
$\mathrm{H}_{2} \mathrm{O}$ & $2,7 \mathrm{ml}$ \\
$10 \%$ APS & $0,2 \mathrm{ml}$ \\
\hline
\end{tabular}

Sammelgelpuffer:

$15,1 \mathrm{~g}$ Tris $(0,25 \mathrm{M})$

$150 \mathrm{ml}$ destillierstes Wasser

mit $\mathrm{HCl}$ auf $\mathrm{pH}$ 6,8 einstellen

Trenngelpuffer:

45,4 g Tris (1,5 M)

$250 \mathrm{ml}$ destilliertes Wasser

mit $\mathrm{HCl}$ auf $\mathrm{pH} 8,9$ einstellen 


\title{
2.5.4 Natriumdodecylsulfat-Polyacrylamidgelelektrophorese/SDS- PAGE
}

Die eigentliche Gelelektrophorese wurde mit dem Nachbau einer Biometra Elektrophoresekammer durchgeführt. Zunächst wurden die Kammern der Vorrichtung mit 1 x Laufpuffer aufgefüllt. Anschließend wurde das Gel, welches sich zwischen den beiden Glasplatten befindet, eingesetzt und mit zwei Klammern fixiert. Die vorbereiteten Proben wurden noch möglichst heiß in die Taschen aufgetragen. Eine Proteinleiter (Fermentas, \#SM0671) wurde ebenfalls in eine der Taschen aufgetragen, um später das Ablesen des genauen molekularen Gewichtes zu ermöglichen. Pro Tasche wurde $25 \mu$ l Volumen des Proteingemisches und $4 \mu$ l Volumen der Proteinleiter aufgetragen. Um die Gelelektrophorese zu beginnen, wurde zunächst bis zum Erreichen der Grenze zwischen Trenngel und Sammelgel eine Stromstärke von 15 mA angelegt. Ab Erreichen der Grenze wurden die Proteine mit einer Stromstärke von $25 \mathrm{~mA}$ aufgetrennt. Sobald die komplette Proteinleiter sichtbar war und kurz vor Ende des Trenngels, wurde die Gelelektrophorese gestoppt.

\author{
5 x SDS Laufpuffer: $\quad 30,3 \mathrm{~g}$ Tris $(0,25 \mathrm{M})$ \\ 142,6 g Glycin (1,9 M) \\ $0,5 \%$ SDS (50 ml $10 \%$ SDS) \\ mit destilliertem Wasser auf $1000 \mathrm{ml}$ auffüllen
}

\subsubsection{Western Blot (Immunoblot)}

Zu Beginn wurde eine Blotkassette (PaqLab Biotechnologie GmbH, Erlangen, Dtl.), bestehend aus 2 Schwämmen, 6 Filterpapieren und einer PVDF-Membran, die zuvor für $15 \mathrm{~s}$ in $100 \%$-igem Methanol aktiviert wurde, zusammengebaut. In einer mit kaltem Transferpuffer gefüllten Schale erfolgte der Zusammenbau der Blotkassette. Dabei wurde auf die Anodenseite zuerst ein Schwamm, dann drei Filterpapiere und schließlich die aktivierte PVDF-Membran gelegt. Auf die Membran selber wurde direkt das Trenngel platziert. Das Trenngel wurde zuerst von drei Filterpapieren und dann einem Schwamm bedeckt. Die Kassette wurde mit Gummibändern verschlossen und in einen mit Transferpuffer gefüllten Tank eingesetzt. Vor dem Zusammenbau mussten die 6 Filterpapiere und 2 Schwämme mindestens für 15 min in kaltem 
Transferpuffer eingelegt werden. Eine integrierte Wasserkühlung und ein Rührfisch sorgten für eine konstant kalte Temperatur im Tank. Es wurde für 90 min eine Stromstärke von 350 mA angelegt und die aufgetrennten Proteine somit vom Trenngel auf die PVDF-Membran übertragen.

Transferpuffer:

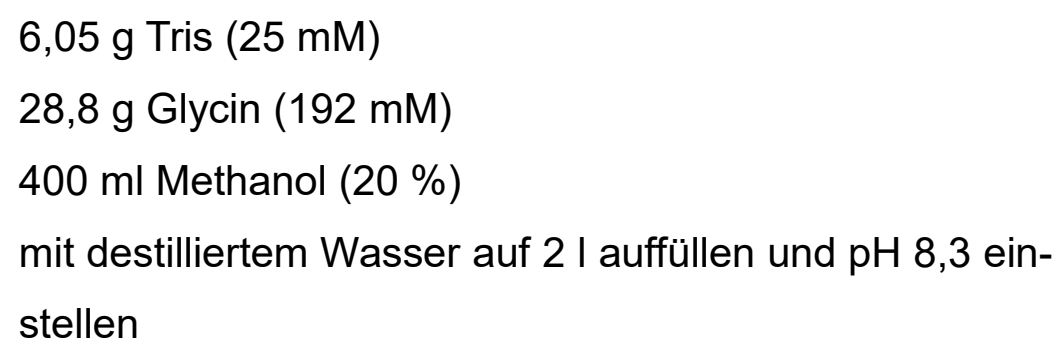

\subsubsection{Proteindetektion}

Nach dem Transfer wurde die Membran ca. 5 bis 10 min in einer Färbelösung, dem Coomassie-Brilliant-Blau (Roth, Karlsruhe, Dtl.) geschwenkt. Anschließend wurde die Membran mit einer Entfärberlösung, bestehend aus Methanol und Essigsäure so lange gewaschen bis der Hintergrund entfärbt war. Meist waren bereits 2 min ausreichend. Zu Dokumentationszwecken wurde die Membran nach dem Entfärben und einmaligem Waschen mit TBS-T eingescannt. Vor der spezifischen Proteindetektion bzw. der Immunreaktion wurde die Membran 5 × 5 min mit TBS-T gewaschen, um mögliche Reste an Methanol und Essigsäure zu entfernen.

Färbelösung:

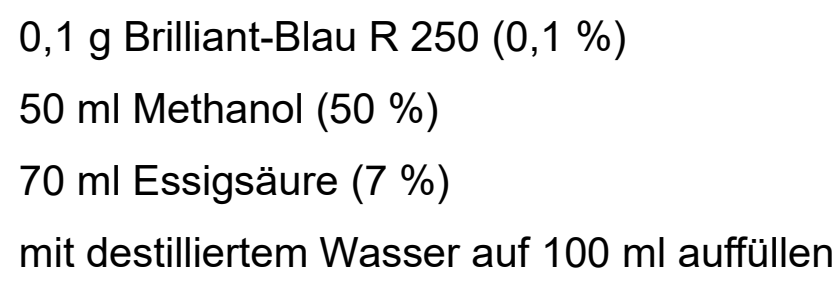

\subsubsection{Immunmarkierung}

Damit unspezifische Bindungen der primären Antikörper vermieden werden konnten, musste die Membran bevor sie mit den Primärantikörpern inkubiert wurde, für 
eine Stunde bei Raumtemperatur, je nach verwendetem Antikörper entweder mit $5 \%$ Milchlösung oder mit $5 \%$ BSA-Lösung (Bovine Serum Albumin) geblockt werden. Die Blocklösungen wurden frisch angesetzt und bestanden entweder aus $5 \%$ Milchpulver (Roth, Karlsruhe, Dtl.), oder 5 \% BSA (Sigma Aldrich, Steinheim, Dtl.) gelöst in TBS-T. Nach Angaben des Herstellers und in der richtigen Konzentration wurden die primären Antikörper in den Blocklösungen auf die Membran gegeben und über Nacht auf einer Wippe im Kühlraum bei $4{ }^{\circ} \mathrm{C}$ inkubiert. Um die primären Antikörper von der Membran zu entfernen, wurde diese 5 x 5 min mit TBS-T auf einer Wippe gewaschen. Nach dem Waschen konnte der Sekundärantikörper, ebenfalls in Blocklösung, auf die Membran gegeben werden. Der HRP (horseraddish peroxidase) gekoppelte Sekundärantikörper wurde nach der Herkunft des Primärantikörpers, also aus welchem Wirt dieser gewonnen wurde, ausgewählt. Es folge eine Inkubation des Sekundärantikörpers für eine Stunde bei Raumtemperatur. Anschließend wurde wieder $5 \times 5$ min mit TBS-T gewaschen, um mögliche Reste des Primärantikörpers zu entfernen. In Tabelle 12 und 13 sind die verwendeten Primär- und Sekundärantikörper mit ihrer Herkunft gelistet. Der Nachweis der Immunreaktion erfolgte entweder mit dem Western Bright TM ECL Reagenz (Advansta, Menlo Park, USA) oder mit dem etwas stärker lumineszierenden Western Brigth TM Sirius (Advansta, Menlo Park, USA). Lösung A und B aus den Kits wurden in einem Verhältnis von 1:1 zusammengemischt und inkubierten 5 min in Dunkelheit auf der Membran. Anschließend wurde die Membran mit dem C-DiGit ${ }^{\circledR}$ Blot Scanner (LICOR, Homburg, Dtl.) gescannt und mithilfe des Image Studio Digits C-Digit Programmes sichtbar gemacht. Mithilfe der Proteinleiter und der Höhe der gesuchten Proteinbande war es möglich, das molekulare Gewicht des gesuchten Proteins zu bestimmen und auszuwerten.

Blocklösung 1 (5 \% Milch): $\quad 2,5 \mathrm{~g}$ Milchpulver $100 \mathrm{ml} 1 \times$ TBS-T

Blocklösung 2 (5 \% BSA): $\quad 2,5 \mathrm{~g} \mathrm{BSA}$

$100 \mathrm{ml} 1 \times$ TBS-T 


\subsubsection{Verwendete Antikörper}

Tab. 12: Western Blot: primäre Antikörper

\begin{tabular}{llll}
\hline Name & Herkunft & Verdünnung & Firma \\
\hline Kollagen I & Kaninchen, IgG polyklonal & $1: 50$ & Acris Antobodies \\
& & & R1038 \\
SOX9 & Maus, IgG monoklonal & $1: 50$ & Novus Biologicals \\
& & & H00006662-M02 \\
RUNX2 & Kaninchen, IgG polyklonal & $1: 20$ & Santa Cruz \\
& & & sc-10758 \\
\hline
\end{tabular}

Tab. 13: Western Blot: sekundäre Antikörper

\begin{tabular}{llll}
\hline Name & Herkunft & Verdünnung & Firma/Nummer \\
\hline $\begin{array}{l}\text { Anti-Mouse IgG } \\
\text { (Fab specific) }\end{array}$ & $\begin{array}{l}\text { Ziege, IgG } \\
\text { polyklonal }\end{array}$ & $1: 40000$ & Sigma Aldrich \\
& & & A9917 \\
Anti-Rabbit lgG & Ziege, IgG & $1: 100000$ & Sigma Aldrich \\
(whole molecule) & polyklonal & & A0545 \\
\hline
\end{tabular}

\subsection{Durchflusszytometrie (FACS)}

Die Durchflusszytometrie welche auch unter dem Namen FACS (fluorescence activated cell sorting) bekannt ist, wird zur Untersuchung von Zellsuspensionen angewandt. Mithilfe der FACS-Analyse ist es möglich Zellen in verschiedene Populationen zu trennen und zu sortieren. Eingesetzt wird diese Methode z.B. für einen Nachweis von spezifischen Zelloberflächenantigenen und intrazellulären Antigenen. Ein solcher Nachweis erfolgt mithilfe von Antikörpern. Für die Charakterisierung der Zementoblasten wurde ein Nachweis von intrazellulären und intranukleären Antigenen durchgeführt.

Nachdem die Zellen wie bereits beschrieben geerntet wurden, wurden für die Analyse zunächst je $1 \times 10^{4}$ Zellen pro FACS-Röhrchen (Falcon 352058) mit Zugabe von $1 \mathrm{ml}$ PBS zentrifugiert. Anschließen wurde eine Lösung aus PBS und $5 \%$ FCS 
angesetzt, die für die weiteren Waschschritte eingesetzt wurde. Für die Analyse der intrazellulär liegenden Antigene wurde zusätzlich zur Antikörperinkubation das Fix \& Perm ${ }^{\circledR}$-Kit (Invitrogen Corporation, USA) verwendet. Die Zellpellets wurden dafür zuerst mit $100 \mu \mathrm{l}$ der Fixierlösung A (Reagenz A) für 15 min im Dunkeln und bei Raumtemperatur inkubiert. Nach Inkubation wurde für 5 min und mit $3 \mathrm{ml}$ PBS+FCS bei $350 \mathrm{~g}$ gewaschen. Nach dem Waschen wurde der Überstand verworfen. Anschließend wurden die Pellets mit $100 \mu$ l Permeabilitätslösung B (Reagenz B) mit $2 \mu \mathrm{l}$ primärem Antikörper für eine Stunde im Dunkeln und bei Raumtemperatur inkubiert. Danach folgte ein weiterer Waschschritt mit PBS+FCS. Nach Abkippen des Überstandes erfolgte die Inkubation mit dem sekundären Antikörper für weitere 30 min. Die Pellets wurden erneut mit PBS+FCS gewaschen und der Überstand entfernt. Zum Schluss wurden die Pellets mit ca. $300 \mu \mathrm{l}$ resuspendiert und die FACS-Analyse konnte durchgeführt werden.

\subsubsection{Eingesetzte Antikörper}

Tab. 14: FACS: primäre Antikörper

\begin{tabular}{llll}
\hline Name & Herkunft & Menge in $\mu \mathrm{l}$ & Firma \\
\hline Kollagen I & Kaninchen, IgG polyklonal & 2 & Acris Antibodies \\
& & & R1038 \\
SOX9 & Maus, IgG monoklonal & 2 & Abnova \\
& & & H00006662-M01 \\
RUNX2 & Kaninchen, IgG polyklonal & 2 & Santa Cruz \\
& & & sc-10758 \\
Osteonektin & Maus, IgG monoklonal & 2 & DSHB, Osteonektin \\
& & & AON-1 \\
\hline
\end{tabular}


Tab. 15: FACS: sekundäre Antikörper

\begin{tabular}{|c|c|c|c|}
\hline Name & Herkunft & Menge in $\mu \mathrm{l}$ & Firma/Nummer \\
\hline Donkey Anti-Rabbit IgG & Esel, IgG & 2 & abcam, ab150074 \\
\hline H\&L (Alexa Fluor $\left.{ }^{\circledR} 555\right)$ & polyklonal & & \\
\hline Goat Anti-Mouse $\lg G$ & Ziege, IgG & 2 & abcam, ab150114 \\
\hline H\&L (Alexa Fluor ${ }^{\circledR} 555$ ) & polyklonal & & \\
\hline
\end{tabular}




\section{Ergebnisse}

\subsection{Primäre humane Zementoblasten}

Abbildung 1 zeigt lichtmikroskopische Aufnahmen primärer humaner Zementoblasten sowohl in einer Übersichtaufnahme als auch in einer Detailaufnahme.
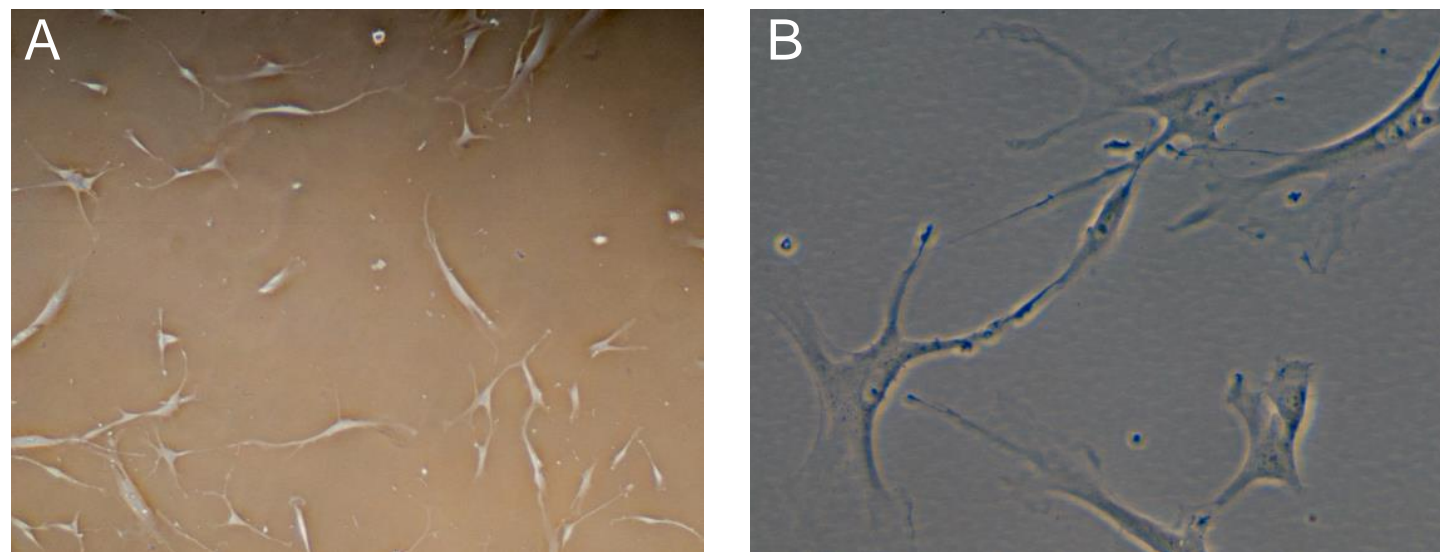

\section{Abb. 1: Lichtmikroskopische Darstellung von primären Zementoblasten}

Beide Aufnahmen zeigen noch nicht immortalisierte Zementoblasten nach einer Kultivierungsphase von 5 bis 6 Tagen. Die Zellen befinden sich auf diesen Aufnahmen in Passage 3 (P3).

A: Übersichtaufnahme mit 5-facher Vergrößerung. B: Detailaufnahme mit 20-facher VergröBerung.

\subsection{Nachweis über die Immortalisierung der Zementoblasten}

Um die durchgeführte Immortalisierung der zementoblastären Zellen nachweisen zu können, wurde zuerst eine PCR mit dem Primer hTERT durchgeführt. Aufgrund seiner Größe, die bei 400 Basenpaaren liegt, konnte das Produkt der qPCR daraufhin in einem 1,5 \%igen TAE-Agarosegel nachgewiesen werden. Die DNA-Leiter, die rechts und links zu sehen ist, dient dabei als Referenzskala. Um das Ergebnis der PCR kontrollieren zu können, wurden links bereits erfolgreich immortalisierte CPCs aufgetragen. 


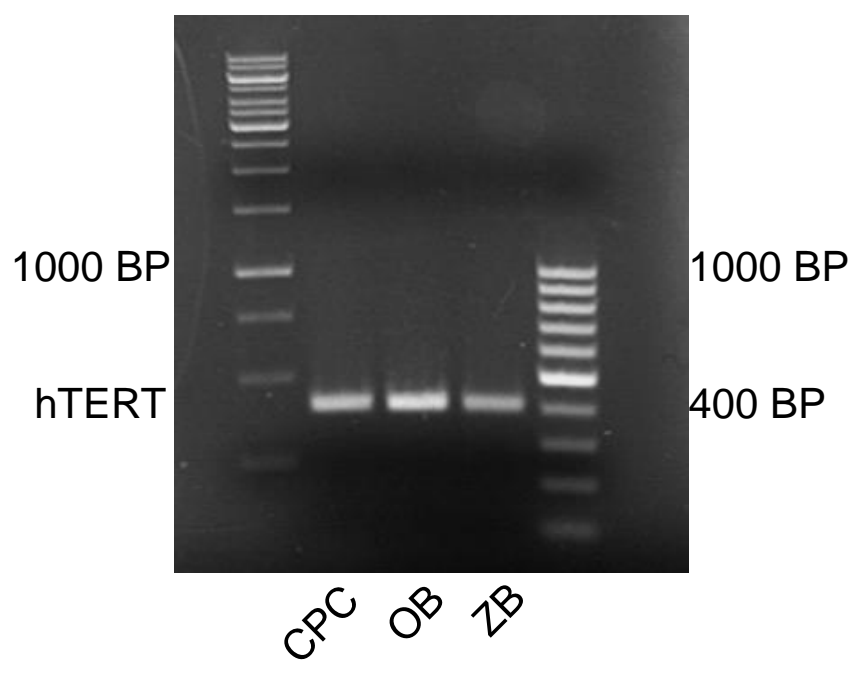

\section{Abb. 2: Nachweis über Immortalisierung der Zementoblasten im Agarosegel}

Ganz links sind bereits immortalisierte CPCs aufgetragen. Daneben sind Osteoblasten (OB) und Zementoblasten (ZB) dargestellt, die auf gleicher Höhe wie die CPCs eine Bande besitzen. Das bedeutet, dass sowohl die Osteoblasten als auch die Zementoblasten erfolgreich immortalisiert werden konnten. Die gleiche Abbildung ist in der Arbeit von Diana Dillschneider mit dem Titel "Gewinnung und Charakterisierung von osteoblastären Zellen aus dem humanen Alveolarkamm" abgebildet.

\subsection{Lichtmikroskopische Aufnahmen}

Im Folgenden werden weitere lichtikroskopischen Aufnahmen vorgestellt. Abbildung 3 zeigt Aufnahmen von immortalisierten humanen Zementoblasten. Die immortalisierten Zellen wurden im Verlauf dieser Arbeit einer osteogenen Differenzierung unterzogen. Abbildung 4 zeigt osteogen differenzierte Zementoblasten. Die Bilder wurden jeweils kurz vor der Ernte der Zellen aufgenommen, möglichs bevor eine Konfluenz von $70 \%$ überschritten wurde. 
3.3.1 Lichtmikroskopische Aufnahmen undifferenzierter Zementoblasten
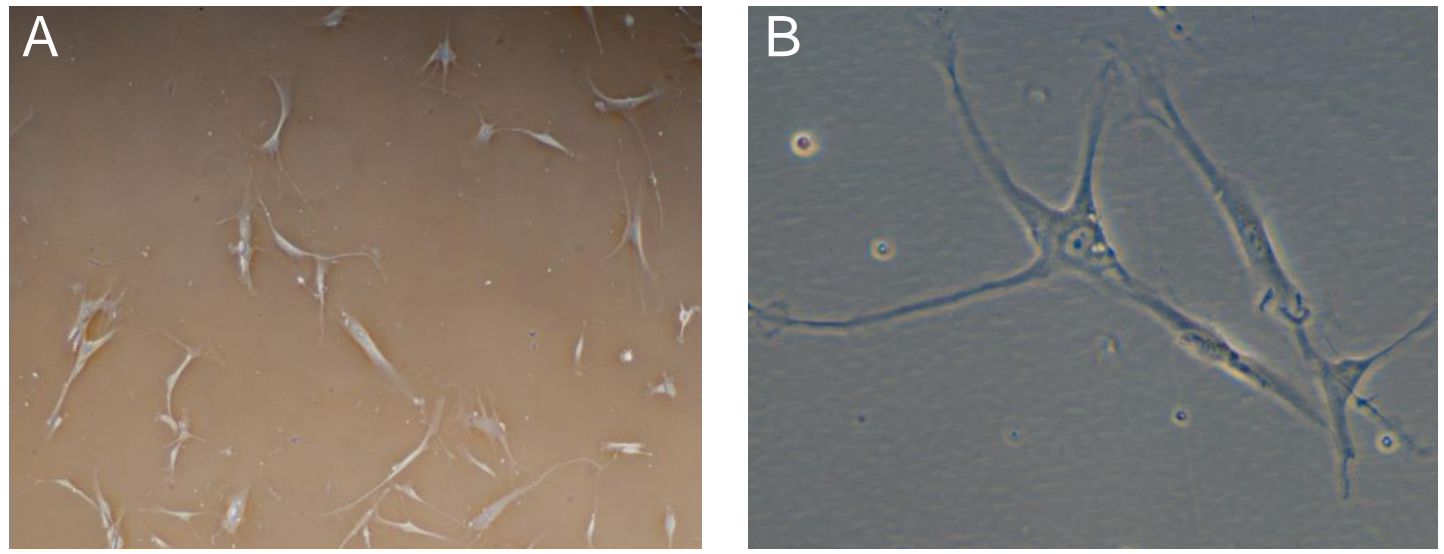

\section{Abb. 3: Übersicht- und Detailaufnahme von Zementoblasten}

Beide Aufnahmen zeigen bereits immortalisierte Zementoblasten nach einer Kultivierungsphase von 5 bis 6 Tagen. Die Zellen befinden sich auf diesen Aufnahmen in Passage 12 (P12).

A: Übersichtaufnahme mit 5-facher Vergrößerung. B: Detailaufnahme mit 20-facher Vergrößerung. 
3.3.2 Lichtmikroskopische Aufnahmen osteogen differenzierter Zementoblasten
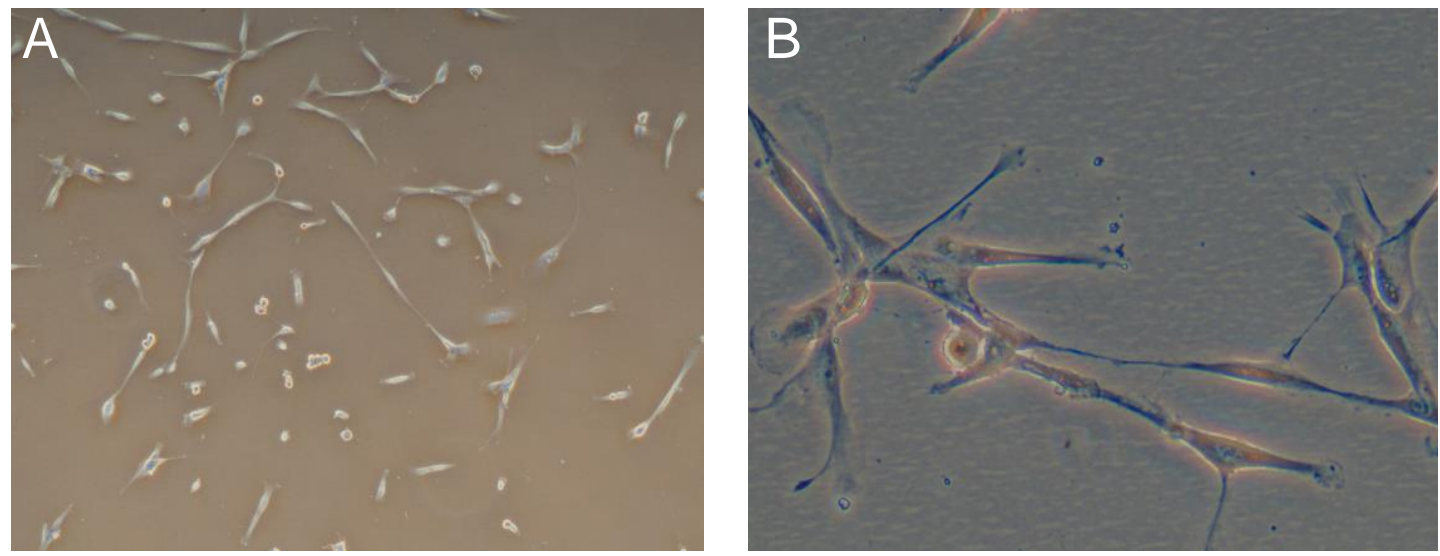

\section{Abb. 4: Übersicht- und Detailaufnahme differenzierter Zementoblasten}

Beide Aufnahmen zeigen bereits immortalisierte Zementoblasten die osteogen differenziert wurden. Die Aufnahmen entstanden nach einer Differenzierungsphase von 18 Tagen. Die Zellen befinden sich auf diesen Aufnahmen in Passage 14 (P14).

A: Übersichtaufnahme mit 5-facher Vergrößerung. B: Detailaufnahme mit 20-facher Vergrößerung. 


\subsection{Genexpression auf mRNA-Level}

Abbildung 5 und 6 zeigen das relative mRNA-Level unterschiedlicher, sowohl kollagener als auch nicht-kollagener Proteine der EZM. In Abbildung 5 ist zu sehen, dass Kollagen Typ I am stärksten exprimiert wird. SOX9, ein eigentlich für die chondrogene Zelllinie typischer Transkriptionsfaktor, konnte mittels qRT-PCR ebenfalls in Zementoblasten nachgewiesen werden, genau wie das Signalmolekül VEGF, welches für die Gefäßbildung notwendig ist. Das relative mRNA-Level der PG Versikan und Dekorin, aber auch das Expressionslevel der typischen nicht-kollagenen Proteine der EZM wie BSP und Osteocalcin werden in Abbildung 6 dargestellt. CP-23, das in der Literatur bisher als spezifischer Marker für Zement galt, konnte auch in der Kontrolle, welche in diesem Fall von Osteoblasten aus dem Alveolarkamm gebildet wurde, nachgewiesen werden. Desweiteren wurden die Zementoblasten für 18 Tage osteogen differenziert und auf einige nicht-kollagene Proteine nochmals neu mittels qRT-PCR untersucht. Signifkant und auswertbar waren die Untersuchungen für Osteocalcin und CP-23. In Abbildung 7 ist zu sehen, dass das Expressionslevel von Osteocalcin in den osteogen differenzierten Zellen fast unverändert bleibt. Das CP-23 Expressionslevel hingegen fällt in den differenzierten Zellen im Vergleich zu den nicht differenzierten Zellen stark ab. Als Kontrolle wurden in diesem Fall nicht osteogen differenzierte Zementoblasten herangezogen. 


\subsubsection{Relatives mRNA-Level von Zementoblasten}

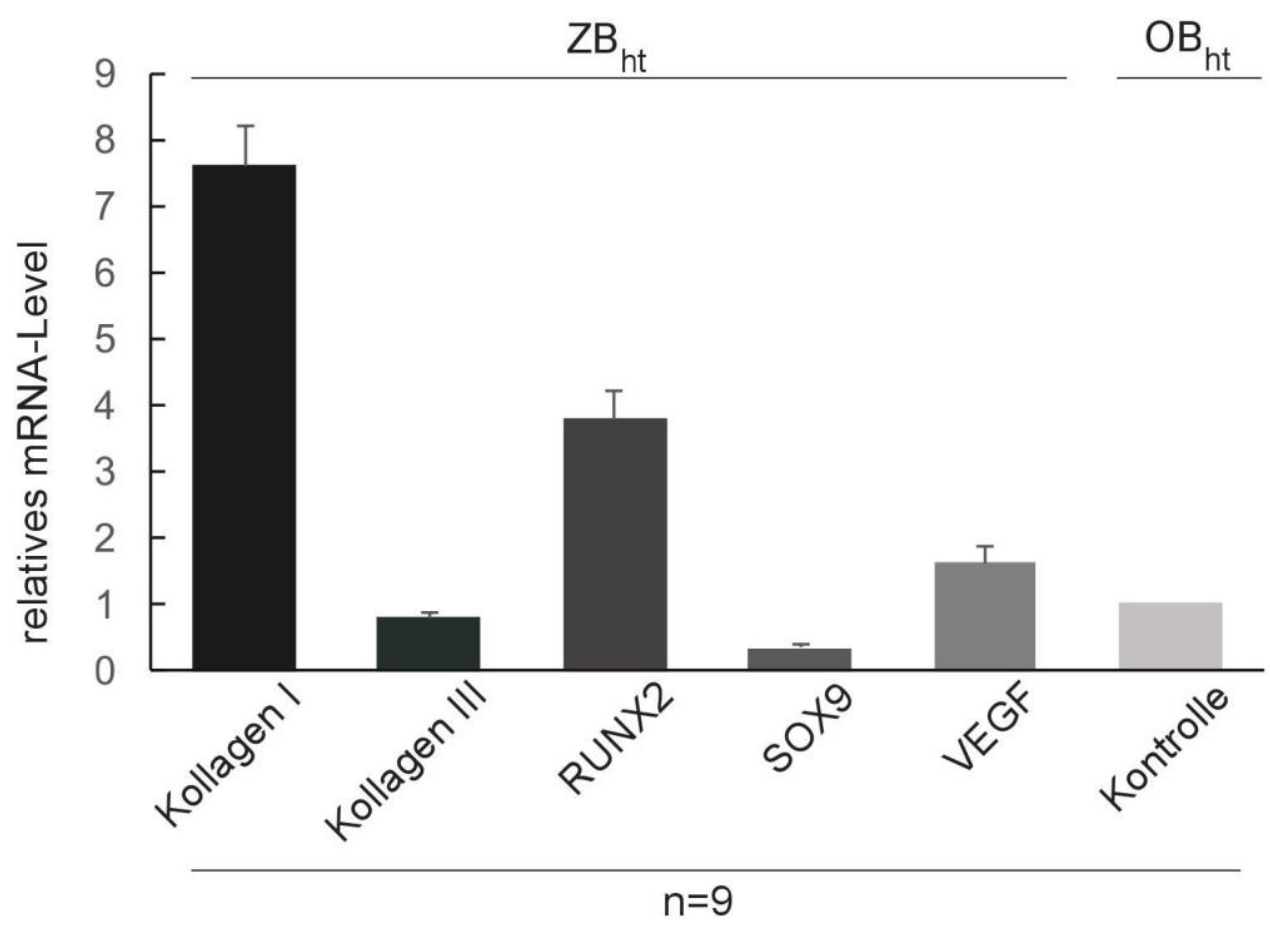

\section{Abb. 5: Relatives mRNA-Level undifferenzierter Zementoblasten von Protei- nen der extrazellulären Matrix}

In Abbildung 5 werden die unterschiedlichen Expressionslevel sowohl kollagener als auch nicht-kollagener Proteine der EZM dargestellt. Neben der Darstellung von Kollagen Typ I und III wird das relative mRNA-Level der beiden Transkriptionsfaktoren RUNX2 und SOX9 dargestellt. SOX9 ist eigentlich ein für Knorpelgewebe typischer Transkriptionsfaktor. VEGF, ein Signalmolekül welches für die Ausbildung und Neubildung von Blutgefäßen wichtig ist, konnte ebenfalls in Zementoblasten ( $\left.Z B_{h t}\right)$ nachgewiesen werden. Als Kontrolle wurden Osteoblasten $\left(\mathrm{OB}_{\mathrm{ht}}\right)$ eingesetzt. Der Nachweis der in dem Graphen zu sehenden Proteine erfolgte auf mRNA-Level. Die Ergebnisse belaufen sich dabei auf die Mittelwerte im Vergleich zur Kontrolle. Die Fehlerbalken beschreiben die Standardabweichung. Die Nummer der Replikate ist $\mathrm{n}$. 


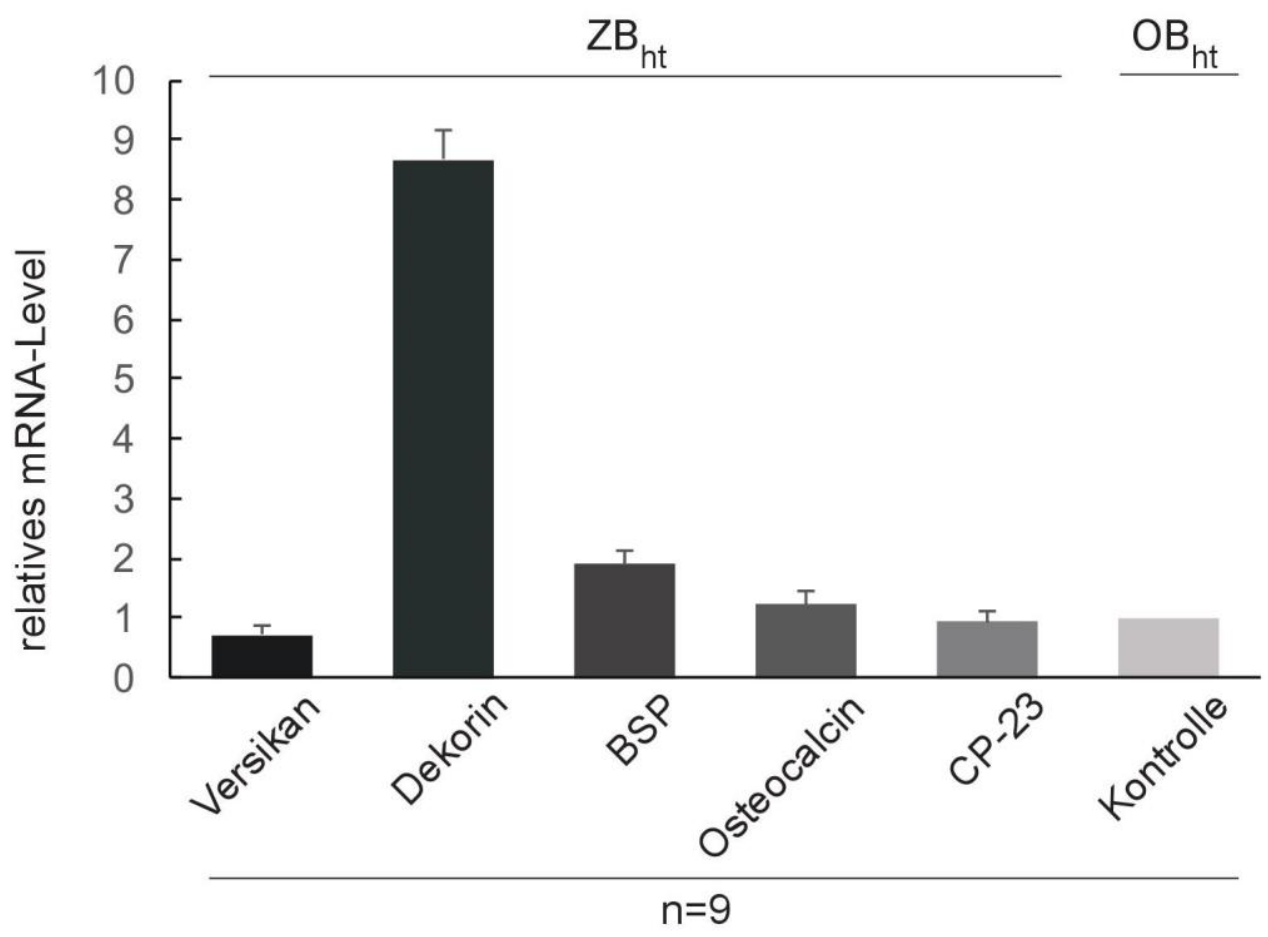

\section{Abb. 6: Relatives mRNA-Level undifferenzierter Zementoblasten von Protei- nen der extrazellulären Matrix}

In Abbildung 6 sind die unterschiedlichen Expressionslevel für Proteine, die laut Literatur besonders typisch sind für Zellen der osteoblastären Zelllinie, aber auch in Zementoblasten $\left(\mathrm{ZB}_{\mathrm{ht}}\right) \mathrm{zu}$ finden sind, dargestellt. Besonders Dekorin, welches neben Versikan zu den PG gezählt wird, zeigt ein hohes Expressionslevel. CP-23, welches als Markerprotein für Zement angesehen wird, fand sich auch in der Kontrolle, den Osteoblasten $\left(\mathrm{OB}_{\mathrm{ht}}\right)$ aus dem Alveolarkamm. Die Ergebnisse belaufen sich dabei auf die Mittelwerte im Vergleich zur Kontrolle. Die Fehlerbalken beschreiben die Standardabweichung. Die Nummer der Replikate ist $\mathrm{n}$.

Zusätzlich zu den mRNA-Leveln der Proteine, die in Abbildung 5 und 6 dargestellt sind, wurde mittels QPCR versucht, auch das mRNA-Level von RANKL, Sklerostin, und der ALP zu ermitteln. Zementoblasten zeigten auf mRNA-Ebene jedoch keine Expression. 
3.4.2 Relatives mRNA-Level osteogen differenzierter Zementoblasten

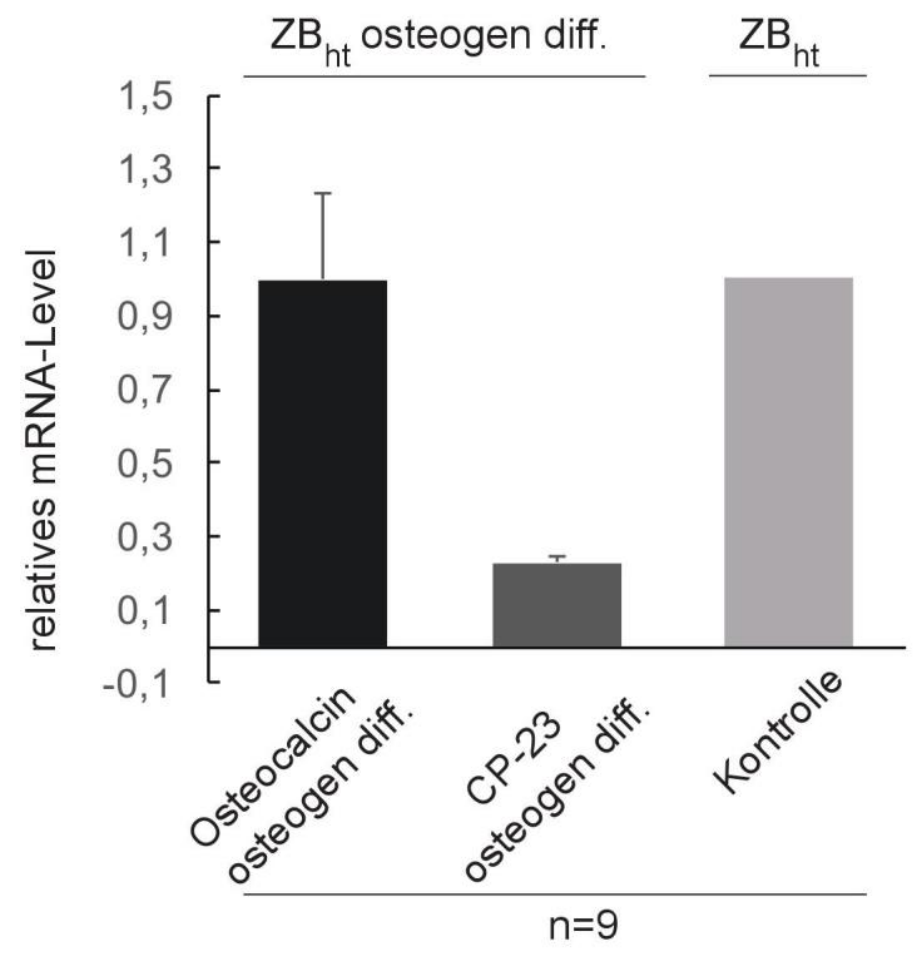

\section{Abb. 7: Relatives mRNA-Level osteogen differenzierter Zementoblasten von Osteocalcin und CP-23}

Abbildung 7 zeigt die Expressionslevel osteogen differenzierter Zementoblasten im Vergleich zu nicht differenzierten Zementoblasten von Osteocalcin und CP-23. Nicht osteogen differenzierte Zementoblasten bilden die Kontrolle. Es ist zu sehen, dass das relative mRNA-Level von Osteocalcin in den osteogen differenzierten Zementoblasten in etwa gleich ist und das mRNA-Level von CP-23 etwa auf ein Drittel bis Viertel gesunken ist. Die Ergebnisse belaufen sich dabei auf die Mittelwerte im Vergleich zur Kontrolle. Die Fehlerbalken beschreiben die Standardabweichung. Die Nummer der Replikate ist $\mathrm{n}$.

Auch bei den differenzierten Zementoblasten wurde versucht eine Expression von RANKL, Sklerostin und der ALP auf mRNA-Ebene nachzuweisen.

Differenzierte Zementoblasten zeigten nur bei Sklerostin eine Expression. Da die herangezogenen Kontrollzellen jedoch keine Sklerostin-Expression zeigten, ist eine statistische Auswertung nicht möglich. 


\subsection{Ergebnisse der Western Blots}

Die Genexpressionen von Kollagen Typ I und den beiden Transkriptionsfaktoren RUNX2 und SOX9 konnten mittels Western Blot erfolgreich auf Proteinebene nachgewiesen werden. Als Kontrollgruppe dienten immortalisierte CPCs. Die Zellen für den Versuch wurden noch vor Übersteigung einer Konfluenz von 70 \% geerntet. In den Abbildungen 8, 9 und 10 sieht man zum einen eine Übertragung der Proteine aus dem Gel auf die PVDF-Membran und zum anderen die anschließend darauffolgende Coomassie-Färbung. Weiterhin ist die positiv ausgefallene Immunreaktion für die jeweiligen Proteine als Bande auf der PVDF-Membran zu sehen. Hier zeigen sich die Banden mit ihrer jeweils typischen Höhe von ca. $150 \mathrm{kDa}$ für Kollagen Typ I, 55 bis $62 \mathrm{kDa}$ für RUNX2 und $55 \mathrm{kDa}$ für SOX9. Als Housekeeping-Gen wurde in den hier gezeigten Western Blots GAPDH eingesetzt. Die Proteinbande für GAPDH befindet sich auf der dafür typischen Höhe von 38 bis $40 \mathrm{kDa}$. GAPDH diente als Ladungskontrolle, damit das Proteinlevel zwischen den CPCs und den Zementoblasten gegen GAPDH normalisiert werden konnte, um anschließend ausgewertet zu werden. Alle drei Nachweise können als signifikant betrachtet werden $\left({ }^{*}<0,05\right)$. 


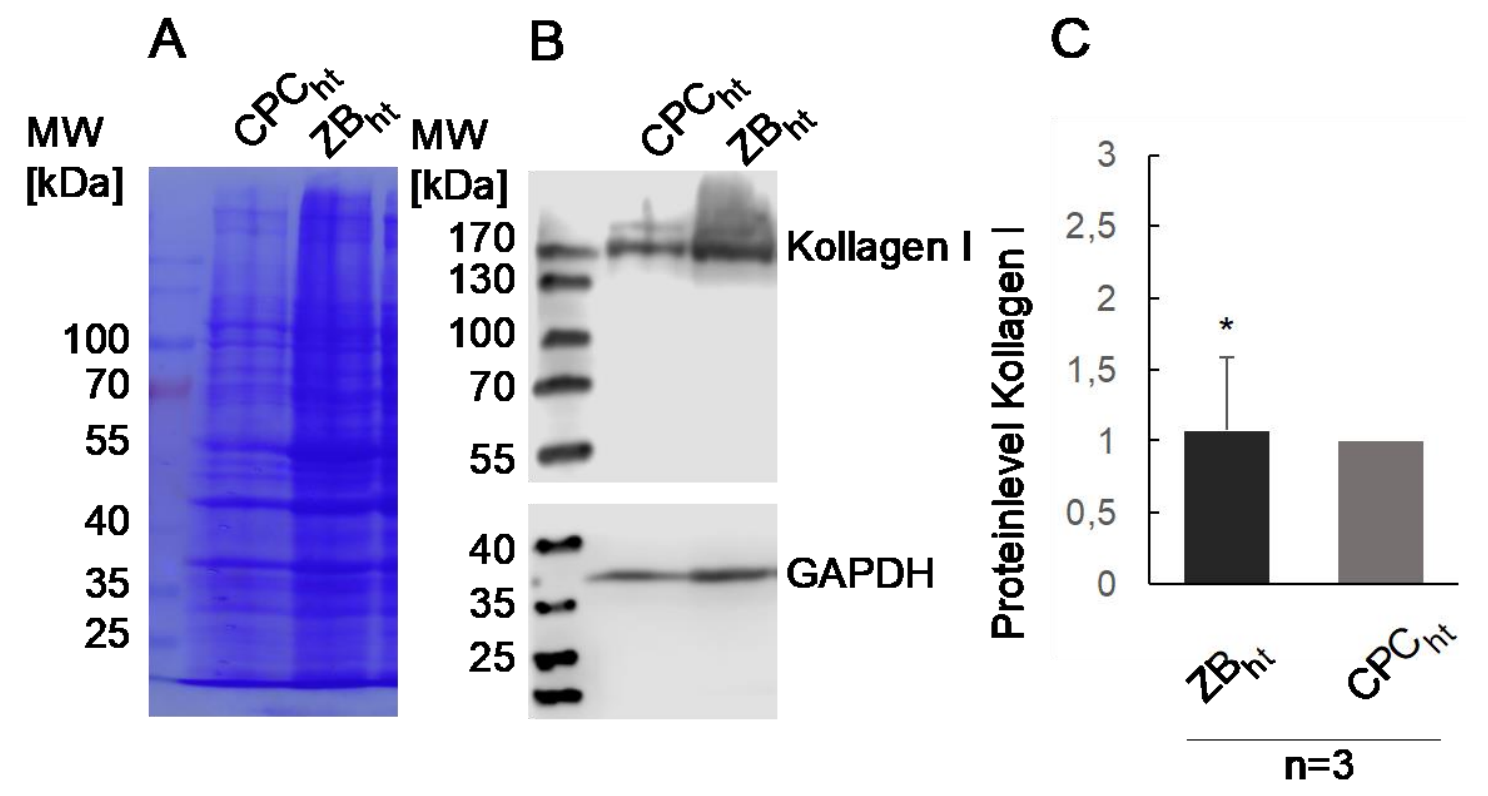

\section{Abb. 8: Nachweis von Kollagen Typ I auf Proteinebene}

Von links nach rechts wurden aufgetragen: Marker, CPCs (CPCht) und Zementoblasten (ZBht).

A: Coomassie-Färbung des Western Blots. B: Nachweis von Kollagen Typ I auf Proteinebene. Zu sehen sind jeweils die Proteinbanden für Kollagen Typ I bei den CPCs und den Zementoblasten. Die Proteinbanden für Kollagen Typ I verlaufen auf einer für sie charakteristischen Höhe von ca. $150 \mathrm{kDa}$. Ebenfalls dargestellt ist die Proteinbande für GAPDH auf Höhe von ca. 38 kDA. C: Quantitative Auswertung von Kollagen Typ I auf Proteinebene im Vergleich zur Kontrolle. Die Ergebnisse belaufen sich dabei auf die Mittelwerte von drei getrennten Durchläufen $(n=3)$. Der Fehlerbalken beschreibt die Standardabweichung. Die Signifikanz wurde dabei nach folgendem Maßstab festgelegt: ${ }^{*}=P<0,05,{ }^{* *}=P<0,01$. 

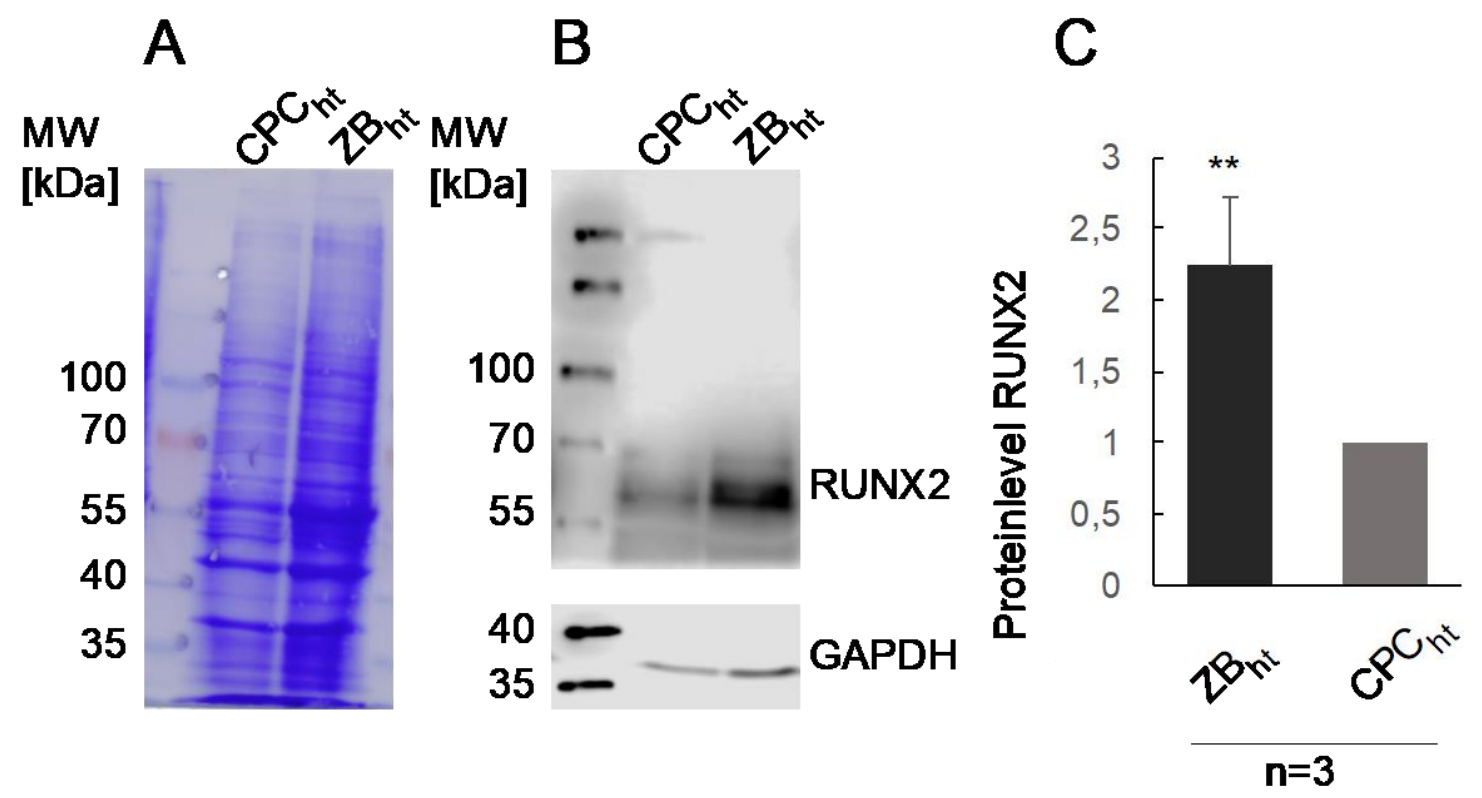

\section{Abb. 9: Nachweis von RUNX2 auf Proteinebene}

Von links nach rechts wurden aufgetragen: Marker, CPCs $\left(\mathrm{CPC}_{\mathrm{ht}}\right)$ und Zementoblasten $\left(\mathrm{ZB}_{\mathrm{ht}}\right)$.

A: Coomassie-Färbung des Western Blots. B: Nachweis von RUNX2 auf Proteinebene. RUNX2 besitzt ein Molekulargewicht von ca. 55-62 kDa. Ebenfalls dargestellt ist der Nachweis von GAPDH auf Proteinebene. GAPDH besitzt ein Molekulargewicht von ca. $38 \mathrm{kDa}$ und diente als Ladungskontrolle. C: Quantitative Auswertung von RUNX2 auf Proteinebene im Vergleich zur Kontrolle. Die Ergebnisse belaufen sich dabei auf die Mittelwerte von drei getrennten Durchläufen ( $n=3)$. Der Fehlerbalken beschreibt die Standardabweichung. Die Signifikanz wurde dabei nach folgendem Maßstab festgelegt: ${ }^{* *}=P<0,01$. 


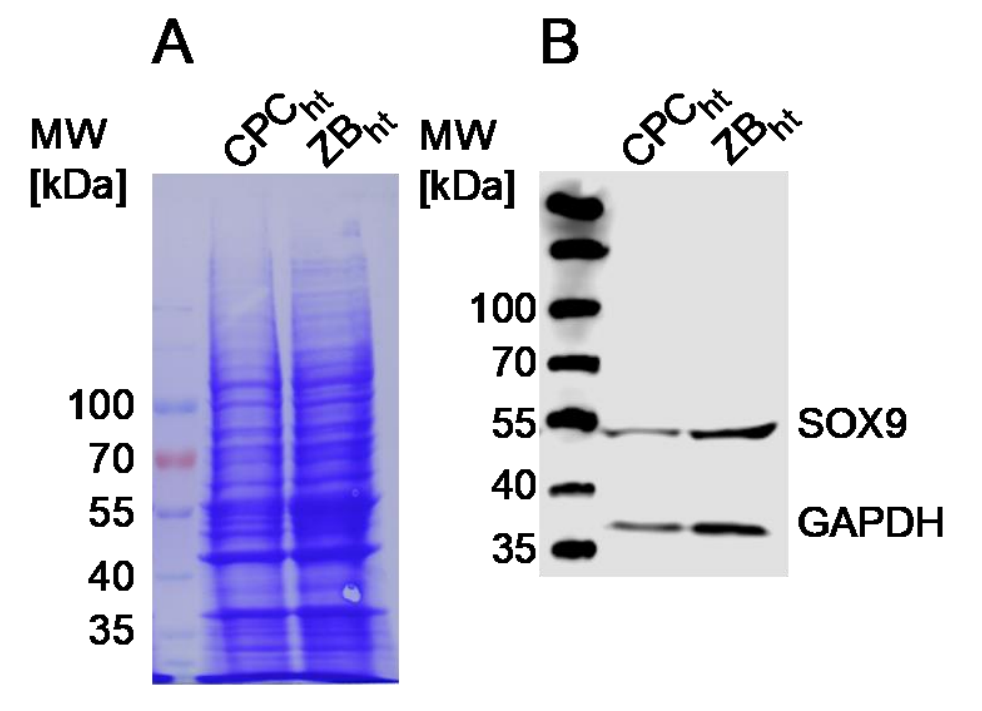

C

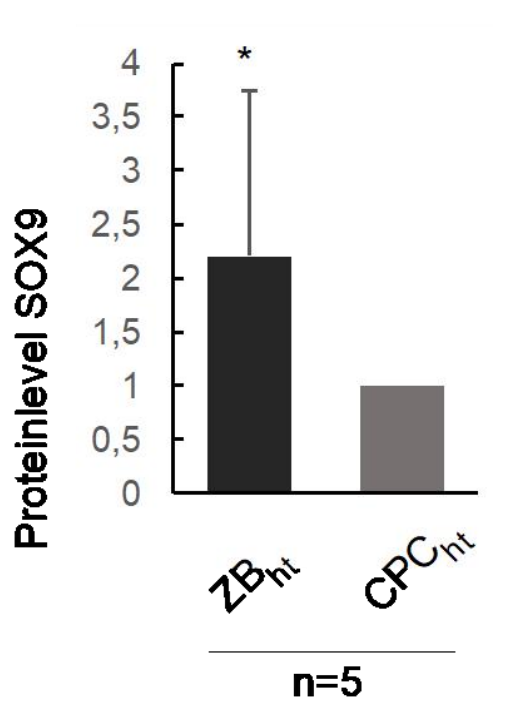

\section{Abb. 10: Nachweis von SOX9 auf Proteinebene}

Von links nach rechts wurden aufgetragen: Marker, CPCs $\left(\mathrm{CPC}_{\mathrm{ht}}\right)$ und Zementoblasten $\left(\mathrm{ZB}_{\mathrm{ht}}\right)$.

A: Coomassie-Färbung des Western Blots. B: Nachweis von SOX9 auf Proteinebene. SOX9 besitzt ein Molekulargewicht von ca. $55 \mathrm{kDa}$. Ebenfalls dargestellt ist der Nachweis von GAPDH auf Proteinebene. GAPDH besitzt ein Molekulargewicht von ca. $38 \mathrm{kDa}$ und diente als Ladungskontrolle. C: Quantitative Auswertung von RUNX2 auf Proteinebene im Vergleich zur Kontrolle. Die Ergebnisse belaufen sich dabei auf die Mittelwerte von fünf getrennten Durchläufen $(n=5)$. Der Fehlerbalken beschreibt die Standardabweichung. Die Signifikanz wurde dabei nach folgendem Maßstab festgelegt: ${ }^{*}=\mathrm{P}<0,05$. 


\subsection{Immunzytochemischer Nachweis verschiedener Proteine}

Mithilfe der Immunfluoreszenz konnten folgende Proteine erfolgreich nachgewiesen werden: Kollagen Typ I, Kollagen Typ III, RUNX2, SOX9, Dekorin, Osteopontin und CP-23.

Der Versuch wurde nach einer Anwachs- und Vermehrungsphase von ca. einer Woche durchgeführt. Die Immunfluoreszenzfärbungen erfolgten innerhalb eines Durchlaufes immer unter denselben Bedingungen. Die Zellkerne wurden mit dem Fluoreszenzfarbstoff DAPI markiert. Dieser lässt Zellkerne blau erscheinen. In Abbildung 10, 11 und 12 ist die Fluoreszenz von CP-23, Kollagen Typ I und III, Dekorin und Osteopontin dargestellt. Es ist zu sehen, dass die rote Fluoreszenzfarbe vor allem ausserhalb des Zellkerns, im Zytoplasma lokalisiert ist. Im Vergleich dazu zeigen die Abbildungen 13 und 14 die Fluoreszenz von RUNX2 und SOX9. Hier ist neben dem Overlay auch die einzelne Markierung der Zellkerne mittels DAPI in blau und die Proteinmarkierung in roter Farbe mithilfe des Fluoreszenzfarbstoffes Alexa Fluor 555, dargestellt. Abbildung 13 und 14 zeigen somit, dass die beiden Transkriptionsfaktoren RUNX2 und SOX9 im Bereich des Zellkerns lokalisiert sind. Alle Aufnahmen wurden mit einer 20-fachen Vergrößerung aufgenommen. In der jeweils passenden Negativkontrolle ist keine Fluoreszenz erkennbar. 

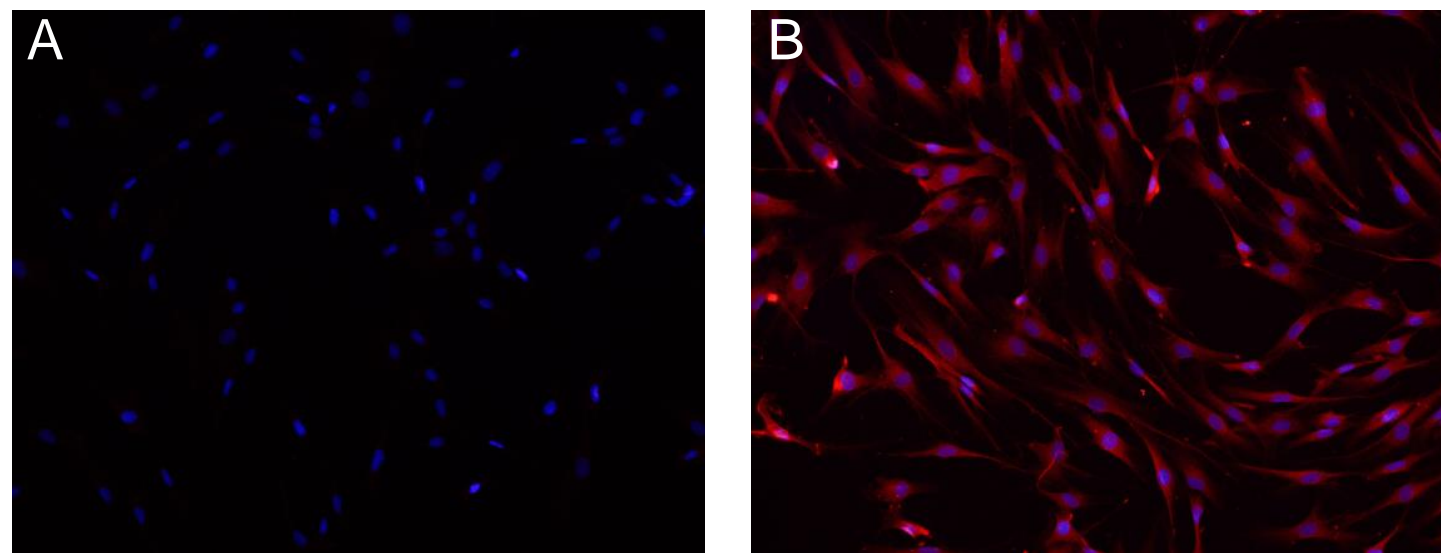

\section{Abb. 11: Immunzytochemische Darstellung von CP-23}

Abbildung 11 zeigt den immunzytochemischen Nachweis von CP-23 in Zementoblasten. Die Aufnahmen erfolgten mit einer 20-fachen Vergrößerung. Die Zellen befanden sich bei der Durchführung des Versuches in Passage 15 (P15). Durch die rote Fluoreszenzfärbung des Proteins ist zu sehen, dass das Protein CP-23 vor allem im Zytoplasma lokalisiert ist. A: Negativkontrolle. B: Overlay und Fluoreszenzmarkierung von CP-23 in roter Farbe mit Alexa Fluor 555.
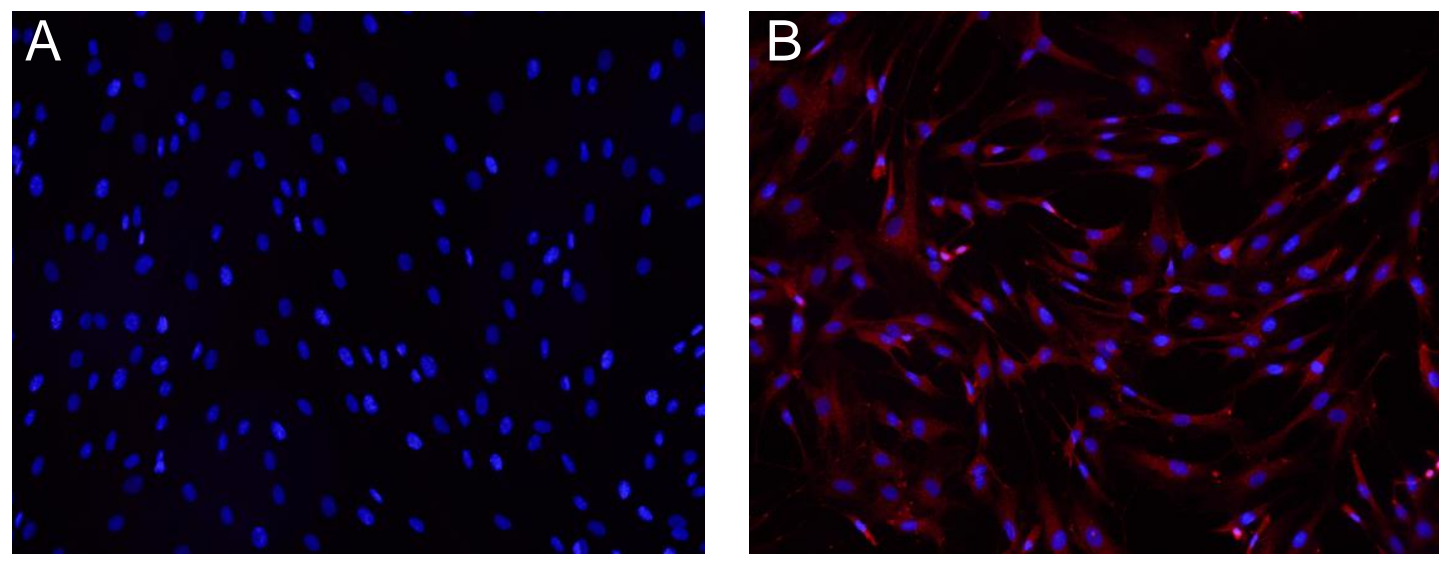

\section{Abb. 12: Immunzytochemische Darstellung von Kollagen Typ III}

Abbildung 12 zeigt den immunzytochemischen Nachweis von Kollagen Typ III in Zementoblasten. Die Aufnahmen erfolgten mit einer 20-fachen Vergrößerung. Die Zellen befanden sich bei der Durchführung des Versuches in Passage 15 (P15). Durch die rote Fluoreszenzfärbung des Proteins ist zu sehen, dass das Protein Kollagen Typ III vor allem im Zytoplasma lokalisiert ist.

A: Negativkontrolle. B: Overlay und Fluoreszenzmarkierung von Kollagen Typ III in roter Farbe mit Alexa Fluor 555. 

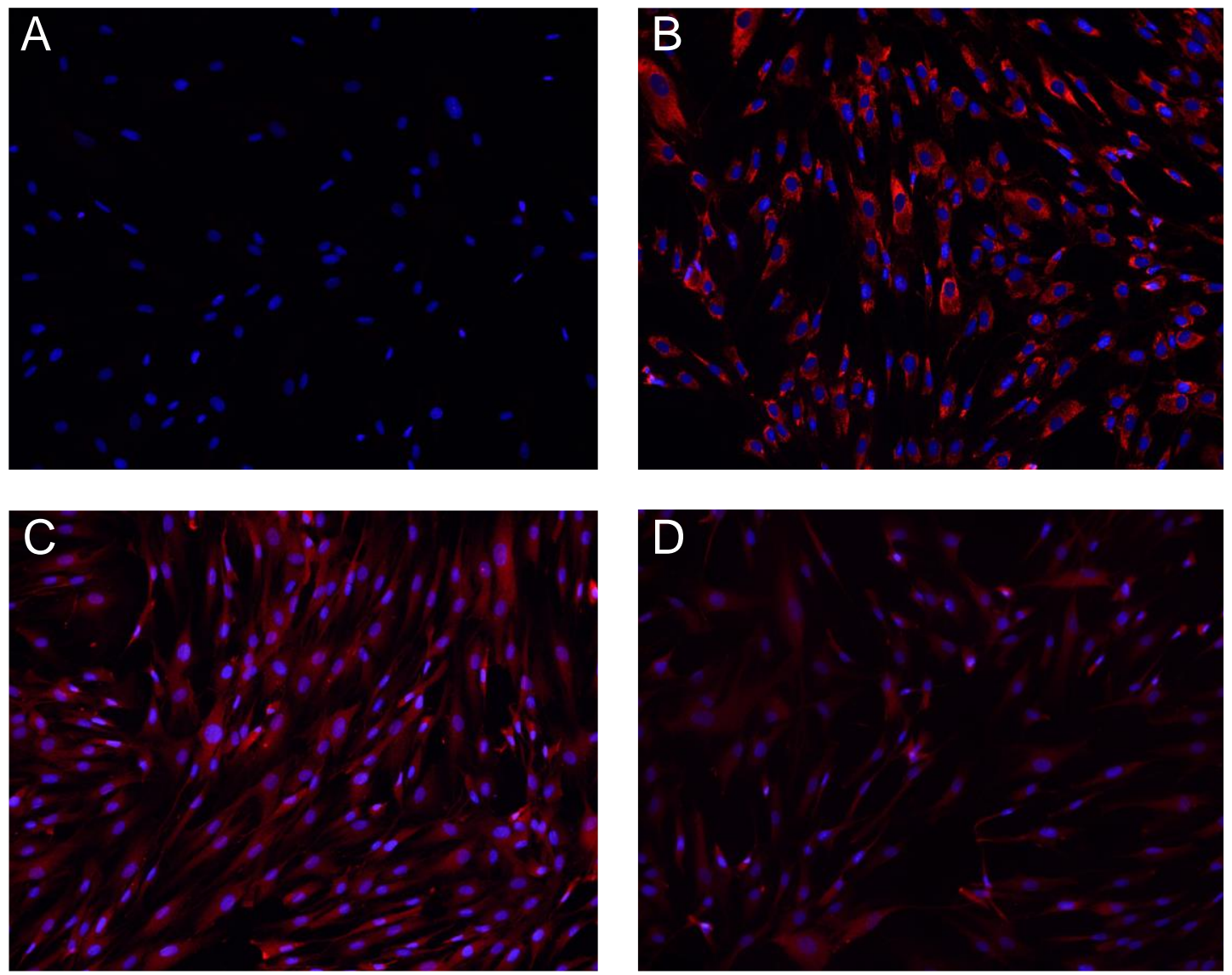

Abb. 13: Immunzytochemischer Nachweis von Kollagen Typ I, Dekorin und Osteopontin

Abbildung 13 zeigt den immunzytochemischen Nachweis von Kollagen Typ I, Dekorin und Osteopontin. Die Aufnahmen erfolgten mit einer 20-fachen Vergrößerung. Die Zellen befanden sich bei der Durchführung des Versuches in Passage 15 (P15). Durch die rote Fluoreszenzfärbung des Proteins ist zu sehen, dass die Proteine Kollagen Typ I, Dekorin und Osteopontin vor allem im Zytoplasma lokalisiert sind.

A: Negativkontrolle. B: Overlay und Fluoreszenzmarkierung von Kollagen Typ I in roter Farbe mit Alexa Fluor 555. C: Overlay und Fluoreszenzmarkierung von Dekorin in roter Farbe mit Alexa Fluor 555. D: Overlay und Fluoreszenzmarkierung von Osteopontin in roter Farbe mit Alexa Fluor 555. 

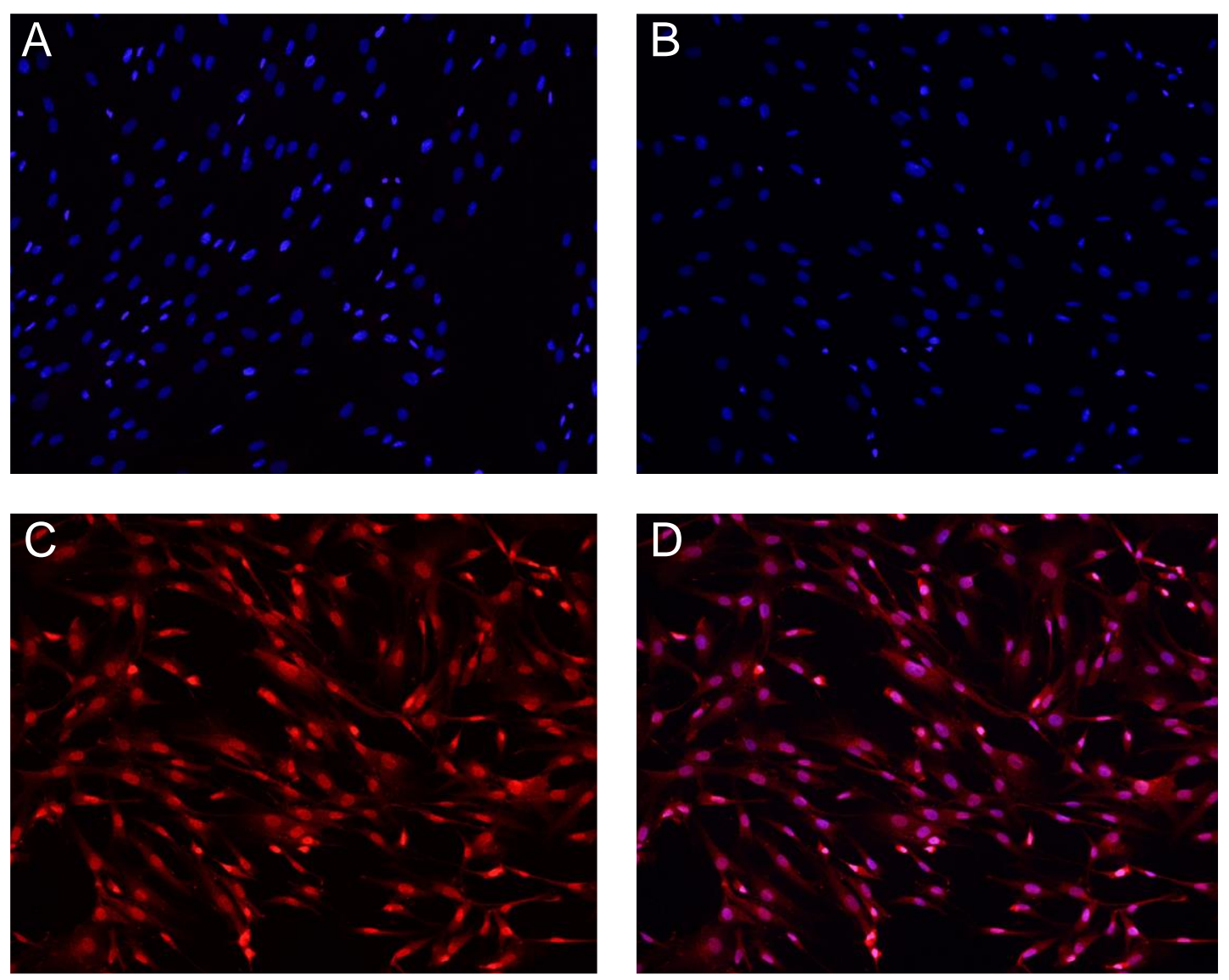

\section{Abb. 14: Immunzytochemischer Nachweis von RUNX2}

Abbildung 14 zeigt den immunzytochemischen Nachweis von RUNX2. Die Aufnahmen erfolgten mit einer 20-fachen Vergrößerung. Die Zellen befanden sich bei der Durchführung des Versuches in Passage 15 (P15). Durch die rote Fluoreszenzfärbung des Proteins ist zu sehen, dass RUNX2 vor allem im Zellkern lokalisiert ist.

A: Negativkontrolle. B: Markierung der Zellkerne in blau mit dem Fluoreszenzfarbstoff DAPI.

C: Proteinmarkierung von RUNX2 in rot mit dem Fluoreszenzfarbstoff Alexa Fluor 555. D: Overlay. 

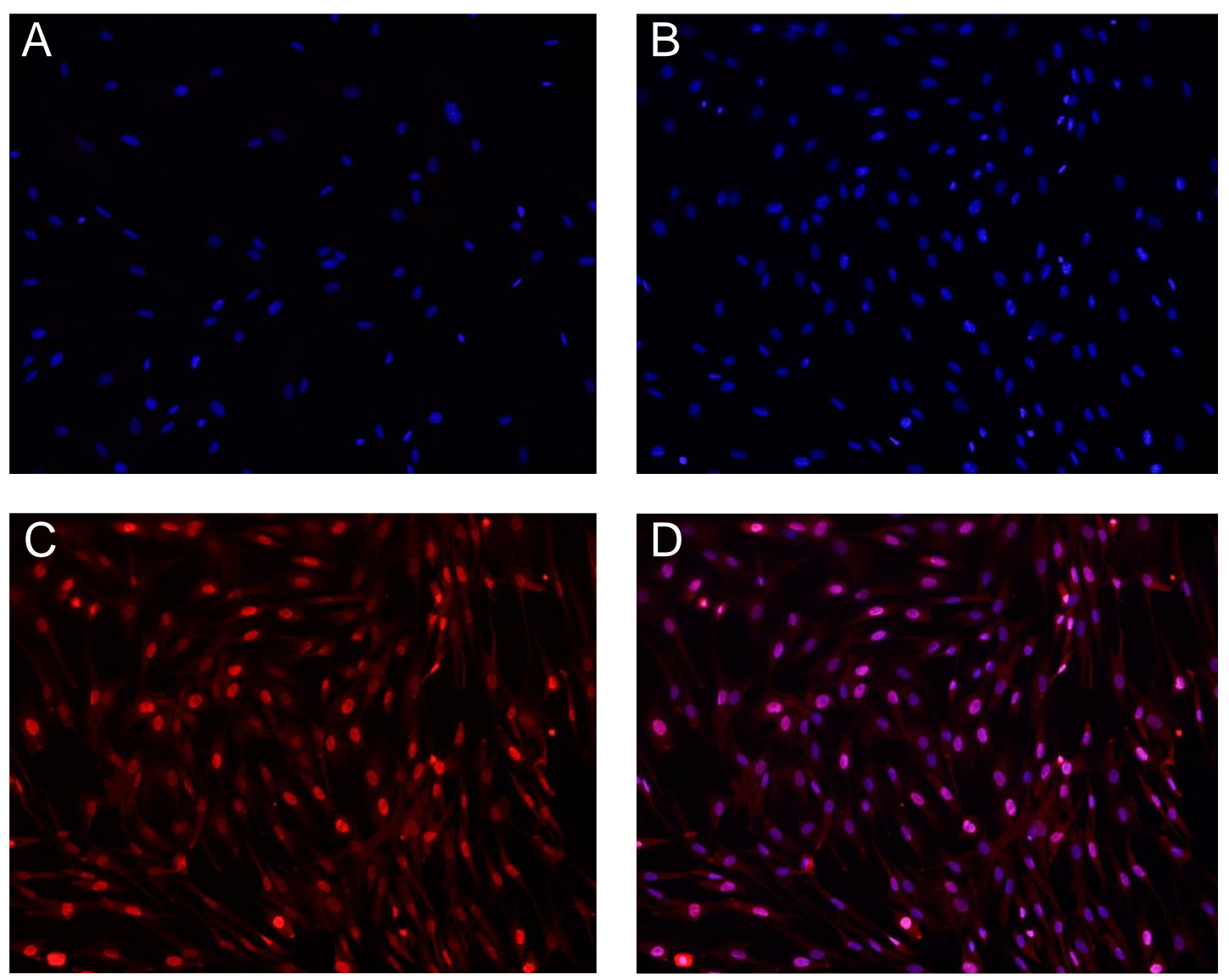

\section{Abb. 15: Immunzytochemischer Nachweis von SOX9}

Abbildung 15 zeigt den immunzytochemischen Nachweis von SOX9. Die Aufnahmen erfolgten mit einer 20-fachen Vergrößerung. Die Zellen befanden sich bei der Durchführung des Versuches in Passage 15 (P15). Durch die rote Fluoreszenzfärbung des Proteins ist zu sehen, dass SOX9 vor allem im Zellkern lokalisiert ist.

A: Negativkontrolle. B: Markierung der Zellkerne in blau mit dem Fluoreszenzfarbstoff DAPI.

C: Proteinmarkierung von SOX9 in rot mit dem Fluoreszenzfarbstoff Alexa Fluor 555. D: Overlay. 


\subsection{Nachweis verschiedener intrazellulärer Proteine durch die FACS-Analyse}

Nachdem die kultivierten Zellen geerntet worden waren, wurden 4,5 x $10^{5}$ Zellen auf einige intrazellulären Proteine mittles FACS-Analyse untersucht. Folgende Proteine konnten erfolgreich nachgewiesen werden: Kollagen Typ I, RUNX2, SOX9 und Osteonektin. Es wurden mindestens drei Durchläufe pro Protein durchgeführt.

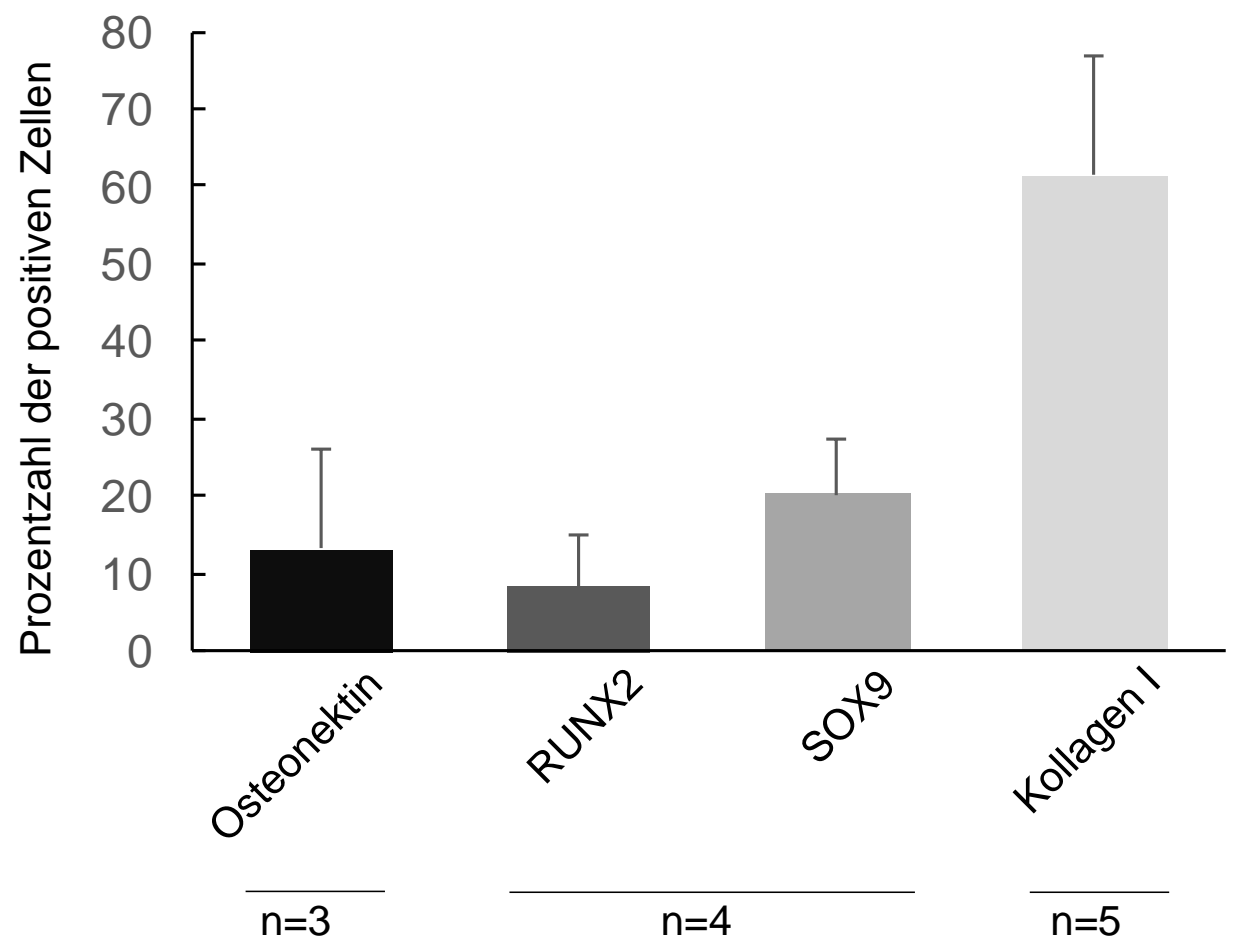

\section{Abb. 16: FACS-Analyse intrazellulärer Proteine}

In Abbildung 16 sind die Ergebnisse der FACS-Analyse für Osteonektin, RUNX2, SOX9 und Kollagen Typ I graphisch dargestellt. Die Fehlerbalken beschreiben die Standardabweichung. Die Nummer der Replikate ist $\mathrm{n}$. 


\section{Diskussion}

Aufgrund der besonderen Bedeutung des Zementes für die parodontale Gesundheit wurde der Fokus dieser Arbeit auf die Gewinnung, Immortalisierung und eine anschließende Charakterisierung von humanen Zementoblasten, den Zement-bildenden Zellen gelegt. Zwar gelang es im Jahr 2006 einer Forschungsgruppe, humane Zementoblasten zu immortalisieren und auf bestimmte Proteine auf mRNA-Level zu untersuchen (Kitagawa et al. 2006), allerdings fehlte eine weiterführende Untersuchung der immortalisierten Zementoblasten durch unterschiedliche Methoden. Des Weiteren beschäftigte sich diese Studie nur mit der Untersuchung einer begrenzten Anzahl an Proteinen, die laut Literatur für Knochen und Zement typisch zu sein scheinen. Im Rahmen der vorliegenden Arbeit konnten viele wichtige Zementproteine in vitro zum ersten Mal nicht nur mittels qRT-PCR, sondern auch im Western Blot, in der Immunfluoreszenz und in der FACS-Analyse nachgewiesen werden. Es zeigten sich teilweise deutliche Unterschiede im Expressionsverhalten der unterschiedlichen Matrix-Proteine. Schon vor Jahren begann eine Debatte um die Zugehörigkeit der Zementoblasten und inwieweit sich Zementoblasten und Zement von den Osteoblasten und dem Knochen unterscheiden (Bosshardt 2005; Zhao et al. 2016b). Es stellt sich deshalb auch weiterhin die Frage, ob Zementoblasten eine eigenständige Zellart sind oder nur im Zement positionierte Osteoblasten, die von ihren umgebenden Umweltfaktoren reguliert werden (Kitagawa et al. 2006). Die Idee, dass Zementoblasten vielleicht sogar verstärkt Markerproteine, die eigentlich dem osteoblastären Charakter zugewiesen werden, exprimieren, begleitete die Arbeit von Anfang an. Deswegen wird im Rahmen dieser Arbeit auch diskutiert, ob Zement-spezifische Markerproteine, wie beispielsweise das CP-23, tatsächlich als Markerproteine betrachtet werden können.

\subsection{Klinische Bedeutung}

Fortgeschrittene parodontale Erkrankungen führen zu einem bedeutenden Verlust von Zement und Knochen (Pihlstrom et al. 2005). Aufgrund des steigenden Bestrebens, Zähne durch neue Therapieansätze so lange wie möglich zu erhalten und 
auch neue Therapien für die natürliche Regeneration von Zähnen zu entwickeln, steigt das Interesse, die Zahnhalteapparat-bildenden Gewebe (beispielsweise PDL, Alveolarknochen, Gingiva und Wurzelzement) vollständig zu erforschen. Vor allem das Wurzelzement scheint beim Regenerationsprozess eine entscheidende Rolle zu spielen (MacNeil und Somerman 1993). Die Hauptfunktion des gesunden Zementes ist die Verankerung der parodontalen Fasern an der Wurzeloberfläche. Nach einer parodontalen Erkrankung und dem dadurch oft verbundenen Verlust dieses Attachments unterstützt das Wurzelzement den regenerativen Prozess (Knox und Aukhil 1988). Sowohl das Fehlen von Zement als auch defektes Zement laufen auf eine parodontale Fehlfunktion, Zahnfunktionsstörungen und Zahnverlust hinaus. Obwohl Zement regeneriert werden kann, sind aktuelle therapeutische Möglichkeiten beschränkt, und die Ergebnisse bleiben unvorhersehbar (Bosshardt und Sculean 2009). Einige Studien gehen sogar davon aus, dass ohne die Präsenz des Zementes ein gesundes Parodontium nicht wiederhergestellt werden kann (Lindskog und Blomlöf 1983; Page und Baab 1985). Die wirksame Behandlung dieser Gegebenheiten verlässt sich auf die Fähigkeit, die zugrunde liegende Infektion oder Pathologie, die zu Gewebeverlust führt, zu beseitigen und neues Ersatzgewebe zu regenerieren. Dies kann durch die Förderung einer Differenzierung von im Gewebe sitzenden Stamm- bzw. Progenitorzellen mit einer Kombination von einsetzbarem Biomaterial und Wachstumsfaktoren erreicht werden (Chen et al. 2010). Obwohl Forschung an Osteoprogenitorzellen und deren mesenchymalen Stammzellen umfassend betrieben wurde, ist im Vergleich dazu recht wenig über die Differenzierung von Zementoblasten bekannt (Matthews et al. 2016). Um parodontole Erkrankungen besser therapieren zu können und Geweberegeneration vorantreiben zu können, bedarf es jedoch eines besseren Verständnisses über die Zahnhalteapparat-bildenden Gewebe, im Speziellen dem wenig erforschtem Zement.

\subsection{Diskussion der Expression der Kollagene Typ I und III}

Die Kollagensynthese spielt bei der Zementbildung eine entscheidende Rolle. Die Kollagene bilden im Zement quer gestreifte Fibrillen, die den Mineralkristallen später als Baugerüst dienen. Dadurch wird eine biologische Mineralisation induziert. Die Strukturintegrität wird dabei auch nach Abschluss der Mineralisation aufrechterhalten (Yamamoto et al. 2016). Die Aussagen in der Literatur über Kollagen Typ I und 
III (Birkedal-Hansen et al. 1977; Christner et al. 1977; Bosshardt und Selvig 1997) stimmen mit den Ergebnissen dieser Arbeit auf mRNA-Level überein. Im Rahmen dieser Arbeit ist es gelungen, Kollagen Typ III in humanen Zementoblasten mittels qRT-PCR und in der Immunfluoreszenz nachzuweisen. Der Nachweis im Western Blot und in der FACS-Analyse war dagegen erfolglos. Kollagen Typ I konnte zum ersten Mal sowohl in der qRT-PCR als auch im Western Blot, in der Immunfluoreszenz und in der FACS-Analyse nachgewiesen werden.

\subsection{Proteoglykane als Bestandteile der extrazellulären Matrix im humanen Zement}

PG sind komplexe Makromoleküle, bestehend aus einem Kernprotein, an welches GAG kovalent gebunden sind. Immunhistochemisch gesehen werden Dermatansulfat, Chondroitinsulfat und Keratansulfat als GAG betrachtet. Bezüglich der unterschiedlichen Typen an PG wird Versikan als großes PG und Dekorin und Lumikan als kleine PG bezeichnet. Es wird angenommen, dass sie nur in zellulärem Zement vorkommen (Ababneh et al. 1998; Ababneh et al. 1999). Es existiert die Annahme, dass PG die Mineralisation von Kollagenfibrillen inhibieren, indem sie bestimmte Bereiche der Kollagenfasern besetzen, die eigentlich dazu vorgesehen sind, mit Kristallen aus Hydroxylapatit aufgefüllt zu werden. Folglich ist der Gehalt an PG nach Mineralisation der Zement-Matrix geringer (Ababneh et al. 1998). Eine veränderte Expression von PG im erkrankten oder auch älteren Zement könnte mit der verringerten Fähigkeit zur parodontalen Regeneration nach beispielsweise einer Parodontitis assoziiert sein. Die Wahrscheinlichkeit, an einer Parodontits zu erkranken, steigt auch mit zunehmendem Alter. Zur Unterstützung dieser These haben etliche Studien gezeigt, dass gesundes Zement die Migration, das Attachment, das Wachstum und die Synthese von PDL-Fibroblasten fördert (Miki et al. 1987; Somerman et al. 1987; Nishimura et al. 1989; McAllister et al. 1990; Ogata et al. 1994). Außerdem scheint es die Differenzierung von mesenchymalen Zellen in Zementoblasten, Osteoblasten und Fibroblasten zu veranlassen (Nishimura et al. 1995).

Interessant ist die hohe Expression von Dekorin auf mRNA-Level. Dekorin ist ein Mitglied einer ausgedehnten und weit verteilten Gruppe von Leucin reichen PG, die eine wichtige Funktion beim Gewebeaufbau besitzen. Die Hauptaufgabe dieses 
sog. Kollagen-bindenden Proteins ist die Kontrolle der Kollagenfasersynthese (lozzo und Murdoch 1996). Mäuse, die einen Gendefekt bei Dekorin aufwiesen, waren zwar überlebensfähig, zeigten jedoch stark fragile Haut mit einem deutlich reduzierten Dehnungszustand. Grund hierfür war die Ausbildung abnormaler Kollagenfasern (Danielson et al. 1997). Die Tatsache, dass Dekorin unabdingbar ist für eine einwandfreie Synthese und Verteilung von Kollagenfasern, würde sein hohes Expressionslevel, welches mittels qRT-PCR ermittelt wurde, erklären.

Versikan ist ein langes Chondroitinsulfat-PG welches in einer Vielzahl von Geweben präsent ist und die Fähigkeit besitzt Hyaluron zu binden. Es ist bekannt, dass Versikan an der Gewebebildung mitbeteiligt ist und dem Gewebe eine Grundelastizität verleiht (Wight 2002). Zahlreiche Studien berichten über das Vorkommen von Versikan in der Zahnpulpa (Harlamb und Messer 1996; Yamauchi et al. 1997; Shibata et al. 2002), dem Wurzelzement (Ababneh et al. 1999; Cheng et al. 1999) und dem PDL (Larjava et al. 1992; Sato et al. 2002). PG und insbesondere Versikan scheinen eine Rolle beim Zahndurchbruch zu spielen (Marks und Schroeder 1996; Sone et al. 2005). Während aller Phasen des Zahndurchbruchs konnte Versikan in der Zahnpulpa, den Odontoblasten, dem Alveolarknochen und dem Wurzelzement nachgewiesen werden. Sowohl in Zementoblasten als auch in Zementozyten stieg sogar das Signal für Versikan (Sone et al. 2005).

Während, wie bereits erwähnt, das PG Dekorin ein hohes Expressionslevel bei der qRT-PCR zeigt, fällt das Expressionslevel für Versikan nur gering aus. Das relative mRNA-Level für Versikan liegt unter dem Level der Kontrolle, in diesem Fall den Osteoblasten. Das PG Versikan wurde im Ramen dieser Arbeit nur mittels qRT-PCR nachgewiesen.

\subsection{Die beiden Transkriptionsfaktoren RUNX2 und SOX9}

Das RUNX2 Gen ist $220 \mathrm{~kb}$ lang (Levanon et al. 1994) und besitzt acht Exons (Geoffroy et al. 1998; Xiao et al. 1998; Quack et al. 1999). RUNX2 ist ein Transkriptionsfaktor und ist ein Mitglied der runt-related transcription factor (RUNX)-Genfamilie. Diese Gene, die RUNX1, RUNX2 und RUNX3 genannt werden, besitzen eine 
hohe Aminosäurehomologie (Kundu et al. 2002). Diese Transkriptionsfaktoren enthalten eine RUNT-Proteindomäne, die zum einen entscheidend für eine DNA-Bindung ist und zum anderen eine Voraussetzung für eine Protein-Protein-Interaktion darstellt (Schroeder et al. 2005). RUNX2 ist das früheste und spezifischste Markergen welches man bei der Osteoblasten-Differenzierung kennt (Ducy et al. 1997; Ducy et al. 1999; Franceschi 1999; Ito 1999). RUNX2 ist für die Knochenbildung unentbehrlich (Ducy et al. 1997). Aber nicht nur im Knochen spielt RUNX2 eine entscheidende Rolle, sondern auch in der Zahnentwicklung und dem Zahndurchbruch und konnte erfolgreich auch im Zement nachgewiesen werden (Bronckers et al. 2001; Chen et al. 2002; Kobayashi et al. 2006). RUNX2 ist demnach erforderlich für die Differenzierung von Mineral-bildenden Zellen wie den Osteoblasten, den Zementoblasten und Odontoblasten (D'Souza et al. 1999; Aberg et al. 2004). Während einige Autoren RUNX2 auch in Zementozyten nachweisen konnten, zeigen andere Angaben in der Literatur, dass RUNX2 nicht in Zementozyten vorzufinden ist. Ob nun RUNX2 in Zementozyten auch eine Rolle spielt, bleibt deshalb weiterhin umstritten (Bronckers et al. 2001; Hirata et al. 2009). Ziel dieser Arbeit war auch der Nachweis von RUNX2 in Zementoblasten in vitro. RUNX2 konnte bei der qRT-PCR, dem Western Blot der Immunfluoreszenz und der FACS-Analyse erfolgreich nachgewiesen werden.

SOX9 ist ebenfalls ein Transkriptionsfaktor und gehört in die Gruppe der SOX-Proteine, die wiederum zur high-mobility-group- (HMG) Box-Familie gehören (Wegner 1999). Erstes Protein und Namensgeber dieser Gruppe von Transkriptionsfaktoren war das SRY-Protein (Gubbay et al. 1990). SOX9 wird i.d.R. mit Chondrozyten und Chondrogenese assoziiert, da es für die Bildung des Knorpelgewebes und die damit verbundene Ausdifferenzierung und Reifung der Chondrozyten unerlässlich ist (Bi et al. 1999; Akiyama et al. 2005; Kiefer 2007). SOX9 ist wichtig für die Kondensation mesenchymaler Zellen und spielt eine entscheidende Rolle bei der chondralen Ossifikation (Huang et al. 2001; Akiyama et al. 2002). In der craniofazialen Region wird SOX9 stark im Meckel-Knorpel, einer Knorpelspange des ersten Kiemenbogens, die später als Leitstruktur für die Anlage der Mandibula dient, exprimiert. Im späteren, embryonalen Entwicklungsstadium der Mandibula geht die SOX9-Expression zurück bzw. verschwindet vollständig (Yamashiro et al. 2004). Eine weitere For- 
schungsgruppe beschäftigte sich mit dem molekularen Hintergrund der Alveolarknochen-Entstehung und erforschte das osteogene Profil von mesenchymalen Zellen im frühen Bildungsstadium des Alveolarknochens und konnte SOX9 erfolgreich in der qRT-PCR und in der Immunfluoreszenz nachweisen (Minaříková et al. 2015). Während der Embryonalentwicklung des Alveolarknochens spielen mesenchymale Zellen des Zahnes also eine entscheidende Rolle (Diekwisch 2002; Diep et al. 2009). Bis zum heutigen Stand der Wissenschaft gibt es keine Nachweise oder Veröffentlichungen über eine SOX9-Expression in humanen Zementoblasten. Mit dem Hintergrund, dass die klassische Theorie der Zementogenese auf einer mesenchymalen Abstammung der Zementoblasten beruht, lässt sich gut erklären, dass SOX9 auch in Zementoblasten exprimiert wird. Zum ersten Mal ist es gelungen SOX9 erfolgreich im humanen Zement nachzuweisen. Vergleicht man die Ergebnisse der qRT-PCR mit den Ergebnissen des Western Blots, ist festzustellen, dass obwohl das relative mRNA-Level sehr gering ist und unter dem Expressionslevel der Kontrolle - den Osteoblasten - liegt, trotzdem laut Western Blot mehr Protein tatsächlich gebildet wird. Allerdings darf nicht vergessen werden, dass für die qRTPCR als Kontrolle Osteoblasten herangezogen wurden und im Western Blot CPCs als Kontrolle dienten.

\subsection{Diskussion über die typischen Matrix-Proteine Osteocal- cin, Bone Sialoprotein, Osteopontin und Osteonektin}

\section{Osteocalcin}

Osteocalcin kommt auch als Peptidhormon vor und findet sich in den meisten Wirbeltieren. Entscheidend ist Osteocalcin vor allem für den Knochenauf- und abbau. Seine hohe Affinität zu Hydroxylapatit und Kalzium erklärt auch seine wichtige Bedeutung beim Mineralisationsprozess (Raymond et al. 1999). Außerdem übernimmt Osteocalcin als Hormon beim Knochenmetabolismus eine wichtige endokrinologische Funktion (Karsenty und Ferron 2012; Karsenty und Oury 2012). Beim Zement wird die Einlagerung von Hydroxylapatit und somit auch der Mineralisationsprozess unter anderem von Osteocalcin reguliert (Nanci 2008). So kann sichergestellt werden, dass die Mineralisation sehr differenziert erfolgt und die einstrahlenden Shar- 
pey-Fasern zeitweise auch frei von Mineralisation bleiben (Radlanski 2011). Aufgrund der Tatsache, dass Zement ein mineralisiertes Gewebe ist, spielen die Adhäsionsmoleküle Osteopontin (Bosshardt et al. 1998; Sodek et al. 2002; Bosshardt et al. 2006) und BSP (Bosshardt et al. 1998; Bosshardt et al. 2006) bei der Zementbildung und vor allem beim Mineralisationsprozess ebenfalls eine wichtige Rolle. Die Mineralisationsprozesse des Zementes konnten bis heute nicht im Detail geklärt werden (Radlanski 2011). Osteocalcin konnte durch die qRT-PCR sowohl in undifferenzierten, humanen Zementoblasten als auch in osteogen differenzierten Zementoblasten nachgewiesen werden. Im Knochen steuert Osteocalcin die Aktivierung von Osteoklasten und somit auch die Knochenresorption und den damit verbundenen Remodellierungsprozess des Knochens (Davies 1996). Osteocalcin ist demnach ein Indikator für Osteoklasten und müsste bei einer osteogenen Differenzierung deutlich mehr exprimiert werden. Vergleicht man hierzu das relative mRNALevel vor und nach osteogener Differenzierung der Zementoblasten sieht man jedoch fast keinen Unterschied des mRNA-Levels. Dieses Ergebnis deutet darauf hin, dass die osteogene Differenzierung nicht angeschlagen hat. Als Schlussfolgerung kann vermutet werden, dass Zementoblasten sich eventuell grundsätzlich nicht osteogen differenzieren lassen.

\section{Osteopontin}

Das stark phosphorylierte Protein Osteopontin findet sich vor allem in stark mineralisiertem Gewebe und kommt deshalb auch hauptsächlich in der mineralisierten Matrix von Knochen und Zähnen vor (Giachelli und Steitz 2000). Außer in stark mineralisiertem Gewebe wurde Osteopontin aber auch in anderen Geweben, wie beispielsweise im Tumorgewebe, den Nieren, im duktalen Gewebe und in arteriellen Muskelzellen nachgewiesen, was darauf schließen lässt, dass Osteopontin noch andere wichtige Funktionen erfüllt (Denhardt und Guo 1993). Seit längerem ist auch bekannt, dass Osteopontin an der Regulierung zweier wichtiger Signalwege, die maßgeblich sind für Zellproliferation, -wachstum und -motilität, beteiligt ist. Hierbei handelt es sich um die Aktivierung von Akt, welches den Akt/mTOR- und den MAPK/ERK 1/2-Signalweg einleitet. Diese beiden Signalwege sind in der Lage, den programmierten Zelltod, die Apoptose zu verhindern (Robertson et al. 2010). Als Aktivator dieser beiden Signalwege nimmt Osteopontin also eine zentrale Rolle in 
Zellen ein, die eine starke Zellproliferation aufweisen. Schnelles Zellwachstum und intensive Proliferation lässt sich z.B im embryonalen Gewebe, aber auch in Gewebe welches fähig ist zur Regeneration nachweisen. Da Wurzelzement zeitlebens nachgebildet wird und nicht nur zur Regeneration fähig ist, sondern viel mehr sogar eine zentrale Rolle bei der Geweberegeneration im Verbund des Zahnhalteapparates nach einer parodontalen Erkrankung spielt, erklärt sich der Nachweis von Osteopontin in Zementoblasten. Zum ersten Mal gelang in humanen Zementoblasten auch ein Nachweis von Osteopontin in der Immunfluoreszenz.

\section{Bone Sialoprotein}

BSP ist ein Protein der EZM, welches mit mineralisiertem Gewebe des Skelettes und des Zahndurchbruchs (Dentition) assoziiert wird (Chen et al. 1992). BSP ist eines der multifunktionalen Mitglieder der Small Integrin Binding Ligand N-linked Glycoprotein (SIBLING)-Familie, zu denen beispielsweise auch Osteopontin gehört (Fisher und Fedarko 2003; Qin et al. 2004). Während etliche Studien zu der Bedeutung von BSP im Knochen in vitro und in vivo und sowohl an Nagern als auch im humanen Knochen durchgeführt wurden (Malaval et al. 2008; Malaval et al. 2009a; Malaval et al. 2009b; Boudiffa et al. 2010; Monfoulet et al. 2010; Wade-Gueye et al. 2012; Bouleftour et al. 2014), sind Angaben in der Literatur über BSP in humanem Wurzelzement kaum zu finden. In einem Mausmodell konnte gezeigt werden, dass Wurzelzement von BSP -/- Mäusen starke, auf eine Entwicklungsstörung zurückzuführende Defekte aufwies. Als Folge davon entstand ein progressiver parodontaler Attachmentverlust, eine Disorganisation im PDL und ein fortschreitender Verlust des Alveolarknochens (Foster et al. 2013). Weitere mikroskopische Untersuchungen zeigten, dass die Ultrastruktur des Zementes in den Molaren von BSP -/- Mäusen vollständig fehlt und folglich ein direkter Übergang vom Dentin ins PDL zu sehen ist. Häufig war dadurch auch eine Abtrennung des PDL vom Zahn zu sehen (Foster et al. 2015). Das mRNA-Level für BSP lag knapp über dem doppelten Niveau im Vergleich zur Kontrolle, den Osteoblasten aus dem Alveolarkamm.

\section{Osteonektin}

Beim Forschungsstand bezüglich Osteonektin, ein weiteres wichtiges Protein der 
EZM, verhält es sich ähnlich wie mit BSP. In der Literatur lässt sich kaum etwas über Osteonektin in Zusammenhang mit Zement und vor allem mit humanem Zement finden. Die Regulation und die genaue Funktion von Osteonektin konnte noch nicht eindeutig geklärt werden (Ram et al. 2015). Osteonektin, welches auch als secreted protein acid and rich in cysteine (SPARK) bekannt ist, findet sich vor allem in Geweben, die eine hohe Umbaurate zeigen (Termine et al. 1981). Des Weiteren wurde Osteonektin aber auch in verletztem und erkrankten Gewebe nachgewiesen (Brekken und Sage 2000). Bekanntermaßen besitzt Osteonektin Auswirkungen auf die Kollagensynthese und beeinflusst die Anordnung von Kollagen Typ I (Sage und Bornstein 1991). Osteonektin bindet an eine Anzahl unterschiedlicher Komponenten der EZM wie Thrombospondin 1, Vitronektin, Kollagen Typ I, II, III und V, sowie Kollagen Typ IV, das überwiegende Kollagen der Basalmembran (Brekken und Sage 2000). Im Knochen besitzt Osteopontin die Fähigkeit an Hydroxylapatit und an Zellen zu binden und ist somit in der Lage Zell-Matrix-Interaktionen zu modulieren (Lane und Sage 1994). Neben seiner Rolle bei der Mineralisation hat Osteonektin Einfluss auf unterschiedliche Wachstumsfaktoren und fördert die Expression von Matrix-Metalloproteasen (MMP), die wichtige Funktionen bei der Wundheilung besitzen (Bradshaw und Sage 2001). Patienten, die unter Osteogenesis imperfecta leiden, produzieren im Vergleich zur gesunden Kontrollgruppe deutlich weniger Osteonektin. Es besteht deshalb die Annahme, dass ein bestimmter Osteonektin-Spiegel vorhanden sein muss, damit stabiler Knochen entstehen kann und Knochenumbauprozesse problemlos stattfinden können. Im durchgeführten Tierexperiment konnte gezeigt werden, dass bei Osteonektin-Knockout-Mäusen eine stark verminderte Anzahl an Osteoblasten und Osteoklasten vorhanden war. Durch den dadurch gehemmten Remodellierungsprozess des Knochens entstand bei den Versuchstieren eine Osteopenie (Delany et al. 2000). Wie bereits im Text erwähnt, gibt es zu Osteonektin in Verbindung zum Wurzelzement und den Auswirkungen auf die Zemententwicklung keinerlei weiterführende Studien. Zement unterliegt zwar keinem ständigen Umbauprozess wie der Knochen, zählt aber genauso wie Knochen zum mineralisierten Gewebe. Es kann deshalb durchaus angenommen werden, dass Osteonektin auch für den Mineralisationsprozess von Zement eine Rolle spielt. Osteonektin konnte im Verlauf dieser Arbeit mittels FACS-Analyse nachgewiesen werden. 


\subsection{Diskussion über den Nachweis von VEGF im Zement}

VEGF (vascular endothelial growth factor) ist ein starker angiogener Faktor, der ursprünglich als ein für Endothelzellen spezifisches Mitogen beschrieben wurde (Ferrara et al. 1992). VEGF wird von vielen unterschiedlichen Zelltypen wie beispielsweise Tumorzellen (Boocock et al. 1995; Itakura et al. 2000), Makrophagen (Sunderkötter et al. 1994), Thrombozyten (Verheul et al. 1997) und Keratinozyten (Frank et al. 1995) produziert. Die Leistungen von VEGF sind nicht nur auf das vaskuläre System beschränkt; VEGF spielt auch eine Rolle in physiologischen Vorgängen wie der Knochenbildung (Gerber et al. 1999), der Hämatopoese (Ferrara et al. 1996), der Wundheilung (Chintalgattu et al. 2003) und der Gewebeentwicklung (Reichardt und Tomaselli 1991). Als einer der wichtigsten Wachstumsfaktoren für die Regulierung der vaskulären Entwicklung und der postnatalen Angiogenese (Hoeben et al. 2004) spielt VEGF eine entscheidende Rolle beim Reparatur- und Heilungsprozess von Knochen, vor allem da Angiogenese und Osteogenese eng miteinander verknüpft sind (Zelzer et al. 2004). In der Literatur sind bis jetzt keine Daten über einen Nachweis des Wachstumsfaktors VEGF im Zusammenhang mit Zement vorhanden. Obwohl Zement ein avaskuläres Gewebe ist, konnte über die qRT-PCR VEGF im Zement erfolgreich nachgewiesen werden. Da Zement ein hohes Regenerationspotenzial besitzt und entscheidend an der parodontalen Wundheilung beteiligt ist (Bosshardt und Selvig 1997), ist der Nachweis von VEGF, trotz der Avaskularität des Zementes ein wichtiger und nachvollziehbarer Fund. Außerdem ist PDL, welches eng mit Zement verknüpft ist und für die Aufrechterhaltung der Zahnverankerung ebenso eine wichtige Rolle spielt wie das Zement, stark vaskularisiert.

\subsection{Diskussion über den Nachweis von RANK/RANKL, Skle- rostin und der Alkalischen Phosphatase}

RANK und RANKL, ein Rezeptor-Ligand-Paar der Tumornekrosefaktor Superfamilie, bekamen eine Schlüsselrolle in der Physiologie des Knochens. Sie sind entscheident für den Knochenmetabolismus und sind unentbehrlich für die Entwicklung und Proliferation von Osteoklasten (Dougall et al. 1999; Kong et al. 1999). Als An- 
tagonist von RANKL dient Osteoprotegrin (OPG) und hemmt die Osteoklastendifferenzierung (Hofbauer et al. 2000). Obwohl der Ligand RANKL von Zementoblasten produziert wird (Lossdörfer et al. 2002b), ist seine Funktion in Zementoblasten weitestgehen ungeklärt. Mittels qRT-PCR konnte RANKL sowohl in nicht-differenzierten Zementoblasten als auch in osteogen differenzierten Zementoblasten nicht nachgewiesen werden. Die zementoblastären Zellen zeigten keinerlei Signal für das Vorhandensein von RANKL. Weitere Untersuchungen auf diesem Gebiet wären anzustreben. Ebenso wie RANK/RANKL, spielt auch Sklerostin eine wichtige Rolle im Knochenmetabolismus. Sklerostin ist ein Glykoprotein und lässt sich im Knochen in Osteozyten nachweisen (van Bezooijen et al. 2004). Indem es in der Lage ist, die Wnt (Wingless)-Signalkaskade zu deaktivieren, wirkt es hemmend auf die Osteoblasten und wirkt sich sogar positiv auf deren Zelltod aus (Winkler et al. 2003). Ausser dass Sklerostin vereinzelt in einigen Zementozyten nachgewiesen werden konnte (van Bezooijen et al. 2009), finden sich im Bezug auf das Zement und die Zementoblasten nur wenige Informationen. Sklerostin konnte in undifferenzierten Zementoblasten mittels qRT-PCR nicht nachgewiesen werden. Beim Nachweis von Sklerostin in osteogen differenzierten Zementoblasten konnte zwar eine Expression gezeigt werden, allerdings war die statistische Auswertung nicht möglich, da die Kontrolle, in diesem Fall die Osteoblasten aus dem Alveolarkamm keinerlei Expression zeigten. Ein weiterer osteoblastärer Marker, der untersucht wurde, ist die ALP. ALP ist ein Glykoprotein und fungiert als ein extrazellulär gebundenes Ektoenzym. Im menschlichen Körper kodieren vier Gene für die Isoenzyme, d.h.: die intestinaleALP, die plazentale-ALP, Keimzellen-ALP und nicht-gewebespezifische-ALP (Millan 2006). ALP spaltet Phosphorsäuremonoester und erhöht somit die lokale Konzentration von Phosphationen. Im Paradontium spielt ALP ebenfalls eine Rolle, da es am Gewebeumsatz des PDL, des Alveolarknochens und des Wurzelzementes beteiligt ist und für die Aufrechterhaltung eines gesunden Gewebes von großer Bedeutung ist (Ishikawa und Cimasoni 1970; Nakamura und Slots 1983; Binder et al. 1987). Die knochenspezifische Isoform der ALP (bone specific alkaline phosphatase, BALP) findet sich auf der Oberfläche von Osteoblasten und ist an der Mineralisation der Knochen-Matrix mitbeteiligt (Swaminathan 2001). Deshalb wird die BALP auch als Marker für die Aktivität von Osteoblasten angesehen (Dresner-Pollak et al. 1996) und dient aufgrund ihres charakteristischen Expressionsmusters wäh- 
rend der osteoblastären Differenzierung als Parameter der Osteoblastendifferenzierung (Siggelkow et al. 2002; Siggelkow et al. 2004). Leider konnte ALP mittels qRTPCR im Verlauf dieser Arbeit nicht erfolgreich in Zementoblasten nachgewiesen werden. Auch der Nachweis von ALP in osteogen differenzierten Zementoblasten blieb ergebnislos. In wie weit die ALP deshalb auch als ein charakteristischer Marker für Zementoblasten betrachtet werden kann bleibt ungeklärt.

\subsection{Die Rolle von CP-23 als spezifischer Zementmarker}

Ein neues Zement-spezifisches Molukül, das CEMP1 (cementum protein 1), auch unter dem Namen CP-23 bekannt, konnte vor einigen Jahren erfolgreich isoliert und charakterisiert werden. Dieses Protein wird speziell von Zementoblasten, einigen Subpopulationen des PDL und von mesenchymalen Stammzellen, die paravaskulär im PDL lokalisiert sind, exprimiert (Arzate et al. 2002; Alvarez-Pérez et al. 2006). Obwohl die genaue physiologische Funktion von CP-23 noch nicht komplett verstanden ist, besteht die Frage, dass dieses Molekül eine überaus wichtige Rolle bei der Zementogenese einnimmt und den Mineralisationsprozess und die damit verbundene Kalzium-Ablagerung während der Hydroxylapatit-Formation induziert (Villarreal-Ramírez et al. 2009). CP-23 sorgt für die Expression von Zementmarkern und wird von einem Teil der PDL-Zellen exprimiert. Diese Tatsache ist ein Hinweis darauf, dass PDL-Zellen, die dieses Protein exprimieren, eine Quelle von Progenitorzellen für Zementoblasten sein könnten. Während CP-23 in Zement und PDL nachgewiesen werden konnte, gab es keinen Nachweis in Osteoblasten. CP-23 scheint desweiteren die Expression von BSP vermindernd zu regulieren. Wenn PDL-Zellen allerdings einer osteogenen Differenzierung unterzogen werden, wird ihre CP-23 Expression wiederum reduziert (Komaki et al. 2012). CP-23 stand als Zement-spezifischer Marker auch im Fokus dieser Arbeit. Auswertungen der qRTPCR haben gezeigt, dass CP-23 nicht nur in Zementoblasten exprimiert wurde, sondern auch in den Osteoblasten aus dem Alveolarkamm, die als Kontrolle eingesetzt wurden. Es stellt sich also die Frage, ob CP-23 tatsächlich ein nur für Zement und seine Progenitorzellen spezifisches Protein ist. Da sich die Wissenschaft darüber uneinig ist, ob Zementoblasten und Osteoblasten die gleichen Vorläufer haben und wie ähnlich bzw. sogar gleich sich die Zellen sind, zumindest in Betracht auf ihr Expressionsverhalten, könnte die Expression von CP-23-mRNA in Osteoblasten ein 
Hinweis auf eine ähnliche bis gleiche Abstammung sein. Nachdem die Zementoblasten einer osteogenen Differenzierung unterzogen wurden, fiel das CP-23 Expressionslevel stark ab. Dieses Ergebnis würde mit den Ergebnissen der Arbeit von Komaki et al. (2012) übereinstimmen. Jedoch darf nicht vergessen werden, dass die Zementoblasten nicht eindeutig auf ihre osteogene Differenzierung überprüft werden konnten. Ob eine solche Differenzierung tatsächlich stattgefunden hat, bleibt deshalb ungeklärt.

Im Jahr 2015 konnte eine Arbeitsgruppe das Protein CP-23 von einer anderen Seite belichten. CP-23 konnte in sämtlichen Krebszelllinien sowohl auf mRNA als auch auf Proteinlevel nachgewiesen werden. In dieser Studie wurde angenommen, dass CP-23, ähnlich zu einigen Wachstumsfaktoren als ein Onkogen betrachtet werden kann (Bermúdez et al. 2015). Der Fund von CP-23 in Krebszellen würde die Vermutung untermauern, dass das Protein nicht nur eigens für Zement spezifisch ist.

\subsection{Diskussion über die Bedeutung einer Eigenständigkeit der Zelllinie der Zementoblasten}

Zu Beginn der Arbeit stellte sich die Frage nach dem Unterschied von Zementoblasten zu Osteoblasten. Vor allem bei dem Protein CP-23 war die Erwartung nur eine bzw. zumindest eine sehr hohe Expression in Zementoblasten zu finden und keine Expression in Osteoblasten. In Betracht der Ergebnisse ist jedoch eine geringere Expression auf mRNA-Level bei den Zementoblasten nachgewiesen worden. Außerdem ist jedes für Knochen typische Protein wie BSP, Osteocalcin, Osteonektin und Osteopontin auch in Zementoblasten gefunden worden. Auch die beiden Transkriptionsfaktoren RUNX2 und SOX9 und die beiden Proteoglykane Dekorin und Versikan zeigten Expression. VEGF, welches normalerweise in vaskularisiertem Gewebe nachgewiesen wird, zeigte ebenfalls positive Reaktionen in Zementoblasten. Obwohl im Vergleich zu Osteoblasten immer ein Expressionsunterschied auf mRNA-Level gezeigt werden konnte, gelang es nicht einen Unterschied an der Proteinzusammensetzung zu zeigen. Ob aus diesen Ergebnissen die Schlussfolgerung gezogen werden kann, dass zwischen den beiden Zellarten kein Unterschied besteht, lässt sich im Umfang dieser Arbeit letztendlich nicht eindeutig klären. 


\subsection{Schlussfolgerung und Fazit}

Die in dieser Arbeit vorgestellten Ergebnisse über die Nachweise unterschiedlicher Proteine in zementoblastären Zellen in vitro bilden erst den Anfang für ein besseres Verständnis über das humane Zement. Aufgrund seiner Komplexität und dem immernoch herrschenden Datendefizit sollten sowohl Wurzelzement als auch Zementoblasten und Zementozyten im Fokus weiterer Untersuchungen stehen. Nur so können neu gewonnene Erkenntnisse zielgerecht in therapeutische Maßnahmen umgewandelt werden. Die hier aufgeführten Versuche wurden beispielsweise nur in 2D-Kultur durchgeführt. Viele Zellen zeigen jedoch ein erhöhtes Expressionslevel und eine erhöhte Proteinsyntheseaktivität in einer 3D-Kultur. Es wäre deshalb von großem Interesse Zementoblasten in eine 3D-Kultur zu überführen und sie dann auf Proteine der EZM zu untersuchen. Interessant wäre auch eine Charakterisierung humaner Zementozyten und ein Vergleich dieser mit den Zementoblasten. Weiterhin sollte die Bedeutung von CP-23 für das Wurzelzement und seine mögliche Auswirkung auf andere Matrix-Proteine geklärt werden. Es darf nicht vergessen werden, dass sich diese Arbeit mit einer ausgewählten Anzahl an Proteinen beschäftigt hat und es noch sehr viele weitere wichtige Proteine im humanen Wurzelzement gibt, die noch nicht nachgewiesen wurden. Die Etablierung einer humanen immortalisierten Zementoblasten-Zelllinie stellt somit erst den Anfang einer zukunftsorientierten Forschung im Rahmen der Zahnmedizin, aber auch der Geweberegeneration dar. Auch die Fragestellung nach einer Eigenständigkeit der Zementoblasten-Zelllinie muss weiterführender untersucht werden. 


\section{Zusammenfassung}

Wurzelzement stellt eine Grundvoraussetzung für eine intakte Verankerung des Zahnes in seinem knöchernen Fach, der Alveole, dar. Gesundes Zement und sein Reparaturvermögen sind außerdem unabdingbar für ein gesundes Parodontium und somit auch für die Gesamtheit der Zahngesundheit.

In der vorliegenden Arbeit wurden humane Zementoblasten aus extrahierten Zähnen zunächst gewonnen und anschließend kultiviert, immortalisiert und charakterisiert. Untersucht wurden die sowohl für Zement als auch für Knochen als typisch angenommenen Proteine wie beispielsweise Kollagen Typ I und III, Osteocalcin, Osteopontin, Bone Sialoprotein und Osteonektin. Die beiden Transkriptionsfaktoren RUNX2 und SOX9, über die im Zusammenhang mit Zement noch recht wenig bekannt ist, konnten ebenfalls nachgewiesen werden. Vor allem über SOX9, den für die chondrogene Zelllinie typischen Transkriptionsfaktor, findet sich in der Literatur noch kein Zusammenhang zum Zement. Zusätzlich wurde das Cementum-Protein 1, das auch als CP-23 bekannt ist und in der Literatur als typischer, spezifischer Marker für Zement gilt, auf mRNA-Level untersucht und mittels Immunfluoreszenz dargestellt. Auch für die beiden Proteoglykane Dekorin und Versikan zeigten Zementoblasten eine Expression auf mRNA-Level.

Des Weiteren wurden die humanen Zementoblasten einer osteogenen Differenzierung unterzogen und auf die Expression von CP-23, Osteocalcin, Sklerostin, RANKL und ALP untersucht. Die osteogen differenzierten Zellen zeigten nur Signale für CP-23 und Osteocalcin. Ob die osteogene Differenzierung eindeutig erfolgreich war, bleibt ungeklärt und stellt einen wichtigen Aspekt für weiterführende Forschung auf diesem Gebiet dar.

Im Rahmen dieser Arbeit konnte gezeigt werden, dass die meisten für Knochen und Osteoblasten typischen Proteine auch in Zementoblasten nachgewiesen werden können. Inwiefern hieraus Schlüsse über die Ähnlichkeit von Zementoblasten und Osteoblasten gezogen werden können, bleibt eine zukünftige Forschungsaufgabe in der Zahnmedizin. 


\section{$6 \quad$ Anhang}

\subsection{Tabellenverzeichnis}

Tab. 1: Primermix .28

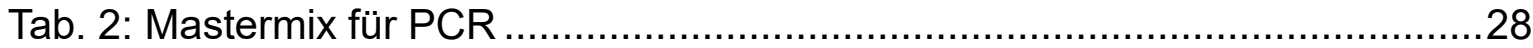

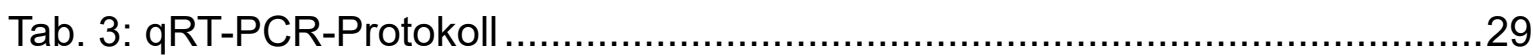

Tab. 4: Pipettierschema für Gradienten-PCR ............................................ 29

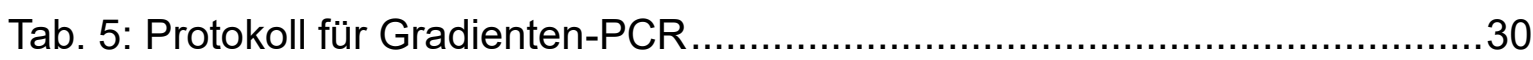

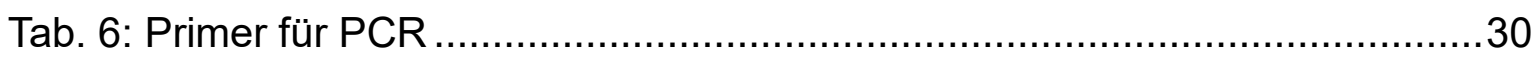

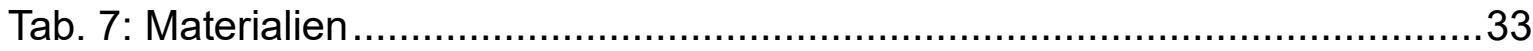

Tab. 8: Immunzytochemie: Primäre Antikörper ................................................ 34

Tab. 9: Immunzytochemie: Sekundäre Antikörper ..............................................34

Tab. 10: Western Blot: Zusammensetzung Trenngel.................................... 37

Tab. 11: Western Blot: Zusammensetzung Sammelgel ................................... 37

Tab. 12: Western Blot: primäre Antikörper..............................................41

Tab. 13: Western Blot: sekundäre Antikörper ...........................................41

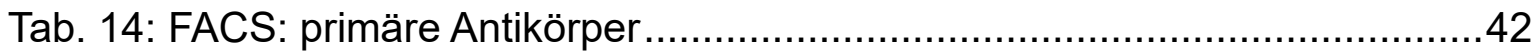

Tab. 15: FACS: sekundäre Antikörper ......................................................... 43

\subsection{Abbildungsverzeichnis}

Abb. 1: Lichtmikroskopische Darstellung von primären Zementoblasten ..............44

Abb. 2: Nachweis über Immortalisierung der Zementoblasten im Agarosegel ...... 45

Abb. 3: Übersicht- und Detailaufnahme von Zementoblasten ............................46

Abb. 4: Übersicht- und Detailaufnahme differenzierter Zementoblasten ...............47

Abb. 5: Relatives mRNA-Level undifferenzierter Zementoblasten von Proteinen der extrazellulären Matrix

Abb. 6: Relatives mRNA-Level undifferenzierter Zementoblasten von Proteinen der extrazellulären Matrix

Abb. 7: Relatives mRNA-Level osteogen differenzierter Zementoblasten von Osteocalcin und CP-23. 
Abb. 8: Nachweis von Kollagen Typ I auf Proteinebene.................................... 53

Abb. 9: Nachweis von RUNX2 auf Proteinebene .............................................. 54

Abb. 10: Nachweis von SOX9 auf Proteinebene .............................................. 55

Abb. 11: Immunzytochemische Darstellung von CP-23 ............................... 57

Abb. 12: Immunzytochemische Darstellung von Kollagen Typ III ........................57

Abb. 13: Immunzytochemischer Nachweis von Kollagen Typ I, Dekorin und

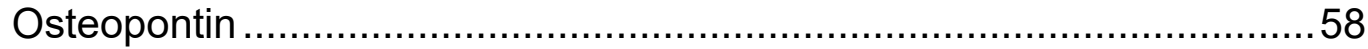

Abb. 14: Immunzytochemischer Nachweis von RUNX2 …................................. 59

Abb. 15: Immunzytochemischer Nachweis von SOX9 ..................................60

Abb. 16: FACS-Analyse intrazellulärer Proteine ...........................................61 


\section{$7 \quad$ Literaturverzeichnis}

Ababneh KT, Hall RC, Embery G (1998): Immunolocalization of glycosaminoglycans in ageing, healthy and periodontally diseased human cementum. Arch Oral Biol $\underline{43}$, 235-246

Ababneh KT, Hall RC, Embery G (1999): The proteoglycans of human cementum: immunohistochemical localization in healthy, periodontally involved and ageing teeth. J Periodontal Res $\underline{34}$, 87-96

Aberg T, Wozney J, Thesleff I (1997): Expression patterns of bone morphogenetic proteins (Bmps) in the developing mouse tooth suggest roles in morphogenesis and cell differentiation. Dev Dyn 210, 383-396

Aberg T, Cavender A, Gaikwad JS, Bronckers ALJJ, Wang X, Waltimo-Sirén J, Thesleff I, D'Souza RN (2004): Phenotypic changes in dentition of Runx2 homozygotenull mutant mice. J Histochem Cytochem $\underline{52}, 131-139$

Akiyama H, Chaboissier M-C, Martin JF, Schedl A, de Crombrugghe B (2002): The transcription factor Sox9 has essential roles in successive steps of the chondrocyte differentiation pathway and is required for expression of Sox5 and Sox6. Genes Dev $\underline{16}, 2813-2828$

Akiyama H, Kim J-E, Nakashima K, Balmes G, Iwai N, Deng JM, Zhang Z, Martin JF, Behringer RR, Nakamura T, de Crombrugghe B (2005): Osteo-chondroprogenitor cells are derived from Sox9 expressing precursors. Proc Natl Acad Sci U S A 102, 14665-14670

Alvarez Pérez MA, Pitaru S, Alvarez Fregoso O, Reyes Gasga J, Arzate H (2003): Anti-cementoblastoma-derived protein antibody partially inhibits mineralization on a cementoblastic cell line. J Struct Biol $\underline{143}, 1-13$

Alvarez-Pérez MA, Narayanan S, Zeichner-David M, Rodríguez Carmona B, Arzate $H$ (2006): Molecular cloning, expression and immunolocalization of a novel human cementum-derived protein (CP-23). Bone $\underline{38}, 409-419$

Amstad-Jossi M, Oksche A: The periodontium. Springer, Berlin [u.a.] 1986 
Arzate H, Olson SW, Page RC, Narayanan AS (1992a): Isolation of human tumor cells that produce cementum proteins in culture. Bone Miner $\underline{18}, 15-30$

Arzate H, Olson SW, Page RC, Gown AM, Narayanan AS (1992b): Production of a monoclonal antibody to an attachment protein derived from human cementum. FASEB $\underline{6}, 2990-2995$

Arzate H, Chimal-Monroy J, Hernández-Lagunas L, Díaz de León L (1996): Human cementum protein extract promotes chondrogenesis and mineralization in mesenchymal cells. J Periodontal Res $\underline{31}, 144-148$

Arzate H, Alvarez-Pérez MA, Aguilar-Mendoza ME, Alvarez-Fregoso O (1998): Human cementum tumor cells have different features from human osteoblastic cells in vitro. J Periodontal Res $\underline{33}$, 249-258

Arzate $\mathrm{H}$, Jiménez-García LF, Alvarez-Pérez MA, Landa A, Bar-Kana I, Pitaru S (2002): Immunolocalization of a human cementoblastoma-conditioned medium-derived protein. J Dent Res $\underline{81}, 541-546$

Arzate H, Zeichner-David M, Mercado-Celis G (2015): Cementum proteins: role in cementogenesis, biomineralization, periodontium formation and regeneration. Periodontol $2000 \underline{67}, 211-233$

Ayasaka N, Kondo T, Goto T, Kido MA, Nagata E, Tanaka T (1992): Differences in the transport systems between cementocytes and osteocytes in rats using microperoxidase as a tracer. Arch Oral Biol 37, 363-369

Azaz B, Ulmansky M, Moshev R, Sela J (1974): Correlation between age and thickness of cementum in impacted teeth. Oral Surg Oral Med Oral Pathol $\underline{38}, 691-694$

Bartold PM, Miki Y, McAllister B, Narayanan AS, Page RC (1988): Glycosaminoglycans of human cementum. J Periodontal Res $\underline{23}, 13-17$

Bartold PM, Walsh LJ, Narayanan AS (2000): Molecular and cell biology of the gingiva. Periodontol $2000 \underline{24}, 28-55$

Beck F, Tucci J, Russell A, Senior PV, Ferguson MW (1995): The expression of the gene coding for parathyroid hormone-related protein (PTHrP) during tooth development in the rat. Cell Tissue Res $\underline{280}, 283-290$ 
Becker J, Schuppan D, Rabanus JP, Rauch R, Niechoy U, Gelderblom HR (1991): Immunoelectron microscopic localization of collagens type I, V, VI and of procollagen type III in human periodontal ligament and cementum. J Histochem Cytochem $\underline{39}, 103-110$

Beertsen W, Van den Bos T, Everts V (1990): The possible role of alkaline phosphatase in acellular cementum formation. J Biol Buccale 18, 203-205

Beertsen W, McCulloch CA, Sodek J (1997): The periodontal ligament: a unique, multifunctional connective tissue. Periodontol 2000 13, 20-40

Beertsen W, VandenBos T, Everts V (1999): Root development in mice lacking functional tissue non-specific alkaline phosphatase gene: inhibition of acellular cementum formation. J Dent Res $\underline{78}, 1221-1229$

Berkovitz BKB, Holland GR, Moxham BJ: Oral Anatomy, Histology and Embryology. 4. Auflage; Mosby/Elsevier, Edinburgh [u. a.] 2009

Bermúdez M, Imaz-Rosshandler I, Rangel-Escareño C, Zeichner-David M, Arzate H, Mercado-Celis GE (2015): CEMP1 Induces Transformation in Human Gingival Fibroblasts. PloS One 10, e0127286

Berry JE, Zhao M, Jin Q, Foster BL, Viswanathan H, Somerman MJ (2003): Exploring the origins of cementoblasts and their trigger factors. Connect Tissue Res $\underline{44}$ Suppl 1, 97-102

Bevelander G, Nakahara H (1968): The fine structure of the human peridental ligament. Anat Rec 162, 313-325

Bi W, Deng JM, Zhang Z, Behringer RR, de Crombrugghe B (1999): Sox9 is required for cartilage formation. Nat Genet 22, 85-89

Bianco P, Fisher LW, Young MF, Termine JD, Robey PG (1990): Expression and localization of the two small proteoglycans biglycan and decorin in developing human skeletal and non-skeletal tissues. J Histochem Cytochem $\underline{38}, 1549-1563$

Binder TA, Goodson JM, Socransky SS (1987): Gingival fluid levels of acid and alkaline phosphatase. J Periodontal Res $\underline{22}, 14-19$ 
Birkedal-Hansen H, Butler WT, Taylor RE (1977): Proteins of the periodontium. Characterization of the insoluble collagens of bovine dental cementum. Calcif Tissue Res $\underline{23}$, 39-44

Boocock CA, Charnock-Jones DS, Sharkey AM, McLaren J, Barker PJ, Wright KA, Twentyman PR, Smith SK (1995): Expression of vascular endothelial growth factor and its receptors flt and KDR in ovarian carcinoma. J Natl Cancer Inst $\underline{87}, 506-516$

Bosshardt D, Schroeder HE (1990): Evidence for rapid multipolar and slow unipolar production of human cellular and acellular cementum matrix with intrinsic fibers. $J$ Clin Periodontol 17, 663-668

Bosshardt DD (2005): Are cementoblasts a subpopulation of osteoblasts or a unique phenotype? J Dent Res 84, 390-406

Bosshardt DD, Schroeder HE (1991a): Initiation of acellular extrinsic fiber cementum on human teeth. A light- and electron-microscopic study. Cell Tissue Res $\underline{263}$, $311-324$

Bosshardt DD, Schroeder HE (1991b): Establishment of acellular extrinsic fiber cementum on human teeth. A light- and electron-microscopic study. Cell Tissue Res $\underline{263}, 325-336$

Bosshardt DD, Schroeder HE (1992): Initial formation of cellular intrinsic fiber cementum in developing human teeth. A light- and electron-microscopic study. Cell Tissue Res 267, 321-335

Bosshardt DD, Schroeder HE (1994): How repair cementum becomes attached to the resorbed roots of human permanent teeth. Acta Anat (Basel) 150, 253-266

Bosshardt DD, Selvig KA (1997): Dental cementum: the dynamic tissue covering of the root. Periodontol $2000 \underline{13}, 41-75$

Bosshardt DD, Sculean A (2009): Does periodontal tissue regeneration really work? Periodontol 2000 51, 208-219

Bosshardt DD, Zalzal S, McKee MD, Nanci A (1998): Developmental appearance and distribution of bone sialoprotein and osteopontin in human and rat cementum. Anat Rec 250, 13-33 
Bosshardt DD, Sculean A, Donos N, Lang NP (2006): Pattern of mineralization after regenerative periodontal therapy with enamel matrix proteins. Eur J Oral Sci $\underline{114}$ Suppl 1, 225-231

Boudiffa M, Wade-Gueye NM, Guignandon A, Vanden-Bossche A, Sabido O, Aubin JE, Jurdic P, Vico L, Lafage-Proust MH, Malaval L (2010): Bone sialoprotein deficiency impairs osteoclastogenesis and mineral resorption in vitro. J Bone Miner Res $\underline{25}, 2669-2679$

Bouleftour W, Boudiffa M, Wade-Gueye NM, Bouët G, Cardelli M, Laroche N, Vanden-Bossche A, Thomas M, Bonnelye E, Aubin JE, et al. (2014): Skeletal development of mice lacking bone sialoprotein (BSP)--impairment of long bone growth and progressive establishment of high trabecular bone mass. PloS One $\underline{9}$, e95144

Bradshaw AD, Sage EH (2001): SPARC, a matricellular protein that functions in cellular differentiation and tissue response to injury. J Clin Invest 107, 1049-1054

Brekken RA, Sage EH (2000): SPARC, a matricellular protein: at the crossroads of cell-matrix. Matrix Biol J Int Soc Matrix Biol 19, 569-580

Bronckers AL, Farach-Carson MC, Van Waveren E, Butler WT (1994): Immunolocalization of osteopontin, osteocalcin, and dentin sialoprotein during dental root formation and early cementogenesis in the rat. J Bone Miner Res $\underline{9}, 833-841$

Bronckers AL, Engelse MA, Cavender A, Gaikwad J, D'Souza RN (2001): Cell-specific patterns of Cbfa1 mRNA and protein expression in postnatal murine dental tissues. Mech Dev 101, 255-258

Butler WT, Brunn JC, Qin C (2003): Dentin extracellular matrix (ECM) proteins: comparison to bone ECM and contribution to dynamics of dentinogenesis. Connect Tissue Res 44 Suppl $1,171-178$

Camilleri S, McDonald F (2006): Runx2 and dental development. Eur J Oral Sci 114, 361-373

Cao Z, Zhang H, Zhou X, Han X, Ren Y, Gao T, Xiao Y, de Crombrugghe B, Somerman MJ, Feng JQ (2012): Genetic evidence for the vital function of Osterix in cementogenesis. J Bone Miner Res 27, 1080-1092 
Carmona-Rodríguez B, Alvarez-Pérez MA, Narayanan AS, Zeichner-David M, Reyes-Gasga J, Molina-Guarneros J, García-Hernández AL, Suárez-Franco JL, Chavarría IG, Villarreal-Ramírez E, Arzate H (2007): Human Cementum Protein 1 induces expression of bone and cementum proteins by human gingival fibroblasts. Biochem Biophys Res Commun $\underline{358}$, 763-769

Chen F-M, Zhang J, Zhang M, An Y, Chen F, Wu Z-F (2010): A review on endogenous regenerative technology in periodontal regenerative medicine. Biomaterials 31, 7892-7927

Chen J, Shapiro HS, Sodek J (1992): Development expression of bone sialoprotein mRNA in rat mineralized connective tissues. J Bone Miner Res $\underline{7}$, 987-997

Chen J, McCulloch CA, Sodek J (1993): Bone sialoprotein in developing porcine dental tissues: cellular expression and comparison of tissue localization with osteopontin and osteonectin. Arch Oral Biol $\underline{38}, 241-249$

Chen S, Gu TT, Sreenath T, Kulkarni AB, Karsenty G, MacDougall M (2002): Spatial expression of Cbfa1/Runx2 isoforms in teeth and characterization of binding sites in the DSPP gene. Connect Tissue Res $\underline{43}$, 338-344

Cheng H, Caterson B, Neame PJ, Lester GE, Yamauchi M (1996): Differential distribution of lumican and fibromodulin in tooth cementum. Connect Tissue Res $\underline{34}$, 87-96

Cheng H, Caterson B, Yamauchi M (1999): Identification and immunolocalization of chondroitin sulfate proteoglycans in tooth cementum. Connect Tissue Res $\underline{40}, 37-$ 47

Chintalgattu V, Nair DM, Katwa LC (2003): Cardiac myofibroblasts: a novel source of vascular endothelial growth factor (VEGF) and its receptors Flt-1 and KDR. J Mol Cell Cardiol 35, 277-286

Cho Ml, Garant PR (1988): Ultrastructural evidence of directed cell migration during initial cementoblast differentiation in root formation. J Periodontal Res $\underline{23}, 268-276$

Cho MI, Garant PR (2000): Development and general structure of the periodontium. Periodontol $2000 \underline{24}$, 9-27 
Christner P, Robinson P, Clark CC (1977): A preliminary characterization of human cementum collagen. Calcif Tissue Res $\underline{23}, 147-150$

Christoffersen J, Landis WJ (1991): A contribution with review to the description of mineralization of bone and other calcified tissues in vivo. Anat Rec $\underline{230}$, 435-450

Conrads G: Grundlagen, Klassifikation und Diagnostik. (Praxisorientiertes und praxiswirksames Expertenwissen für ZahnärzteSpitta-Fachinformationen). Spitta, Balingen 2010

Curatolo L, Erba E, Morasca L (1984): Culture conditions induce the appearance of immortalized C3H mouse cell lines. In Vitro $\underline{20}, 597-601$

Danielson KG, Baribault H, Holmes DF, Graham H, Kadler KE, lozzo RV (1997): Targeted disruption of decorin leads to abnormal collagen fibril morphology and skin fragility. J Cell Biol 136, 729-743

Davies JE (1996): In vitro modeling of the bone/implant interface. Anat Rec $\underline{245}$, 426-445

Delany AM, Amling M, Priemel M, Howe C, Baron R, Canalis E (2000): Osteopenia and decreased bone formation in osteonectin-deficient mice. J Clin Invest $\underline{105}, 1325$

Denhardt DT, Guo X (1993): Osteopontin: a protein with diverse functions. FASEB J $\underline{7}, 1475-1482$

Denhardt DT, Lopez CA, Rollo EE, Hwang SM, An XR, Walther SE (1995): Osteopontin-induced modifications of cellular functions. Ann N Y Acad Sci $\underline{760}, 127-142$

Denton GB: The discovery of cementum: Northwestern University, Chicago 1941

D’Errico JA, MacNeil RL, Takata T, Berry J, Strayhorn C, Somerman MJ (1997): Expression of bone associated markers by tooth root lining cells, in situ and in vitro. Bone 20, 117-126

D'Errico JA, Ouyang H, Berry JE, MacNeil RL, Strayhorn C, Imperiale MJ, Harris NL, Goldberg H, Somerman MJ (1999): Immortalized cementoblasts and periodontal ligament cells in culture. Bone $\underline{25}, 39-47$ 
Diekwisch TG (2001): The developmental biology of cementum. Int J Dev Biol $\underline{45}$, 695-706

Diekwisch TGH (2002): Pathways and fate of migratory cells during late tooth organogenesis. Connect Tissue Res $\underline{43}$, 245-256

Diep L, Matalova E, Mitsiadis TA, Tucker AS (2009): Contribution of the tooth bud mesenchyme to alveolar bone. J Exp Zoolog B Mol Dev Evol 312B, 510-517

Dougall WC, Glaccum M, Charrier K, Rohrbach K, Brasel K, De Smedt T, Daro E, Smith J, Tometsko ME, Maliszewski CR, et al. (1999): RANK is essential for osteoclast and lymph node development. Genes Dev $\underline{13}, 2412-2424$

Dresner-Pollak R, Parker RA, Poku M, Thompson J, Seibel MJ, Greenspan SL (1996): Biochemical markers of bone turnover reflect femoral bone loss in elderly women. Calcif Tissue Int $\underline{59}, 328-333$

D'Souza RN, Aberg T, Gaikwad J, Cavender A, Owen M, Karsenty G, Thesleff I (1999): Cbfa1 is required for epithelial-mesenchymal interactions regulating tooth development in mice. Dev Camb Engl 126, 2911-2920

Ducy P (2000): Cbfa1: a molecular switch in osteoblast biology. Dev Dyn 219, $461-$ 471

Ducy P, Zhang R, Geoffroy V, Ridall AL, Karsenty G (1997): Osf2/Cbfa1: a transcriptional activator of osteoblast differentiation. Cell $\underline{89}, 747-754$

Ducy P, Starbuck M, Priemel M, Shen J, Pinero G, Geoffroy V, Amling M, Karsenty G (1999): A Cbfa1-dependent genetic pathway controls bone formation beyond embryonic development. Genes Dev 13, 1025-1036

el Mostehy MR, Stallard RE (1968): Intermediate cementum. J Periodontal Res $\underline{3}$, 24-29

Embery G, Hall R, Waddington R, Septier D, Goldberg M (2001): Proteoglycans in dentinogenesis. Crit Rev Oral Biol Med 12, 331-349 
Engel J, Taylor W, Paulsson M, Sage H, Hogan B (1987): Calcium binding domains and calcium-induced conformational transition of SPARC/BM-40/osteonectin, an extracellular glycoprotein expressed in mineralized and nonmineralized tissues. Biochemistry (Mosc) 트, 6958-6965

Ferrara N, Houck K, Jakeman L, Leung DW (1992): Molecular and biological properties of the vascular endothelial growth factor family of proteins. Endocr Rev $\underline{13}$, $18-32$

Ferrara N, Carver-Moore K, Chen H, Dowd M, Lu L, O'Shea KS, Powell-Braxton L, Hillan KJ, Moore MW (1996): Heterozygous embryonic lethality induced by targeted inactivation of the VEGF gene. Nature $\underline{380}$, 439-442

Fisher LW, Termine JD (1985): Noncollagenous proteins influencing the local mechanisms of calcification. Clin Orthop 362-385

Fisher LW, Fedarko NS (2003): Six genes expressed in bones and teeth encode the current members of the SIBLING family of proteins. Connect Tissue Res 44 Suppl $1,33-40$

Fong CD, Hammarström L (2000): Expression of amelin and amelogenin in epithelial root sheath remnants of fully formed rat molars. Oral Surg Oral Med Oral Pathol Oral Radiol Endod 90, 218-223

Fong CD, Slaby I, Hammarström L (1996): Amelin: an enamel-related protein, transcribed in the cells of epithelial root sheath. J Bone Miner Res 11, 892-898

Foster BL, Soenjaya Y, Nociti FH, Holm E, Zerfas PM, Wimer HF, Holdsworth DW, Aubin JE, Hunter GK, Goldberg HA, Somerman MJ (2013): Deficiency in acellular cementum and periodontal attachment in bsp null mice. J Dent Res $\underline{92}, 166-172$

Foster BL, Ao M, Willoughby C, Soenjaya Y, Holm E, Lukashova L, Tran AB, Wimer HF, Zerfas PM, Nociti FH, et al. (2015): Mineralization defects in cementum and craniofacial bone from loss of bone sialoprotein. Bone $\underline{78}, 150-164$

Franceschi RT (1999): The developmental control of osteoblast-specific gene expression: role of specific transcription factors and the extracellular matrix environment. Crit Rev Oral Biol Med 10, 40-57 
Frank S, Hübner G, Breier G, Longaker MT, Greenhalgh DG, Werner S (1995): Regulation of vascular endothelial growth factor expression in cultured keratinocytes. Implications for normal and impaired wound healing. J Biol Chem 270, 1260712613

Franz-Odendaal TA, Hall BK, Witten PE (2006): Buried alive: how osteoblasts become osteocytes. Dev Dyn 235, 176-190

Furseth R (1967): A microradiographic and electron microscopic study of the cementum of human deciduous teeth. Acta Odontol Scand 25, 613-645

Furseth R (1969): The fine structure of the cellular cementum of young human teeth. Arch Oral Biol 14, 1147-1158

Furseth R (1974): The fine structure of acellular cementum in young human premolars. Scand J Dent Res $\underline{82}, 437-441$

Furseth R, Johansen E (1968): A microradiographic comparison of sound and carious human dental cementum. Arch Oral Biol 13, 1197-1206

Garant PR: Oral cells and tissues. Quintessence Pub. Co, Chicago 2003

Geoffroy V, Corral DA, Zhou L, Lee B, Karsenty G (1998): Genomic organization, expression of the human CBFA1 gene, and evidence for an alternative splicing event affecting protein function. Mamm Genome $\underline{9}, 54-57$

Gerber HP, Vu TH, Ryan AM, Kowalski J, Werb Z, Ferrara N (1999): VEGF couples hypertrophic cartilage remodeling, ossification and angiogenesis during endochondral bone formation. Nat Med $\underline{5}, 623-628$

Giachelli CM, Steitz S (2000): Osteopontin: a versatile regulator of inflammation and biomineralization. Matrix Biol $\underline{19}, 615-622$

Gibson WA, Fullmer HM (1967): Histochemistry of the periodontal ligament. II. The phosphatases. Periodontics $\underline{5}, 226-232$ 
Grcević D, Katavić V, Lukić IK, Kovacić N, Lorenzo JA, Marusić A (2001): Cellular and molecular interactions between immune system and bone. Croat Med $\mathrm{J} \underline{42}$, 384-392

Grzesik WJ, Narayanan AS (2002): Cementum and periodontal wound healing and regeneration. Crit Rev Oral Biol Med $\underline{13}, 474-484$

Grzesik WJ, Kuzentsov SA, Uzawa K, Mankani M, Robey PG, Yamauchi M (1998): Normal human cementum-derived cells: isolation, clonal expansion, and in vitro and in vivo characterization. J Bone Miner Res $\underline{13}$, 1547-1554

Grzesik WJ, Cheng H, Oh JS, Kuznetsov SA, Mankani MH, Uzawa K, Robey PG, Yamauchi M (2000): Cementum-forming cells are phenotypically distinct from boneforming cells. J Bone Miner Res $\underline{15}, 52-59$

Gubbay J, Collignon J, Koopman P, Capel B, Economou A, Münsterberg A, Vivian N, Goodfellow P, Lovell-Badge R (1990): A gene mapping to the sex-determining region of the mouse $\mathrm{Y}$ chromosome is a member of a novel family of embryonically expressed genes. Nature $\underline{346}, 245-250$

Häkkinen L, Oksala O, Salo T, Rahemtulla F, Larjava H (1993): Immunohistochemical localization of proteoglycans in human periodontium. J Histochem Cytochem $\underline{41}, 1689-1699$

Hammarström L, Alatli I, Fong CD (1996): Origins of cementum. Oral Dis $\underline{2}$, 63-69

Harlamb SC, Messer HH (1996): The identification of proteoglycan-associated mRNAs in human dental pulp cells. Arch Oral Biol $\underline{41}, 1097-1100$

Hasegawa T, Yoshimura Y, Kikuiri T, Yawaka Y, Takeyama S, Matsumoto A, Oguchi $\mathrm{H}$, Shirakawa $\mathrm{T}$ (2002): Expression of receptor activator of NF-kappa B ligand and osteoprotegerin in culture of human periodontal ligament cells. J Periodontal Res $\underline{37}, 405-411$

Hassell TM (1993): Tissues and cells of the periodontium. Periodontol $2000 \underline{3}, 9-38$

Hauschka PV, Carr SA (1982): Calcium-dependent alpha-helical structure in osteocalcin. Biochemistry (Mosc) $\underline{21}, 2538-2547$ 
Hauschka PV, Wians FH (1989): Osteocalcin-hydroxyapatite interaction in the extracellular organic matrix of bone. Anat $\operatorname{Rec} \underline{224}, 180-188$

Hauschka PV, Lian JB, Cole DE, Gundberg CM (1989): Osteocalcin and matrix Gla protein: vitamin K-dependent proteins in bone. Physiol Rev $\underline{69}$, 990-1047

Hay ED: Collagen and Other Matrix Glycoproteins in Embryogenesis. In: Hay ED (Hrsg.): Cell Biology of Extracellular Matrix. Plenum Press, New York 1991, 419-462

Hellwig E, Klimek J, Attin T: Einführung in die Zahnerhaltung: Prüfungswissen Kariologie, Endodontologie und Parodontologie ; mit 60 Tabellen. 5., überarb. und erw. Auflage, Dt. Zahnärzte-Verlag, Köln 2010

Hirata A, Sugahara T, Nakamura H (2009): Localization of runx2, osterix, and osteopontin in tooth root formation in rat molars. J Histochem Cytochem $\underline{57}$, 397-403

Hitchin AD (1975): Cementum and other root abnormalities of permanent teeth in cleidocranial dysostosis. Br Dent J $\underline{139}$, 313-318

Hoeben A, Landuyt B, Highley MS, Wildiers H, Van Oosterom AT, De Bruijn EA (2004): Vascular endothelial growth factor and angiogenesis. Pharmacol Rev $\underline{56}$, $549-580$

Hofbauer LC, Heufelder AE (2001): Role of receptor activator of nuclear factor-kappaB ligand and osteoprotegerin in bone cell biology. J Mol Med Berl Ger $\underline{79}$, 243253

Hofbauer LC, Khosla S, Dunstan CR, Lacey DL, Boyle WJ, Riggs BL (2000): The roles of osteoprotegerin and osteoprotegerin ligand in the paracrine regulation of bone resorption. J Bone Miner Res $\underline{15}, 2-12$

Huang W, Chung UI, Kronenberg HM, de Crombrugghe B (2001): The chondrogenic transcription factor Sox9 is a target of signaling by the parathyroid hormone-related peptide in the growth plate of endochondral bones. Proc Natl Acad Sci $\underline{98}, 160-165$

Hui M, Tenenbaum HC (1998): New face of an old enzyme: alkaline phosphatase may contribute to human tissue aging by inducing tissue hardening and calcification. Anat Rec 253, 91-94 
lozzo RV, Murdoch AD (1996): Proteoglycans of the extracellular environment: clues from the gene and protein side offer novel perspectives in molecular diversity and function. FASEB $\underline{10}, 598-614$

Ishikawa I, Cimasoni G (1970): Alkaline phosphatase in human gingival fluid and its relation to periodontitis. Arch Oral Biol $\underline{15}, 1401-1404$

Itakura J, Ishiwata T, Shen B, Kornmann M, Korc M (2000): Concomitant over-expression of vascular endothelial growth factor and its receptors in pancreatic cancer.

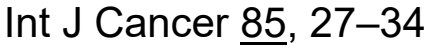

Ito $Y$ (1999): Molecular basis of tissue-specific gene expression mediated by the runt domain transcription factor PEBP2/CBF. Genes Cells Devoted Mol Cell Mech 4, 685-696

Jäger A, Götz W, Lossdörfer S, Rath-Deschner B (2010): Localization of SOST/sclerostin in cementocytes in vivo and in mineralizing periodontal ligament cells in vitro. J Periodontal Res $\underline{45}$, 246-254

Janones DS, Massa LF, Arana-Chavez VE (2005): Immunocytochemical examination of the presence of amelogenin during the root development of rat molars. Arch Oral Biol $\underline{50}, 527-532$

Jensen BL, Kreiborg S (1990): Development of the dentition in cleidocranial dysplasia. J Oral Pathol Med 19, 89-93

Kagayama M, Li HC, Zhu J, Sasano Y, Hatakeyama Y, Mizoguchi I (1997): Expression of osteocalcin in cementoblasts forming acellular cementum. J Periodontal Res $\underline{32}, 273-278$

Karring T, Nyman S, Gottlow J, Laurell L (1993): Development of the biological concept of guided tissue regeneration--animal and human studies. Periodontol 2000 , 26-35

Karsenty G (2000): The central regulation of bone remodeling. Trends Endocrinol Metab TEM 11, 437-439

Karsenty G, Oury F (2012): Biology without walls: the novel endocrinology of bone. Annu Rev Physiol $\underline{74}$, 87-105 
Karsenty G, Ferron M (2012): The contribution of bone to whole-organism physiology. Nature $\underline{481}, 314-320$

Keene DR, Sakai LY, Bächinger HP, Burgeson RE (1987): Type III collagen can be present on banded collagen fibrils regardless of fibril diameter. J Cell Biol $\underline{105}$, 2393-2402

Kiefer JC (2007): Back to basics: Sox genes. Dev Dyn 236, 2356-2366

King GN, Cochran DL (2002): Factors that modulate the effects of bone morphogenetic protein-induced periodontal regeneration: a critical review. J Periodontol $\underline{73}$, 925-936

Kitagawa M, Tahara H, Kitagawa S, Oka H, Kudo Y, Sato S, Ogawa I, Miyaichi M, Takata T (2006): Characterization of established cementoblast-like cell lines from human cementum-lining cells in vitro and in vivo. Bone $\underline{39}, 1035-1042$

Knox B, Aukhil I (1988): Ultrastructural study of experimental cementum regeneration in rats. J Periodontal Res $\underline{23}, 60-67$

Kobayashi I, Kiyoshima T, Wada H, Matsuo K, Nonaka K, Honda J, Koyano K, Sakai $\mathrm{H}$ (2006): Type II/III Runx2/Cbfa1 is required for tooth germ development. Bone $\underline{38}$, 836-844

Komaki M, Iwasaki K, Arzate H, Narayanan AS, Izumi Y, Morita I (2012): Cementum protein 1 (CEMP1) induces a cementoblastic phenotype and reduces osteoblastic differentiation in periodontal ligament cells. J Cell Physiol 227, 649-657

Kong YY, Yoshida H, Sarosi I, Tan HL, Timms E, Capparelli C, Morony S, Oliveirados-Santos AJ, Van G, Itie A, et al. (1999): OPGL is a key regulator of osteoclastogenesis, lymphocyte development and lymph-node organogenesis. Nature $\underline{397}$, 315-323

Kuchler U, Schwarze UY, Dobsak T, Heimel P, Bosshardt DD, Kneissel M, Gruber R (2014): Dental and periodontal phenotype in sclerostin knockout mice. Int J Oral Sci 6, $70-76$

Kundu M, Javed A, Jeon J-P, Horner A, Shum L, Eckhaus M, Muenke M, Lian JB, Yang Y, Nuckolls GH, et al. (2002): Cbfbeta interacts with Runx2 and has a critical role in bone development. Nat Genet $\underline{32}, 639-644$ 
Lane TF, Sage EH (1994): The biology of SPARC, a protein that modulates cellmatrix interactions. FASEB $\underline{8}, 163-173$

Larjava H, Häkkinen L, Rahemtulla F (1992): A biochemical analysis of human periodontal tissue proteoglycans. Biochem J 284 ( Pt 1), 267-274

Lehnen SDM, Götz W, Baxmann M, Jäger A (2012): Immunohistochemical evidence for sclerostin during cementogenesis in mice. Ann Anat Anat Anz 194, 415-421

Lekic PC, Pender N, McCulloch CA (1997): Is fibroblast heterogeneity relevant to the health, diseases, and treatments of periodontal tissues? Crit Rev Oral Biol Med $\underline{8}, 253-268$

Lester KS (1969): The incorporation of epithelial cells by cementum. J Ultrastruct Res $\underline{27}, 63-87$

Levanon D, Negreanu V, Bernstein Y, Bar-Am I, Avivi L, Groner Y (1994): AML1, AML2, and AML3, the human members of the runt domain gene-family: CDNA structure, expression, and chromosomal localization. Genomics $\underline{23}$, 425-432

Lindskog S, Blomlöf $L$ (1983): Cementum hypoplasia in teeth affected by juvenile periodontitis. J Clin Periodontol 10, 443-451

Liu HW, Yacobi R, Savion N, Narayanan AS, Pitaru S (1997): A collagenous cementum-derived attachment protein is a marker for progenitors of the mineralized tissueforming cell lineage of the periodontal ligament. J Bone Miner Res 12, 1691-1699

Lossdörfer S, Götz W, Jäger A (2002a): Immunohistochemical localization of receptor activator of nuclear factor kappaB (RANK) and its ligand (RANKL) in human deciduous teeth. Calcif Tissue Int 71, 45-52

Lossdörfer S, Götz W, Jäger A (2002b): Immunohistochemical localization of receptor activator of nuclear factor kappaB (RANK) and its ligand (RANKL) in human deciduous teeth. Calcif Tissue Int $\underline{71}, 45-52$

Lukinmaa PL, Waltimo J (1992): Immunohistochemical localization of types I, V, and $\mathrm{VI}$ collagen in human permanent teeth and periodontal ligament. J Dent Res $\underline{71}$, 391-397 
Luo W, Slavkin HC, Snead ML (1991): Cells from Hertwig's epithelial root sheath do not transcribe amelogenin. J Periodontal Res $\underline{26}, 42-47$

Macieira-Coelho A (1980): Implications of the reorganization of the cell genome for aging or immortalization of dividing cells in vitro. Gerontology $\underline{26}, 276-282$

MacNeil RL, Somerman MJ (1993): Molecular factors regulating development and regeneration of cementum. J Periodontal Res $\underline{28}, 550-559$

Macneil RL, Sheng N, Strayhorn C, Fisher LW, Somerman MJ (1994): Bone sialoprotein is localized to the root surface during cementogenesis. J Bone Miner Res $\underline{9}$, 1597-1606

MacNeil RL, Berry J, D’Errico J, Strayhorn C, Somerman MJ (1995a): Localization and expression of osteopontin in mineralized and nonmineralized tissues of the periodontium. Ann N Y Acad Sci $\underline{760}$, 166-176

MacNeil RL, Berry J, D'Errico J, Strayhorn C, Piotrowski B, Somerman MJ (1995b): Role of two mineral-associated adhesion molecules, osteopontin and bone sialoprotein, during cementogenesis. Connect Tissue Res $\underline{33}, 1-7$

MacNeil RL, Berry J, Strayhorn C, Somerman MJ (1996): Expression of bone sialoprotein mRNA by cells lining the mouse tooth root during cementogenesis. Arch Oral Biol $\underline{41}, 827-835$

MacNeil RL, D'Errico JA, Ouyang H, Berry J, Strayhorn C, Somerman MJ (1998): Isolation of murine cementoblasts: unique cells or uniquely-positioned osteoblasts? Eur J Oral Sci 106 Suppl 1, 350-356

Malaval L, Wade-Guéye NM, Boudiffa M, Fei J, Zirngibl R, Chen F, Laroche N, Roux J-P, Burt-Pichat B, Duboeuf F, et al. (2008): Bone sialoprotein plays a functional role in bone formation and osteoclastogenesis. J Exp Med 205, 1145-1153

Malaval L, Monfoulet L, Fabre T, Pothuaud L, Bareille R, Miraux S, Thiaudiere E, Raffard G, Franconi J-M, Lafage-Proust M-H, et al. (2009a): Absence of bone sialoprotein (BSP) impairs cortical defect repair in mouse long bone. Bone $\underline{45}$, 853-861

Malaval L, Aubin JE, Vico L (2009b): Role of the small integrin-binding ligand Nlinked glycoprotein (SIBLING), bone sialoprotein (BSP) in bone development and remodeling. Osteoporos Int 20, 1077-1080 
Mariotti A (1993): The extracellular matrix of the periodontium: dynamic and interactive tissues. Periodontol $2000 \underline{3}, 39-63$

Marks SC, Schroeder HE (1996): Tooth eruption: theories and facts. Anat Rec $\underline{245}$, 374-393

Matias MA, Li H, Young WG, Bartold PM (2003): Immunohistochemical localization of fibromodulin in the periodontium during cementogenesis and root formation in the rat molar. J Periodontal Res $\underline{38}, 502-507$

Matthews BG, Roguljic H, Franceschetti T, Roeder E, Matic I, Vidovic I, Joshi P, Kum K-Y, Kalajzic I (2016): Gene-expression analysis of cementoblasts and osteoblasts. J Periodontal Res $\underline{51}$, 304-312

McAllister B, Narayanan AS, Miki Y, Page RC (1990): Isolation of a fibroblast attachment protein from cementum. J Periodontal Res $\underline{25}, 99-105$

McCauley LK, Somerman MJ: Mineralized Tissues in Oral and Craniofacial Science: Biological Principles and Clinical Correlates. Wiley-Blackwell, o.O. 2012

Meek RL, Bowman PD, Daniel CW (1977): Establishment of mouse embryo cells in vitro. Relationship of DNA synthesis, senescence and malignant transformation. Exp Cell Res 107, 277-284

Menanteau J, Neuman WF, Neuman MW (1982): A study of bone proteins which can prevent hydroxyapatite formation. Metab Bone Dis Relat Res $\underline{4}, 157-162$

Miki Y, Narayanan AS, Page RC (1987): Mitogenic activity of cementum components to gingival fibroblasts. J Dent Res $\underline{66}, 1399-1403$

Millan JL: Mammalian Alkaline Phosphatases: From Biology to Applications in Medicine and Biotechnology. Wiley-VCH-Verlag, Weinheim 2006

Minaříková M, Oralová V, Veselá B, Radlanski RJ, Matalová E (2015): Osteogenic Profile of Mesenchymal Cell Populations Contributing to Alveolar Bone Formation. Cells Tissues Organs 200, 339-348 
Monfoulet L, Malaval L, Aubin JE, Rittling SR, Gadeau AP, Fricain J-C, Chassande O (2010): Bone sialoprotein, but not osteopontin, deficiency impairs the mineralization of regenerating bone during cortical defect healing. Bone $\underline{46}, 447-452$

Mundlos S, Otto F, Mundlos C, Mulliken JB, Aylsworth AS, Albright S, Lindhout D, Cole WG, Henn W, Knoll JH, et al. (1997): Mutations involving the transcription factor CBFA1 cause cleidocranial dysplasia. Cell $\underline{89}, 773-779$

Nakamura M, Slots J (1983): Salivary enzymes. Origin and relationship to periodontal disease. J Periodontal Res $\underline{18}, 559-569$

Nanci A: Ten Cate's Oral Histology: Development, Structure, and Function. Mosby Elsevier, St. Louis 2008

Nanci A, Bosshardt DD (2006): Structure of periodontal tissues in health and disease. Periodontol $2000 \underline{40}, 11-28$

Narayanan AS, Ikezawa K, Wu D, Pitaru S (1995): Cementum specific components which influence periodontal connective tissue cells. Connect Tissue Res $\underline{33}, 19-21$

Nishimura K, Hayashi M, Matsuda K, Shigeyama Y, Yamasaki A, Yamaoka A (1989): The chemoattractive potency of periodontal ligament, cementum and dentin for human gingival fibroblasts. J Periodontal Res $\underline{24}, 146-148$

Nishimura K, Noguchi Y, Fukase Y, Suwa K, Yamaoka A, Yoshikawa E (1995): Effects of cementum-impregnated gelatine membrane on early healing following periodontal flap surgery. J Electron Microsc (Tokyo) 44, 91-99

Ogata Y, Yokota Y, Niisato N, Furuyama S, Sugiya H (1994): Presence of endogenous chemotactic factors for periodontal ligament cells in bovine cementum and bone. Arch Oral Biol 39, 529-533

Oldberg A, Franzén A, Heinegård D (1988): The primary structure of a cell-binding bone sialoprotein. J Biol Chem 263, 19430-19432

Olson S, Arzate H, Narayanan AS, Page RC (1991): Cell attachment activity of cementum proteins and mechanism of endotoxin inhibition. J Dent Res $\underline{70}, 1272-1277$ 
Orban B: Cementum. Oral Histology and Embryology. C.V. Mosby, St-Louis 1944

Orban B (1948): Clinical and histologic study of the surface characteristics of the gingiva. Oral Surg Oral Med Oral Pathol 1, 827-841

Otto F, Thornell AP, Crompton T, Denzel A, Gilmour KC, Rosewell IR, Stamp GW, Beddington RS, Mundlos S, Olsen BR, et al. (1997): Cbfa1, a candidate gene for cleidocranial dysplasia syndrome, is essential for osteoblast differentiation and bone development. Cell $\underline{89}, 765-771$

Ouyang H, McCauley LK, Berry JE, Saygin NE, Tokiyasu Y, Somerman MJ (2000): Parathyroid hormone-related protein regulates extracellular matrix gene expression in cementoblasts and inhibits cementoblast-mediated mineralization in vitro. J Bone Miner Res $\underline{15}$, 2140-2153

Page RC, Baab DA (1985): A new look at the etiology and pathogenesis of earlyonset periodontitis. Cementopathia revisited. J Periodontol $\underline{56}, 748-751$

Petersson U, Hultenby K, Wendel M (2003): Identification, distribution and expression of osteoadherin during tooth formation. Eur J Oral Sci 111, 128-136

Philbrick WM, Dreyer BE, Nakchbandi IA, Karaplis AC (1998): Parathyroid hormonerelated protein is required for tooth eruption. Proc Natl Acad Sci U S A 95, 1184611851

Pihlstrom BL, Michalowicz BS, Johnson NW (2005): Periodontal diseases. Lancet $\underline{366}, 1809-1820$

Pitaru S, Savion N, Hekmati H, Olson S, Narayanan SA (1993): Molecular and cellular interactions of a cementum attachment protein with periodontal cells and cementum matrix components. J Periodontal Res $\underline{28}, 560-562$

Pitaru S, McCulloch CA, Narayanan SA (1994): Cellular origins and differentiation control mechanisms during periodontal development and wound healing. J Periodontal Res $\underline{29}, 81-94$

Pitaru S, Narayanan SA, Olson S, Savion N, Hekmati H, Alt I, Metzger Z (1995): Specific cementum attachment protein enhances selectively the attachment and migration of periodontal cells to root surfaces. J Periodontal Res $\underline{30}, 360-368$ 
Poser JW, Price PA (1979): A method for decarboxylation of gamma-carboxyglutamic acid in proteins. Properties of the decarboxylated gamma-carboxyglutamic acid protein from calf bone. J Biol Chem 254, 431-436

Proff P, Römer P (2009): The molecular mechanism behind bone remodelling: a review. Clin Oral Investig $\underline{13}$, 355-362

Qin C, Baba O, Butler WT (2004): Post-translational modifications of sibling proteins and their roles in osteogenesis and dentinogenesis. Crit Rev Oral Biol Med 15, 126136

Quack I, Vonderstrass B, Stock M, Aylsworth AS, Becker A, Brueton L, Lee PJ, Majewski F, Mulliken JB, Suri M, et al. (1999): Mutation analysis of core binding factor A1 in patients with cleidocranial dysplasia. Am J Hum Genet $\underline{65}, 1268-1278$

Radlanski RJ: Orale Struktur- und Entwicklungsbiologie: (Curriculum). QuintessenzVerlag, Berlin [u.a.] 2011

Ram VS, Parthiban null, Sudhakar U, Mithradas N, Prabhakar R (2015): Bonebiomarkers in periodontal disease: a review article. J Clin Diagn Res $\underline{9}$, ZE07-10

Rao LG, Wang HM, Kalliecharan R, Heersche JN, Sodek J (1979): Specific immunohistochemical localization of type I collagen in porcine periodontal tissues using the peroxidase-labelled antibody technique. Histochem J 11, 73-82

Raymond MH, Schutte BC, Torner JC, Burns TL, Willing MC (1999): Osteocalcin: genetic and physical mapping of the human gene BGLAP and its potential role in postmenopausal osteoporosis. Genomics $\underline{60}, 210-217$

Reichardt LF, Tomaselli KJ (1991): Extracellular matrix molecules and their receptors: functions in neural development. Annu Rev Neurosci 14, 531-570

Reichert T, Störkel S, Becker K, Fisher LW (1992): The role of osteonectin in human tooth development: an immunohistological study. Calcif Tissue Int $\underline{50}, 468-472$

Robertson BW, Bonsal L, Chellaiah MA (2010): Regulation of Erk1/2 activation by osteopontin in PC3 human prostate cancer cells. Mol Cancer $\underline{9}, 260$ 
Romberg RW, Werness PG, Lollar P, Riggs BL, Mann KG (1985): Isolation and characterization of native adult osteonectin. J Biol Chem 260, 2728-2736

Romberg RW, Werness PG, Riggs BL, Mann KG (1986): Inhibition of hydroxyapatite crystal growth by bone-specific and other calcium-binding proteins. Biochemistry (Mosc) 25, $1176-1180$

Saffar JL, Lasfargues JJ, Cherruau M (1997): Alveolar bone and the alveolar process: the socket that is never stable. Periodontol $2000 \underline{13}, 76-90$

Sage EH, Bornstein P (1991): Extracellular proteins that modulate cell-matrix interactions. SPARC, tenascin, and thrombospondin. J Biol Chem 266, 14831-14834

Sakata M, Shiba H, Komatsuzawa H, Fujita T, Uchida Y, Yoshino H, Ogawa T, Kawaguchi H, Kurihara H (2002): Osteoprotegerin levels increased by interleukin1 beta in human periodontal ligament cells are suppressed through prostaglandin $\mathrm{E}(2)$ synthesized de novo. Cytokine $\underline{18}, 133-139$

Salmon CR, Tomazela DM, Ruiz KGS, Foster BL, Paes Leme AF, Sallum EA, Somerman MJ, Nociti FH (2013): Proteomic analysis of human dental cementum and

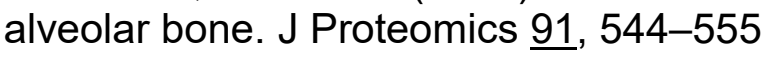

Samandari F, Mai JK: Curriculum funktionelle Anatomie für Zahnmediziner. Quintessenz-Verlag, Berlin [u.a.] 1995

Sasano Y, Maruya Y, Sato H, Zhu JX, Takahashi I, Mizoguchi I, Kagayama M (2001): Distinctive expression of extracellular matrix molecules at mRNA and protein levels during formation of cellular and acellular cementum in the rat. Histochem J $\underline{33}, 91-$ 99

Sato R, Yamamoto H, Kasai K, Yamauchi M (2002): Distribution pattern of versican, link protein and hyaluronic acid in the rat periodontal ligament during experimental tooth movement. J Periodontal Res $\underline{37}, 15-22$

Saygin NE, Giannobile WV, Somerman MJ (2000): Molecular and cell biology of cementum. Periodontol $2000 \underline{24}, 73-98$

Schroeder HE: Origin, Structure and Distribution of Cementum and its Possible Role in Local Periodontal Treatment. Karger Publishers, Basel 1988 
Schroeder HE: Orale Strukturbiologie: Entwicklungsgeschichte, Struktur und Funktion normaler Hart- und Weichgewebe der Mundhöhle und des Kiefergelenks. (Flexibles Taschenbuch- DENT). 4.,teilw. überarb. Auflage.; Thieme, Stuttgart [u.a.] 1992

Schroeder TM, Jensen ED, Westendorf JJ (2005): Runx2: a master organizer of gene transcription in developing and maturing osteoblasts. Birth Defects Res Part C Embryo Today $\underline{75}, 213-225$

Scivetti M, Pilolli GP, Corsalini M, Lucchese A, Favia G (2007): Confocal laser scanning microscopy of human cementocytes: analysis of three-dimensional image reconstruction. Ann Anat Anat Anz 189, 169-174

Selvig KA (1965): The fine structure of human cementum. Acta Odontol Scand $\underline{23}$, 423-441

Sequeira P, Bosshardt DD, Schroeder HE (1992): Growth of acellular extrinsic fiber cementum (AEFC) and density of inserting fibers in human premolars of adolescents. J Periodontal Res $\underline{27}, 134-142$

Shay JW, Wright WE, Werbin H (1991): Defining the molecular mechanisms of human cell immortalization. Biochim Biophys Acta 1072, 1-7

Shibata S, Yoneda S, Yanagishita M, Yamashita Y (2002): Developmental changes and regional differences in histochemical localization of hyaluronan and versican in postnatal molar dental pulp. Int Endod J $\underline{35}, 159-165$

Siggelkow H, Schenck M, Rohde M, Viereck V, Tauber S, Atkinson MJ, Hüfner M (2002): Prolonged culture of HOS 58 human osteosarcoma cells with 1,25-(OH)2D3, TGF-beta, and dexamethasone reveals physiological regulation of alkaline phosphatase, dissociated osteocalcin gene expression, and protein synthesis and lack of mineralization. J Cell Biochem 85, 279-294

Siggelkow H, Schmidt E, Hennies B, Hüfner M (2004): Evidence of downregulation of matrix extracellular phosphoglycoprotein during terminal differentiation in human osteoblasts. Bone $\underline{35}, 570-576$

Slavkin HC, Boyde A (1974): Cementum: an epithelial secretory product? J Dent Res $\underline{53}, 157$ 
Slavkin HC, Bringas P (1976): Epithelial-mesenchyme interactions during odontogenesis. IV. Morphological evidence for direct heterotypic cell-cell contacts. Dev Biol $\underline{50}, 428-442$

Slavkin HC, Bessem C, Fincham AG, Bringas P, Santos V, Snead ML, ZeichnerDavid M (1989): Human and mouse cementum proteins immunologically related to enamel proteins. Biochim Biophys Acta 991, 12-18

Sodek J, McKee MD (2000): Molecular and cellular biology of alveolar bone. Periodontol $2000 \underline{24}, 99-126$

Sodek J, Ganss B, McKee MD (2000): Osteopontin. Crit Rev Oral Biol Med 11, 279_ 303

Sodek J, Zhu B, Huynh M-H, Brown TJ, Ringuette M (2002): Novel functions of the matricellular proteins osteopontin and osteonectin/SPARC. Connect Tissue Res $\underline{43}$, 308-319

Somerman MJ, Archer SY, Shteyer A, Foster RA (1987): Protein production by human gingival fibroblasts is enhanced by guanidine EDTA extracts of cementum. $\mathrm{J}$ Periodontal Res $\underline{22}, 75-77$

Somerman MJ, Fisher LW, Foster RA, Sauk JJ (1988): Human bone sialoprotein I and II enhance fibroblast attachment in vitro. Calcif Tissue Int $\underline{43}, 50-53$

Sommer B, Bickel M, Hofstetter W, Wetterwald A (1996): Expression of matrix proteins during the development of mineralized tissues. Bone $\underline{19}, 371-380$

Sone S, Nakamura M, Maruya Y, Takahashi I, Mizoguchi I, Mayanagi H, Sasano Y (2005): Expression of versican and ADAMTS during rat tooth eruption. J Mol Histol $\underline{36}, 281-288$

Sunderkötter C, Steinbrink K, Goebeler M, Bhardwaj R, Sorg C (1994): Macrophages and angiogenesis. J Leukoc Biol $\underline{55}, 410-422$

Swaminathan R (2001): Biochemical markers of bone turnover. Clin Chim Acta Int J Clin Chem 313, 95-105 
Taba M, Jin Q, Sugai JV, Giannobile WV (2005): Current concepts in periodontal bioengineering. Orthod Craniofac Res $\underline{8}, 292-302$

Ten Cate AR: The development of the periodontium. In: Melcher AR, Bowen WH (Hrsg.): Biology of the periodontium. Academic Press, New York 1969, 53-90

Tenorio D, Hughes FJ (1996): An immunohistochemical investigation of the expression of parathyroid hormone receptors in rat cementoblasts. Arch Oral Biol $\underline{41}, 299$ 305

Tenorio D, Cruchley A, Hughes FJ (1993): Immunocytochemical investigation of the rat cementoblast phenotype. J Periodontal Res $\underline{28}, 411-419$

Termine JD, Kleinman HK, Whitson SW, Conn KM, McGarvey ML, Martin GR (1981): Osteonectin, a bone-specific protein linking mineral to collagen. Cell 26, 99105

Thomas HF (1995): Root formation. Int J Dev Biol 39, 231-237

van Bezooijen RL, Bronckers AL, Gortzak RA, Hogendoorn PCW, van der Wee-Pals L, Balemans W, Oostenbroek HJ, Van Hul W, Hamersma H, Dikkers FG, et al. (2009): Sclerostin in mineralized matrices and van Buchem disease. J Dent Res $\underline{88}$, 569-574

van Bezooijen RL, Roelen BAJ, Visser A, van der Wee-Pals L, de Wilt E, Karperien M, Hamersma H, Papapoulos SE, ten Dijke P, Löwik CWGM (2004): Sclerostin is an osteocyte-expressed negative regulator of bone formation, but not a classical BMP antagonist. J Exp Med 199, 805-814

Verheul HM, Hoekman K, Luykx-de Bakker S, Eekman CA, Folman CC, Broxterman HJ, Pinedo HM (1997): Platelet: transporter of vascular endothelial growth factor. Clin Cancer Res $\underline{3}, 2187-2190$

Villarreal-Ramírez E, Moreno A, Mas-Oliva J, Chávez-Pacheco JL, Narayanan AS, Gil-Chavarría I, Zeichner-David M, Arzate H (2009): Characterization of recombinant human cementum protein 1 (hrCEMP1): primary role in biomineralization. Biochem Biophys Res Commun 384, 49-54 
Wade-Gueye NM, Boudiffa M, Vanden-Bossche A, Laroche N, Aubin JE, Vico L, Lafage-Proust M-H, Malaval L (2012): Absence of bone sialoprotein (BSP) impairs primary bone formation and resorption: the marrow ablation model under PTH challenge. Bone $\underline{50}, 1064-1073$

Wang HM, Nanda V, Rao LG, Melcher AH, Heersche JN, Sodek J (1980): Specific immunohistochemical localization of type III collagen in porcine periodontal tissues using the peroxidase-antiperoxidase method. J Histochem Cytochem 28, 12151223

Wegner M (1999): From head to toes: the multiple facets of Sox proteins. Nucleic Acids Res 27, 1409-1420

Wight TN (2002): Versican: a versatile extracellular matrix proteoglycan in cell biology. Curr Opin Cell Biol $\underline{14}, 617-623$

Winkler DG, Sutherland MK, Geoghegan JC, Yu C, Hayes T, Skonier JE, Shpektor D, Jonas M, Kovacevich BR, Staehling-Hampton K, et al. (2003): Osteocyte control of bone formation via sclerostin, a novel BMP antagonist. EMBO J 22, 6267-6276

Wu D, Ikezawa K, Parker T, Saito M, Narayanan AS (1996): Characterization of a collagenous cementum-derived attachment protein. J Bone Miner Res 11, 686-692

Wuthier RE (1982): A review of the primary mechanism of endochondral calcification with special emphasis on the role of cells, mitochondria and matrix vesicles. Clin Orthop 219-242

Xiao ZS, Thomas R, Hinson TK, Quarles LD (1998): Genomic structure and isoform expression of the mouse, rat and human Cbfa1/Osf2 transcription factor. Gene 214 , 187-197

Xuan JW, Hota C, Chambers AF (1994): Recombinant GST-human osteopontin fusion protein is functional in RGD-dependent cell adhesion. J Cell Biochem $\underline{54}$, 247255

Xuan JW, Hota C, Shigeyama Y, D’Errico JA, Somerman MJ, Chambers AF (1995): Site-directed mutagenesis of the arginine-glycine-aspartic acid sequence in osteopontin destroys cell adhesion and migration functions. J Cell Biochem $\underline{57}, 680-690$ 
Yamamoto T, Hinrichsen KV (1993): The development of cellular cementum in rat molars, with special reference to the fiber arrangement. Anat Embryol (Berl) $\underline{188}$, $537-549$

Yamamoto T, Domon T, Takahashi S, Arambawatta AKS, Wakita M (2004): Immunolocation of proteoglycans and bone-related noncollagenous glycoproteins in developing acellular cementum of rat molars. Cell Tissue Res $\underline{317}$, 299-312

Yamamoto T, Hasegawa T, Yamamoto T, Hongo H, Amizuka N (2016): Histology of human cementum: Its structure, function, and development. Jpn Dent Sci Rev $\underline{52}$, 63-74

Yamashiro T, Wang X-P, Li Z, Oya S, Aberg T, Fukunaga T, Kamioka H, Speck NA, Takano-Yamamoto T, Thesleff I (2004): Possible roles of Runx1 and Sox9 in incipient intramembranous ossification. J Bone Miner Res $\underline{19}, 1671-1677$

Yamauchi S, Cheng H, Neame P, Caterson B, Yamauchi M (1997): Identification, partial characterization, and distribution of versican and link protein in bovine dental pulp. J Dent Res $\underline{76}, 1730-1736$

Yonemura K, Narayanan AS, Miki Y, Page RC, Okada H (1992): Isolation and partial characterization of a growth factor from human cementum. Bone Miner 18, 187-198

Zander HA, Hurzeler B (1958): Continuous cementum apposition. J Dent Res $\underline{37}$, 1035-1044

Zeichner-David M, Oishi K, Su Z, Zakartchenko V, Chen L-S, Arzate H, Bringas P (2003): Role of Hertwig's epithelial root sheath cells in tooth root development. Dev Dyn $\underline{228}, 651-663$

Zelzer E, Mamluk R, Ferrara N, Johnson RS, Schipani E, Olsen BR (2004): VEGFA is necessary for chondrocyte survival during bone development. Dev Camb Engl 131, 2161-2171

Zhao N, Nociti FH, Duan P, Prideaux M, Zhao H, Foster BL, Somerman MJ, Bonewald LF (2016a): Isolation and Functional Analysis of an Immortalized Murine Cementocyte Cell Line, IDG-CM6. J Bone Miner Res 31, 430-442

Zhao N, Foster BL, Bonewald LF (2016b): The Cementocyte-An Osteocyte Relative? J Dent Res $\underline{95}, 734-741$ 
Zhu W, Rawlins BA, Boachie-Adjei O, Myers ER, Arimizu J, Choi E, Lieberman JR, Crystal RG, Hidaka C (2004): Combined bone morphogenetic protein-2 and -7 gene transfer enhances osteoblastic differentiation and spine fusion in a rodent model. J Bone Miner Res $\underline{19}$, 2021-2032 


\section{Danksagung}

An dieser Stelle möchte ich nun die Gelegenheit ergreifen, um mich bei all den Menschen zu bedanken, die mich unterstützt haben und diese Arbeit erst möglich gemacht haben.

Mein besonderer Dank gilt zunächst Professor Miosge, der mir die Möglichkeit gab, Teil seiner Forschungsgruppe zu sein und in seinem Labor arbeiten zu können. Vor allem möchte ich mich aber bei inm für seine wissenschaftlichen Anregungen und Anleitungen, seine Diskussionsbereitschaft und vor allem für seine außerordentlich gute Betreuung bedanken.

Christa Bode danke ich für Ihre große Geduld, ihre Motivation und ihr Engagement, mit dem sie mich und andere Doktoranden stets bei der Laborarbeit betreut hat. Außerdem möchte ich mich gerne bei Dr. Gökhan Cingöz für die Hilfsbereitschaft bei der Beantwortung von methodischen, fachlichen und auch technischen Fragen bedanken. Dr. med. dent. Andrea Schubert will ich für die vielen motivierenden Worte danken. Ein besonderer Dank gilt außerdem noch Jérôme Janßen, der mir im Erlernen der Methoden und bei der Arbeit eine ausserordentlich große Hilfe war. Meiner Mitdoktorandin, Kommilitonin und vor allem guten Freundin Diana Dillschneider möchte ich ebenfalls meinen großen Dank für die Motivation, Unterstützung und für die vielen gemeinsamen Stunden im Labor, die mein Leben in jeglicher Hinsicht bereichert haben, aussprechen.

Eva Hautmann danke ich für das Korrekturlesen und für die damit verbundenen Anregungen. 